\title{
WestVirginiaUniversity
}

THE RESEARCH REPOSITORY @ WVU

Graduate Theses, Dissertations, and Problem Reports

2002

\section{Quantifying the impact of the WTO on Kuwait}

\author{
Reyadh Y. Faras \\ West Virginia University
}

Follow this and additional works at: https://researchrepository.wvu.edu/etd

\section{Recommended Citation}

Faras, Reyadh Y., "Quantifying the impact of the WTO on Kuwait" (2002). Graduate Theses, Dissertations, and Problem Reports. 1673.

https://researchrepository.wvu.edu/etd/1673

This Dissertation is protected by copyright and/or related rights. It has been brought to you by the The Research Repository @ WVU with permission from the rights-holder(s). You are free to use this Dissertation in any way that is permitted by the copyright and related rights legislation that applies to your use. For other uses you must obtain permission from the rights-holder(s) directly, unless additional rights are indicated by a Creative Commons license in the record and/ or on the work itself. This Dissertation has been accepted for inclusion in WVU Graduate Theses, Dissertations, and Problem Reports collection by an authorized administrator of The Research Repository @ WVU.

For more information, please contact researchrepository@mail.wvu.edu. 


\title{
Quantifying the Impact of the WTO on Kuwait
}

\author{
Reyadh Faras
}

\author{
Dissertation submitted to the \\ College of Business and Economics \\ at West Virginia University \\ in partial fulfillment of the requirements \\ for the degree of \\ Doctor of Philosophy \\ in \\ Economics
Subhayu Bandyopadhyay, Ph.D., Chair
Ronald Balvers, Ph.D.
Stratford Douglas, Ph.D.
Ming Hwang, Ph.D.
Ali Mansour, Ph.D.
Department of Economics
Morgantown, West Virginia 2002

Keywords: Kuwait, WTO, International Trade, Welfare

Copyright 2002 Reyadh Faras 


\title{
ABSTRACT \\ Quantifying the Impact \\ of the WTO on Kuwait
}

\author{
Reyadh Faras
}

The major contribution of this study is to quantify the economic impact of Kuwait's membership in the World Trade Organization (WTO) on supply, demand, welfare and terms of trade. A general equilibrium international trade model is used to obtain quantitative results. The model is theoretically static and based on the assumptions of perfect competition and constant returns to scale. However, it was estimated and simulated dynamically.

After specifying the model theoretically it is estimated empirically by linearizing the supply and demand equations that were obtained from solving the model analytically. The estimated model is used in a number of simulation exercises in each one a given agreement is analyzed and economic effects are measured.

The simulation exercises gave a number of results. First, the agreement on tariff reduction has a very small (positive) effect on Kuwait because tariff rates are already low, making any reductions to have insignificant effects. Second, the antidumping agreement has a larger (negative) effect since it corresponds to higher increase in the price of the importable good. Third, the decline in the world's price of the importable good as a result of globally implementing the WTO agreements has opposite effects but of the same magnitude to those of the antidumping agreement. Finally, the agreement on government procurement has the least effects since it increases exports only. 


\section{TABLE OF CONTENTS}

List of Tables . $\mathrm{V}$

List of Figures vi

\section{CHAPTER (1): INTRODUCTION}

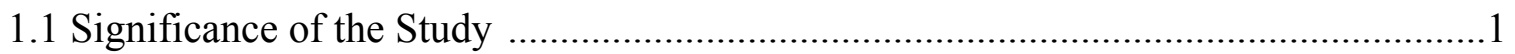

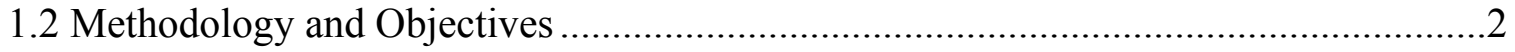

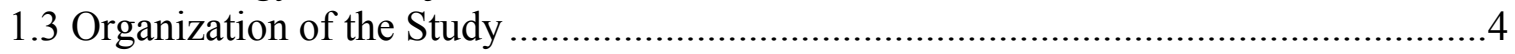

\section{CHAPTER (2): LITERATURE REVIEW}

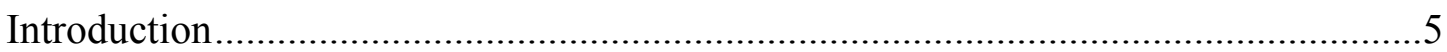

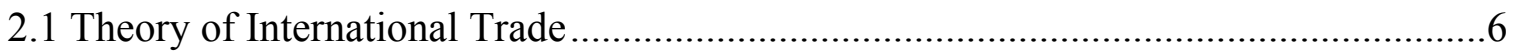

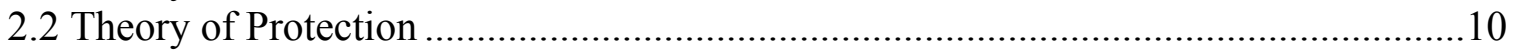

2.3 General Equilibrium Models................................................................................. 11

2.3.1 General Equilibrium Models Vs. Partial Equilibrium Models ............................13

2.3.2 General Equilibriu15m Models Vs. Macroeconometric Models..........................14

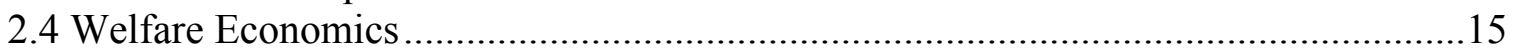

2.4.1 The Balance of Trade Function.....................................................................17

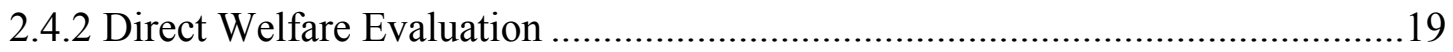

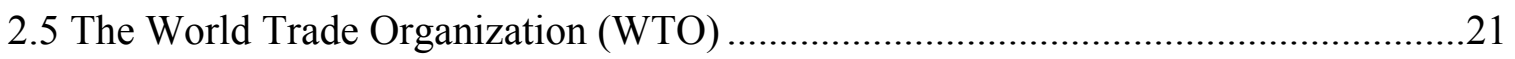

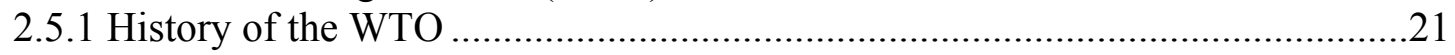

2.5.2 The WTO Agreements ............................................................................22

2.5.3 Empirical Assessment ...........................................................................25

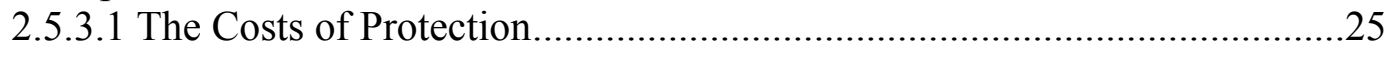

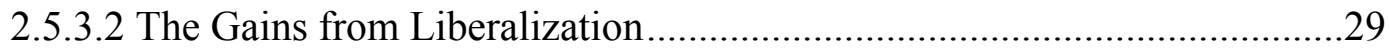

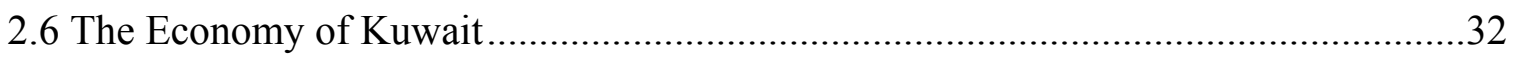

2.6.1 The Gross Domestic Product …………………….........................................32

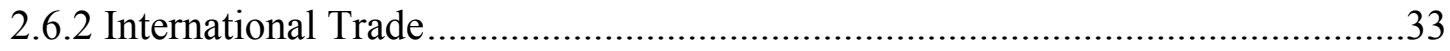

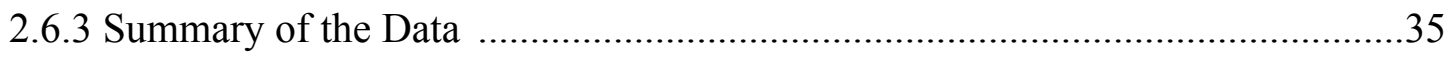

\section{CHAPTER (3): THE MODEL}

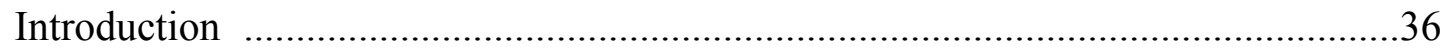

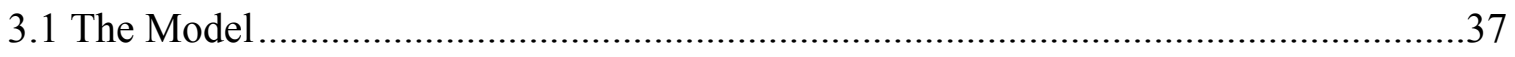

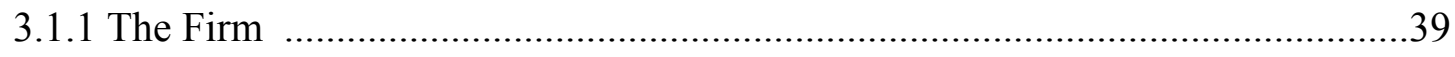

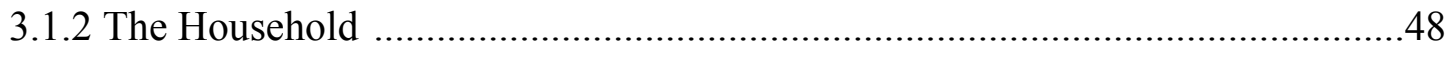

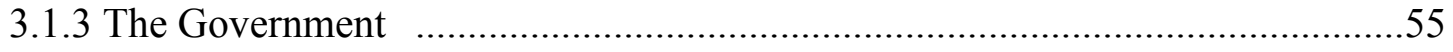

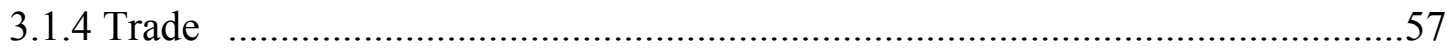




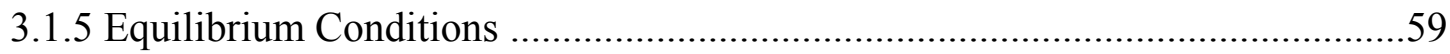

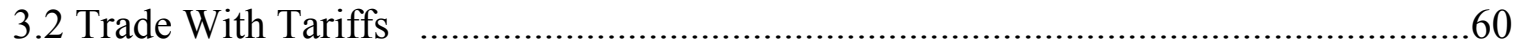

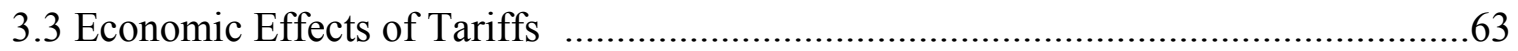

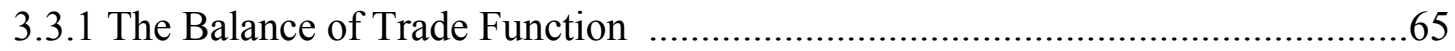

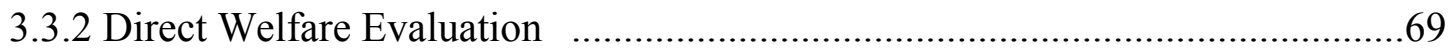

3.4 Economic Effects of Other WTO Agreements …….............................................72

\section{CHAPTER (4): ESTIMATION}

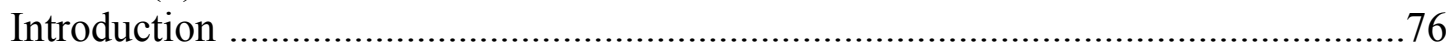

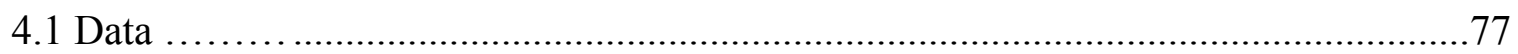

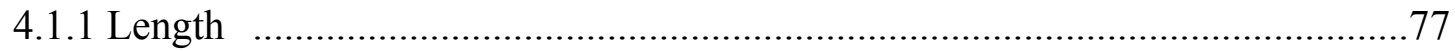

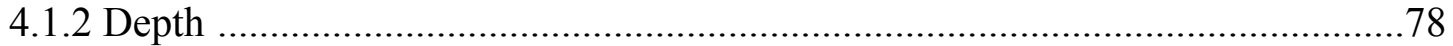

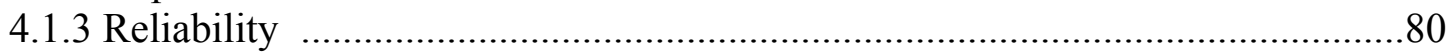

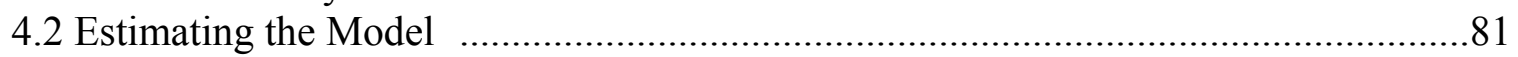

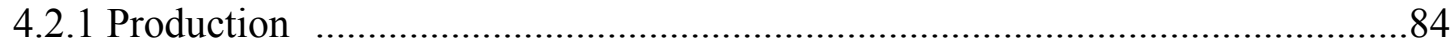

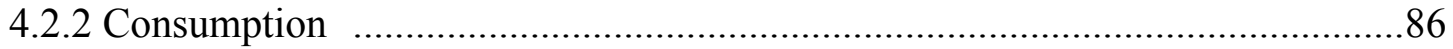

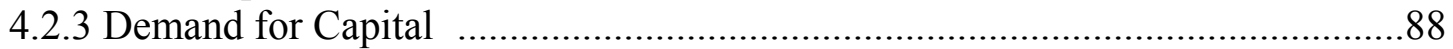

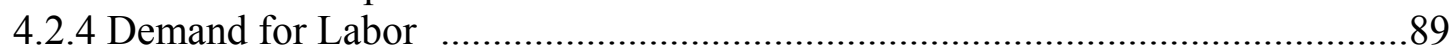

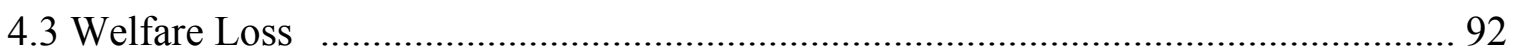

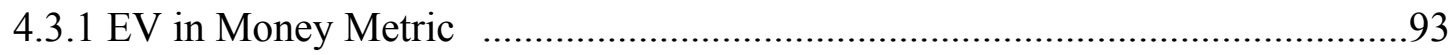

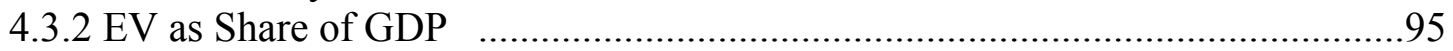

\section{CHAPTER (5): SIMULATION}

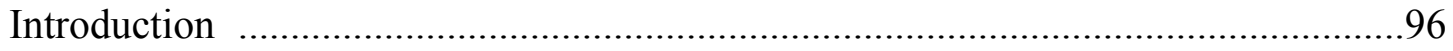

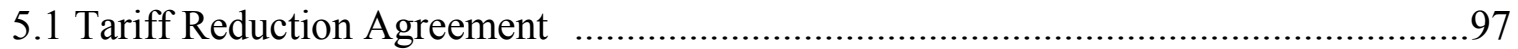

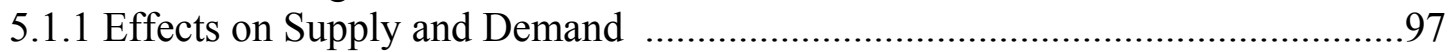

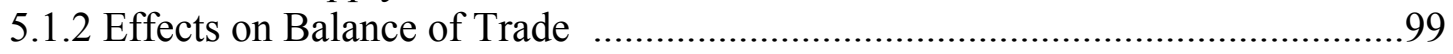

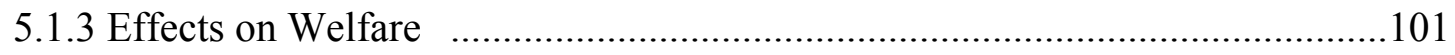

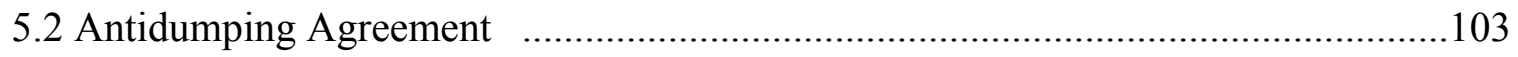

5.2.1 Effects on Supply and Demand ………………......................................104

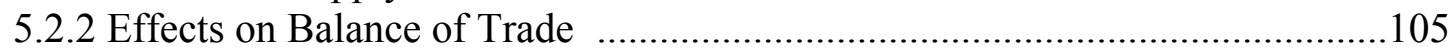

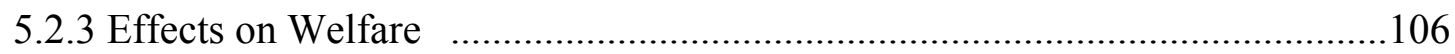

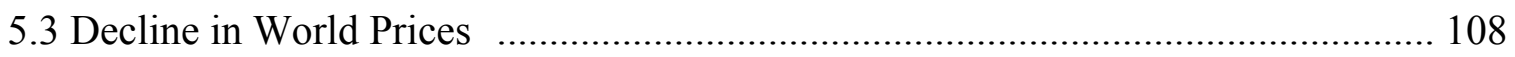

5.3.1 Effects on Supply and Demand ................................................................108

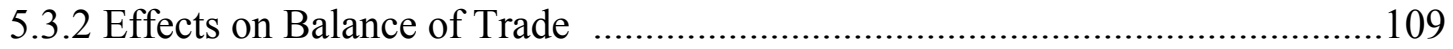

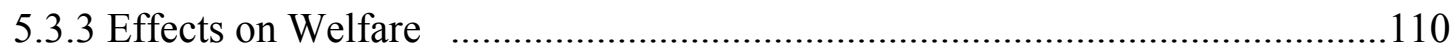

5.4 Government Procurement Agreement ……………............................................112 


\section{CHAPTER (6): CONCLUSIONS}

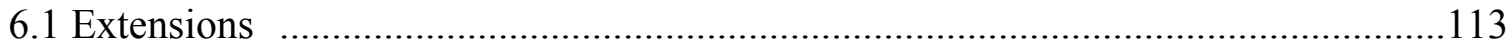

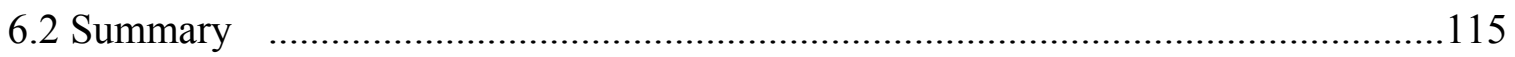

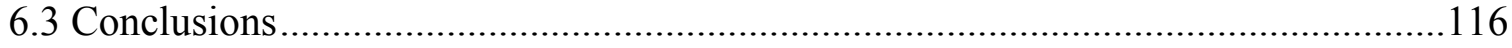

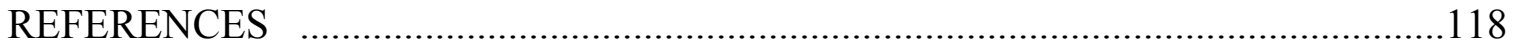

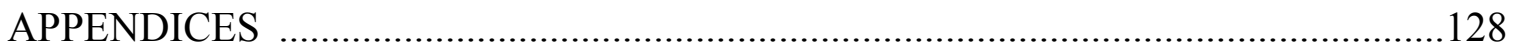




\section{LIST OF TABLES}

Table

1. Costs of Protection in Some OECD Countries .....................................................26

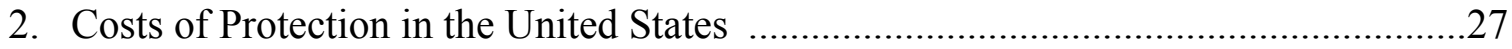

3. Costs of Saving Jobs in Some OECD Countries …...............................................29

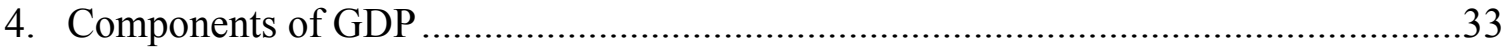

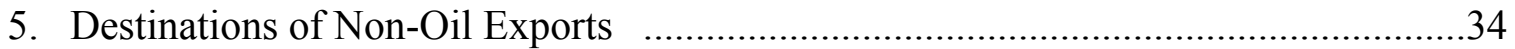

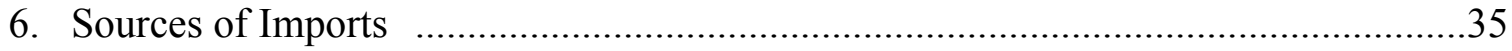

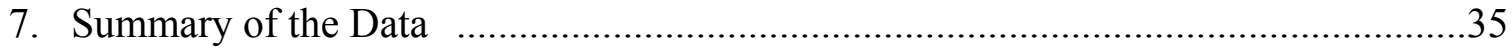

8. Equivalent Variation: Current Tariff Regime (in millions of KD) .........................93

9. Equivalent Variation: Current Tariff Regime (as percentage of GDP) ..................94

10. Effects on Supply and Demand: Tariff Reduction Agreement ...............................97

11. Effects on Balance of Trade : Tariff Reduction Agreement ................................99

12. Effects on Welfare $\quad$ : Tariff Reduction Agreement …..........................102

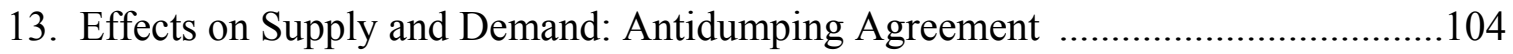

14. Effects on Balance of Trade : Antidumping Agreement …..............................105

15. Effects on Welfare : Antidumping Agreement ....................................106

16. Effects on Supply and Demand: Decline in World Prices .................................108

17. Effects on Balance of Trade : Decline in World Prices .....................................110

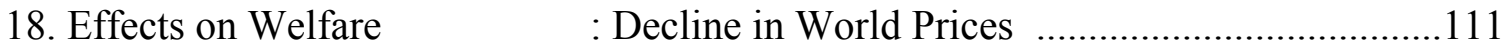

19. Effects on Balance of Trade : Government Procurement Agreement …...........112 
20. Summary of WTO Effects on Supply and Demand

21. Summary of WTO Effects on Supply and Demand

22. GATT Rounds and Value of Trade Covered

23. WTO Agreements 134

24. Survey of Time-Series Studies in LDCs 136

25. Survey of Time-Series Studies of Kuwait 137

26. Estimation of Supply and Demand: Baseline 138

27. Estimation of Supply and Demand: W/O Transfers and Oil Revenues 139 


\section{LIST OF FIGURES}

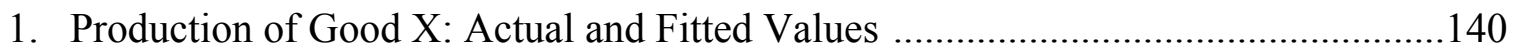

2. Production of Good Y: Actual and Fitted Values ..............................................141

3. Consumption of Good X: Actual and Fitted Values .......................................... 142

4. Consumption of Good Y: Actual and Fitted Values ............................................ 143

5. Demand for Capital in Sector X: Actual and Fitted Values ..................................144

6. Demand for Capital in Sector Y: Actual and Fitted Values ..................................145

7. Demand for Labor in Sector X: Actual and Fitted Values ....................................146

8. Demand for Labor in Sector Y: Actual and Fitted Values ...................................147

9. Production of Goods X: Baseline Vs. WTO Agreements......................................148

10. Production of Goods Y: Baseline Vs. WTO Agreements......................................149

11. Consumption of Good Y: Baseline Vs. WTO Agreements ...................................150

12. Consumption of Good X: Baseline Vs. WTO Agreements ..................................151

13. Demand for Capital in Sector X: Baseline Vs. WTO Agreements ..........................152

14. Demand for Capital in Sector Y: Baseline Vs. WTO Agreements ...........................153

15. Demand for Labor in Sector X: Baseline Vs. WTO Agreements ............................154

16. Demand for Labor in Sector Y: Baseline Vs. WTO Agreements ...........................155

17. Imports of Good Y: Baseline Vs. WTO Agreements ....................................... 156

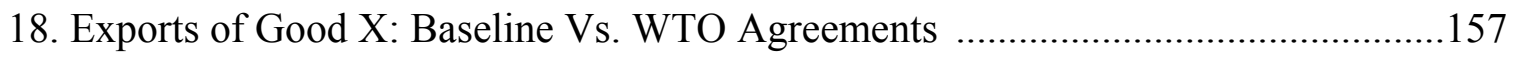




\section{CHAPTER (1)}

\section{INTRODUCTION}

\section{(1.1) SIGNIFICANCE OF THE STUDY}

The main purpose of this study is to quantify the economic impact of Kuwait's membership in the World Trade Organization (WTO). The dissertation will measure the possible effects to Kuwait of supply, demand, welfare and terms of trade as a result of the multilateral trade liberalization agreements signed at the end of the Uruguay Round which established the WTO on January 1, 1995. The WTO is expected to have significant effects on prices and exports for an enormous number of goods and services.

The Kuwaiti economy is a good case to be analyzed because it is a small, open, and developing economy. Therefore, it is interesting to see how it will respond to the potential changes in international trade.

The significance of this dissertation is that it is the first study to assess and quantify the effects of Kuwait's membership in the WTO. The quantitative results are important in guiding the government of Kuwait in its future trade policy initiatives. In addition, the results may be useful to many developing countries with characteristics similar to Kuwait's economy, in particular countries of the Gulf Cooperation Council (GCC). 


\section{(2.2) METHODOLOGY AND OBJECTIVES}

A general equilibrium international trade model is used to achieve the above goals. The model is static and based on the assumptions of perfect competition and constant returns to scale. The model describes the behavior of three representative economic agents ( a household, a firm and a government) in a small open economy. The firm produces two goods (using two factors: capital and labor) that it trades with a large foreign country. The first is an importable (i.e. in excess demand) good which corresponds to a bundle of manufactured goods (excludes capital goods, crude materials and agricultural products). The second is an exportable (i.e. in excess supply) good that represents a bundle of chemical goods. Thus, the excess supply and excess demand in the home country create a motive for international trade between the two countries. The government produces oil, which it exports to the foreign country, and produces services that are consumed domestically. The household consumes goods and services using income which comes from labor services supplied to the firm and the government and interest income on endowment of capital stock.

The model is specified to incorporate some of the WTO agreements that have direct effects on Kuwait. The first is the Multilateral Tariff Reduction Agreement which requires WTO members to reduce their import tariffs by a given percentage during a specified period. The second is the Antidumping Agreement which prohibits exporters from selling their goods at a foreign market at prices less than those in the exporter's market. The third is the Government Procurement Agreement which prohibits governments from favoring domestic suppliers to foreigners as a form of subsidizing 
domestic industries. The fourth is the Agreement on Subsidies and Countervailing Measures. This agreement prohibits governments from subsidizing domestic producers in a way that makes competition between domestic and foreign producers unfair. Finally, it will explore the effect of the expected decline in the world prices as a result of implementing the WTO agreements and the consequences of the reduction in trade barriers.

After specifying the model theoretically, it is estimated empirically using real annual data (in 1994 prices) for the period between 1969 and 1999. The main objective of estimating the model is to offer a quantitative measure of the above agreements on the Kuwaiti economy. The estimated model is used in conducting a number of simulation exercises where a given agreement is analyzed and economic effects is measured. In each simulation exercise the effects of the WTO is measured as the difference between the simulated values obtained under the current trade regime and the simulated values under a given agreement.

Finally, recommendations are made to assist the government and the private sector in maximizing the net benefits of joining the WTO. In addition, it is shown that the industrial sector needs to be restructured to make it more competitive in the new trade environment which will provide new opportunities for exports by improving the access of goods to the world market. On the other hand, this will impose new challenges by increasing competition in both prices and qualities. For example, public firms have to be privatized to increase their competitive ability and small firms have to be merged to take advantage of economies of scale. 


\section{(1.3) ORGANIZATION OF THE STUDY}

This study is organized as follows. Chapter (2) reviews the literature on both trade models and the WTO. The review includes a discussion of international trade theory, theory of protection, general equilibrium models used in international trade literature, welfare economics and the WTO literature. Chapter (3) presents the model that to be used in estimation and simulation. The chapter consists of four sections: the model's set up and derivation of demand and supply functions; international trade and trade policy; derivation of measures to quantify the economic effects of tariff's agreement; and the economic effects of other WTO agreements that have a direct effect on the economy of Kuwait. Chapter (4) is divided into three main sections: discussion of the data that are used and estimation technique; estimation of the demand and supply functions; and estimation of the welfare effects of the current tariff regime. Chapter (5) is based on simulations. It is divided into four main sections: analyzing the effects of Kuwait's enforcement of the tariff reduction agreement (assuming a reduction in import tariff rates by $25 \%$ ); analyzing the effects of enforcing the antidumping agreement (assuming an increase in world prices of the importable good by $10 \%$ ); analyzing the consequences of enforcing all of the WTO agreements (assuming a reduction in world prices of the importable good by 10\%); and finally, analyzing the effects of enforcing the agreement on government procurements (assuming that government purchases of domestic output are reduced by 50\%). Finally, chapter (6) presents the main conclusions of the study, proposes possible extensions and makes recommendations to assist the government and the private sector in maximizing the net benefits of joining the WTO. 


\section{CHAPTER (2)}

\section{LITERATURE REVIEW}

\section{INTRODUCTION}

This chapter reviews the literature on both trade models and the WTO.

In section (2.1) a review of the international trade theory is conducted with an emphasis on the Heckscher-Ohlin model. Section (2.2) is about the theory of protection where the main trade policy instruments are discussed. Section (2.3) presents the main characteristics of general equilibrium models that are commonly used in trade theory literature. Section (2.4) reviews the literature on welfare economics and the alternative measures of welfare loss of import tariffs and external shocks. Finally, section (2.5) gives a thorough presentation of the WTO literature. In section (2.5.1) a brief history of the WTO and the GATT is presented, while section (2.5.2) discusses some of the main agreements of the WTO. Section (2.5.3) surveys the literature on the costs of protection and the gains from the WTO and its effects on the world economy. 


\section{(2.1) THEORY OF INTERNATIONAL TRADE}

The origins of the theory of international trade go back to the early nineteenth century with the publication of the famous book by David Ricardo (1817); The Principles of Political Economy and Taxation. Ricardo built a trade model that he used to argue in favor of free trade and for the removal of the so called "Corn Laws" that restricted England's imports of food. The model was based on the idea of comparative advantage that arises from differences in labor productivity between countries. In the Ricardian model, labor is the only factor used in production. Relative efficiency in production results in specialization of each country in producing the goods in which it has a comparative advantage.

However, dissatisfaction with the Ricardian model in explaining trends in international trade as caused only by differences in labor productivity left trade theorists searching for a more satisfactory theory. Two Swedish Economists advanced a theory of international trade based on differences in resource abundance between countries. Heckscher (1949) and Ohlin (1933) came up with a theory that suggests that countries specialize in the production of goods that are intensive in a resource that is abundant in that country. The model gained increasing popularity by subsequent developments pioneered among others by Samuelson (1948). Since then, it has dominated the field of international trade as a general equilibrium approach to analyze trade barriers in competitive markets. 
The Hickscher-Ohlin (H-O) model is used in this study as a tool for analyzing the effects of changes in trade policy. What follows presents the set up and the main assumptions underlying the model.

The main features of the (H-O) two country model are as follows. Each economy is producing two goods ( $\mathrm{X}$ and $\mathrm{Y}$ ) using two factors of production (capital and labor) that are perfectly mobile between the two sectors but internationally immobile. Factor mobility is a cornerstone assumption in the model and is what distinguishes it from the Ricardian model of specific-factors (Vousden, 1990). Production technologies are identical across sectors and across countries. This implies that similar goods produced in different countries are identical (i.e. perfect substitutes) and therefore, are sold at a uniform price. In addition, the production technology exhibits constant returns to scale in the production of both goods. Markets for outputs and inputs are competitive. Households in the two countries have identical preferences and as a result, they have identical demand schedules for the two goods. Each economy spends no more than its income (i.e. expenditure equals income), which means that both countries have balanced trade (i.e. exports equal imports). Finally, countries only differ by the relative availability of resources. Resource availability is measured by the ratio of one input to the other (i.e. capital / labor).

Equilibrium in the model is achieved when total supply and total demand are equated, given the optimizing behaviors of the two representative economic agents. The representative consumer is maximizing a static, utility function subject to a budget constraint. The firm is maximizing profits subject to production technology. In the case 
of autarky (no trade) prices in the home country are determined where supply equals demand. Graphically (no graph provided), this corresponds to the point of tangency between the production possibilities curve and the "community's" indifference curve at a given price ratio.

With trade, however, prices are determined internationally by supply and demand forces in world markets. The opening of the economy to trade changes the relative price ratio and thus equilibrium (the tangency point) may differ from that of the autarky case. At this new equilibrium, domestic supply of either good does not necessarily equal demand. If the supply of a good, say X, exceeds domestic demand, then the excess supply is exported. Conversely, if the domestic demand for the other good, say Y, exceeds domestic supply, then the excess demand is imported. However, in total, where the balanced trade assumption must be maintained, expenditure equals income. Therefore, with trade, the economy can reach a higher indifference curve and be better off. In other words, trade is welfare improving.

To complete the presentation of the H-O model, it is necessary to talk about the issues of input prices, factor prices and factor intensity. First, a straightforward result from microeconomic theory is that a rise in the price of an input reduces the demand for that input by the two sectors. Second, a rise in the relative price of a product shifts resources to its production and results in an increase in the return to the factor that it uses intensively. This result is readily understood by noting that excess demand will occur for the input used intensively in producing the good whose price has risen because fewer 
amounts of this input have been released from the other sector. This conclusion is known as the Stolper-Samuelson Theorem:

A rise in the relative price of a good results in an increase in the real return of the input used more intensively in its production and a decline in the real return to the other input.

Third, the issue of factor intensity has an essential role in the H-O model. As stated earlier, an economy will specialize in the production of the good that uses an input that is relatively abundant in that economy. This leads to an important theorem in the HO model, the Rybcznski's Theorem. This theorem is stated as follows:

An increase in the endowment of one factor, ceteris paribus, increases the production of the good that uses this factor more intensively and reduces the production of the other good. 


\section{(2.2) THEORY OF PROTECTION}

International trade theorists have made remarkable progress in advancing and developing the theory of protection that explains, evaluates and quantifies economic effects of trade barriers. Among the most influential Economists that advanced this theory are Bhagwati, Corden, Kemp and Johnson. When trade barriers are mentioned, the first thing that comes to mind is the import tariff. Tariffs are just one instrument that countries use to influence the flow of trade in and out of their countries. Trade barriers include an array of instruments that is discussed briefly below.

Import tariffs: Import tariffs are the oldest and most popular trade policy instrument ever used. Countries commonly use tariffs to reach either or both of two goals- raising government revenues, and protecting domestic industries from competition. The former goal has lost its importance in the last century, as other sources of income have become available to governments (e.g. domestic taxes on income, consumption, and business). The latter, however, is still a popular policy instrument used by many countries especially less developed countries (LDCs). Developed countries, on the other hand, have reduced their reliance on tariffs for protection purposes but resorted to other policies that is discussed below. Tariffs have the ability to distort the flow of international trade by altering the relative prices facing consumers and producers, therefore deviating the economy away from the pareto optimal equilibrium reached by free trade. In the next chapter, section (3.2) discusses the effects of tariffs in greater detail.

Import quotas: In the second half of the last century, many developed countries have reduced their reliance on tariffs in favor of import quotas. Import quotas have the 
same effects as tariffs because, when they are binding, they cause the relative price of the importable good to increase. The only difference between the two, tariffs and quotas, is that the foreign country is the only beneficiary of the price increase in the case of quotas, while the government is the only beneficiary of the price increase in the case of tariffs.

Export subsidies: Export subsidies are aimed at promoting exports and are common in both LDCs (e.g. subsidies to manufacturing exports) and developed countries (e.g. subsidies to agricultural exports). These subsidies result in reducing export prices and increasing the volume of exports (i.e. increasing competitiveness), while reducing supply and increasing prices in the domestic market. One main difference between export subsidies and import tariffs is that the former puts a fiscal burden on the government/taxpayers, while the latter provides revenues.

Production subsidies: Production subsidies are intended to expand domestic production and reduce imports of the importable good. These subsidies differ from export subsidies by not distorting domestic prices and thus, not affecting domestic demand. One more difference is that these subsidies apply to a larger volume of output and, as a result, have a bigger fiscal burden.

The above are the main trade policy instruments used by governments to protect their domestic industries. The welfare effects of these instruments is discussed in section (2.4). 


\section{(2.3) GENERAL EQUILIBRIUM MODELS}

International trade models in general and the Hickscher-Ohlin model in particular use General Equilibrium (GE) models in explaining the flow in trade between countries and measuring their effects on economies. The GE models are preferable to other models such as partial equilibrium and macroeconometric models. Comparisons between the GE model and its alternatives is presented in subsections (2.3.1 and 2.3.2) after discussing the main features of the GE model below.

General equilibrium models were formalized by the work of Arrow and Debreu (1954, 1959), Scarf (1967, 1973) and Arrow and Hahn (1971) and are based on Walras' Law that all markets clear in equilibrium. Interaction between markets is the cornerstone of GE models. Since the 1960s, GE models have become essential tools in two fields of economics; public finance and international trade. In trade literature, GE models have become, almost, the only tool in both single-country and multi-country models due to the pioneering works of trade theorists, such as James Meade and Harry Johnson, in the period between the fifties and the seventies.

A typical GE model consists of two sectors producing two goods using two factors of production. The behavior of the economy is characterized by the behavior of two representative agents, a household and a firm. Equilibrium is reached by the optimizing behaviors of the two agents which results in equating demand to supply, due to Walras' Law. A major step was taken in the development of GE models by converting the theoretical models into applied models that can be used empirically in evaluating trade policies and external shocks. Applying GE models consists of three main stages. In 
the first, market structure and functional forms for utility and production functions are specified, while in the second stage the model is solved numerically using actual data. Because GE models are large and nonlinear by nature, they are difficult to solve analytically. Alternatively, a common technique used to solve GE models numerically is called calibration. Calibration involves using one year's data as a benchmark and parameters are taken as given (from other studies), instead of estimating them within the model as in macroeconometric models. These parameters are used to generate baseline estimates that are used in the third stage in producing counterfactual estimates that reflect policy changes or external shocks.

A more detailed discussion of GE models is presented in chapter (3) when the GE model for this study is presented. The next two subsections will compare GE models with two other popular models, partial equilibrium and macroeconometric models.

\section{(2.3.1) GE MODELS VS. PARTIAL EQUILBRIUM MODELS}

By definition, partial equilibrium (PE) models deal with more limited details of the economy than general equilibrium models. A typical PE model is used in estimating the effects of a change in one variable on another variable or on a few variables. In contrast to a GE model, a PE model assumes that markets are segregated and therefore ignores possible interactions between markets that may affect supply, demand and relative prices. In addition, a GE model gives more reliable results than a PE model, 
which may yield erratic and approximate results (Whalley, 1975). In trade literature, the use of a PE model in estimating the effects of a change in a trade policy (e.g. tariffs) would underestimate the effects of the policy change since it ignores the effects on relative prices that are more likely to affect supply, demand, real returns to factors of production, and resource allocation ( Bandara, 1991).

\section{(2.3.2) GE MODELS VS. MACROECONOMETRIC MODELS}

Until the early 1970s, macroeconometric models have worked well and were widely used. However, they lost their popularity in the mid seventies due to two main factors. First, the period of stagflation during which these models performed poorly when they were used to generate economic forecasts. The second factor was the criticism by Robert Lucas (1976) who criticized macroeconometric models because of their lack of microeconomic foundations. This was known as "Lucas Critique," which simply states that parameters estimated using macroeconometric models cannot be used for forecasting the effects of future economic policies since the parameters will change when policy changes, because economic agents will adjust their behavior given their expectations of future policies.

Since then, GE models have gained much of their popularity because of their strong theoretical foundations stemming from microeconomic theory. In other word, they avoided the "Lucas Critique." GE models also have the advantage of their flexibility to be applied to most economic fields and in evaluating a large number of policy changes and economic shocks. 


\section{(2.4) WELFARE ECONOMICS}

Mishan (1960, p.199) defines welfare economics as "that branch of study which endeavors to formulate propositions by which we may rank, on the scale of better or worse, alternative economic situations open to society". The most important words in this definition are better and worse. Welfare loss/gain is the main criterion by which we evaluate a given project, tax system or trade policy. Welfare loss (also known in the Public Finance literature as the excess burden) is the difference between the reduction in consumption due to a public policy (e.g. tariff or tax) and what the government actually collects. The tool commonly used in determining the welfare loss/gain is the consumer surplus: the difference between what the consumer is willing to pay for a good and the actual price paid. The consumer surplus can be defined in two ways. First, the Marshallian consumer surplus corresponds, graphically, to the area to the left of the uncompensated demand curve above the price. Second, the Hicksian consumer surplus corresponds to the area to the left of the compensated demand curve above the price. However, empirically the Marshallian consumer surplus is rarely used for two main reasons. First, it is not derived from the consumer's optimizing behavior (Auerbach and Feldstein, 1985) and thus, lacks theoretical foundations (Martin, 1997). Second, it provides only an approximation for the welfare effect (Martin, 1997). Therefore, it will not be discussed in this study. The Hicksian consumer surplus is commonly derived from general equilibrium models, this gives it the advantage of being a measure of the welfare of all representative agents and takes into account feedbacks between the different markets. 
This leaves us with the Hicksian surplus measures. Hicks (1942) has come up with two measures of consumer surplus that are based on the compensated demand function. This function is based on the idea that to keep the consumer's utility constant, income must change in a way that compensates him for the change in price (Varian, 1992). The first measure is the Compensating Variation (CV), which is defined as the amount of income the consumer must receive to keep his utility unaffected by the price change. The second measure is the Equivalent Variation (EV), which is defined as the amount of income the consumer is willing to give up in order to avoid the change in price. Because of their precise measure of consumer surplus, the EV and CV have become the main tools used in the international trade literature in evaluating trade policies, trade agreements and internal/external shocks [Harris (1984), Trela and Whalley (1990), Brown and Whalley (1980), and Nguyen, Perroni and Wigle (1993)].

The $\mathrm{CV}$ and EV can be derived in two different ways that both give the same measure of welfare in the absence of distortions (Martin, 1997). Interestingly, the two approaches, also, depend on the expenditure function, $\mathrm{E}(\mathrm{P}, \mathrm{U})$. The expenditure function is defined as the minimum expenditure required to reach the level of utility (U) at the given price $(\mathrm{P})$. The expenditure function is widely used in public finance (for example: Small and Rosen, 1980; Kay, 1980; Diamond and McFadden, 1974 and Dixit, 1975) and in international trade (for example: Martin and Alston, 1994; Lloyd and Schweinberger, 1988 and Tyers and Falvey, 1989). The first approach is known as the balance of trade function and the second is known as the direct welfare evaluation approach. Below is a brief presentation of the two approaches based on Martin's (1997) comparison of the two 
approaches. The derivation of the two approaches is saved for the next chapter (section 3.3) where we derive the welfare measures algebraically.

\section{(2.4.1) THE BALANCE OF TRADE FUNCTION}

The balance of trade approach is based on the balance of trade condition and can be derived from the income-expenditure identity:

$$
E(p, w, u)-R(p, w, v)-\left(p-p^{*}\right) Z_{p}(p, w, v, u)-f=0
$$

Where $\mathrm{E}(\mathrm{p}, \mathrm{w}, \mathrm{u})$ is the expenditure function, $\mathrm{R}(\mathrm{p}, \mathrm{w}, \mathrm{v})$ is the national revenue function (i.e. GDP), $\mathrm{Z}_{\mathrm{p}}(\mathrm{p}, \mathrm{w}, \mathrm{v}, \mathrm{u})$ is imports $\left(\mathrm{Z}_{\mathrm{p}}=\mathrm{E}_{\mathrm{p}}-\mathrm{R}_{\mathrm{p}}\right)$ [subscript $\mathrm{p}$ is the derivative of $\mathrm{Z}$ with respect to $p], p^{*}$ is world price, $p$ is domestic price, $w$ are factor prices, $v$ are inputs and $f$ is net financial inflow from abroad.

The above identity states that expenditure $(\mathrm{E}(\mathrm{p}, \mathrm{w}, \mathrm{u}))$ must equal income (GDP + tariff revenues $+\mathrm{f}$ ). This implies, as mentioned in section (2.1), that trade must be balanced. The balance of trade function has the ability to incorporate a number of internal and external distortions, in addition to tariffs, that have a direct effect on social welfare (e.g. domestic taxes, changes in world prices, export subsidies and import quotas). Utility in the income-expenditure identity is endogenous, while prices, resource endowments (v) and financial inflow (f) are exogenous.

Following Anderson and Neary (1992), the balance of trade function can be derived from equation (1) by assuming that utility is exogenous and by adding a new term (B) that measures the additional (f) that keeps the level of utility fixed:

$$
B^{i}\left(p, p^{*}, w, v, u^{i}\right)=Z\left(p, w, v, u^{i}\right)-\left(p-p^{*}\right) Z_{p}\left(p, v, u^{i}\right)-f
$$


In equation $(2),\left(u^{i}\right)$ can be defined either as the initial level of the exogenous utility if we use the Compensating Variation measure or as the final level of utility if the Equivalent Variation measure is used. Thus, $\left(\mathrm{B}^{\mathrm{i}}\right)$ is defined as a measure of welfare change at $\left(\mathrm{u}^{\mathrm{i}}\right)$ and can be used to find both $\mathrm{CV}$ and $\mathrm{EV}$ of a change in world price from $\mathrm{p}_{0}{ }^{*}$ to $\mathrm{p}_{1}{ }^{*}$.

$\mathrm{CV}: \mathrm{B}_{1}{ }^{0}-\mathrm{B}_{0}{ }^{0}=\mathrm{B}\left[\mathrm{p}_{1}, \mathrm{w}_{1}, \mathrm{p}_{1}{ }^{*}, \mathrm{v}, \mathrm{u}^{0}\right]-\mathrm{B}\left[\mathrm{p}_{0}, \mathrm{w}_{0}, \mathrm{p}_{0}{ }^{*}, \mathrm{v}, \mathrm{u}^{0}\right]$

$$
=\mathrm{B}\left[\mathrm{p}_{1}, \mathrm{w}_{1}, \mathrm{p}_{1}{ }^{*}, \mathrm{v}, \mathrm{u}^{0}\right]
$$

because $\mathrm{B}\left[\mathrm{p}_{0}, \mathrm{w}_{0}, \mathrm{p}_{0}{ }^{*}, \mathrm{v}, \mathrm{u}^{0}\right]=0$ by equation (1).

$\mathrm{EV}: \mathrm{B}_{1}{ }^{1}-\mathrm{B}_{0}{ }^{1}=\mathrm{B}\left[\mathrm{p}_{1}, \mathrm{w}_{1}, \mathrm{p}_{1}{ }^{*}, \mathrm{v}, \mathrm{u}^{1}\right]-\mathrm{B}\left[\mathrm{p}_{0}, \mathrm{w}_{0}, \mathrm{p}_{0}{ }^{*}, \mathrm{v}, \mathrm{u}^{1}\right]$

$$
=-\mathrm{B}\left[\mathrm{p}_{0}, \mathrm{w}_{0}, \mathrm{p}_{0}{ }^{*}, \mathrm{v}, \mathrm{u}^{1}\right]
$$

because $\mathrm{B}\left[\mathrm{p}_{1}, \mathrm{w}_{1}, \mathrm{p}_{1}{ }^{*}, \mathrm{v}, \mathrm{u}^{1}\right]=0$ by equation (1).

The two measures above provide an exact measure of compensation required to keep utility fixed at $\left(\mathrm{u}^{\mathrm{i}}\right)$ as a result of a change in either world price, domestic price or tariff rates. However, Anderson and Martin (1995) show that the EV measure has the advantage of providing a money metric measure in addition to the compensation measure, while the CV provides only the latter. This makes the EV widely used in empirical studies in general and studies evaluating the welfare effects of the WTO in particular. 


\section{(2.4.2) DIRECT WELFARE EVALUATION}

An alternative measure of welfare change that is commonly used in general equilibrium models is the direct money metric measure that can be obtained from the expenditure and utility functions specified in GE models. Similar to the balance of trade function approach, the direct money metric approach can be used to get a measure of welfare in the form of either the equivalent variation or the compensating variation.

Both measures, $\mathrm{EV}$ and $\mathrm{CV}$, are specified as the difference between the expenditure functions evaluated at the initial prices, as in the EV, or at the new prices, as in the CV:

$\mathrm{EV}=\mathrm{E}\left(\mathrm{p}_{0}, \mathrm{u}_{0}\right)-\mathrm{E}\left(\mathrm{p}_{0}, \mathrm{u}_{1}\right)$

$\mathrm{CV}=\mathrm{E}\left(\mathrm{p}_{1}, \mathrm{u}_{0}\right)-\mathrm{E}\left(\mathrm{p}_{1}, \mathrm{u}_{1}\right)$

The above measures can be directly estimated from the household optimization problem as follows. First, minimize the expenditure of the household subject to keeping its utility fixed at a given level. This gives the Hicksian (compensated) demand functions. Second, plug these demand functions into the budget constraint, this gives the expenditure function.

Since both measures, EV and $\mathrm{CV}$, use different prices in evaluating welfare change, we expect their estimates not to be exact but at the same time there won't be a big difference between them. However, choosing either measure is of some importance and depends on the objectives of the researcher. Varian (1992) explains that if the goal is to provide a compensation scheme at new prices, then the $\mathrm{CV}$ is the appropriate choice, while if the goal is to obtain a measure of the willingness to pay, then the EV is more appropriate. Moreover, Varian argues in favor of the EV for two reasons. First, it is much 
easier to make decisions about proposed policies based on actual prices than hypothetical prices. Second, in the case of comparing more than one policy change, the EV keeps prices fixed at the status quo, while the $\mathrm{CV}$ uses different base prices for each policy. 


\section{(2.5) THE WORLD TRADE ORGANIZATION (WTO)}

Since the main objective of this study is to measure the economic effects of the WTO agreements, it is necessary to give an overview of the main issues surrounding the WTO. In this section we emphasize three issues that are discussed in the next three subsections.

\section{(2.5.1) HISTORY OF THE WTO}

Three historical factors have participated in the creation of the General Agreement on Tariffs and Trade (GATT), which preceded the WTO. First, the recognition by the world leaders that mistakes in economic policy during the interwar period (1920-1940) have, among other reasons, led to World War II (Jackson, 1998). Second, the passage of the 1934 Reciprocal Trade Agreement Act that allowed the United States' (hereafter US) President to enter into trade agreements to reduce tariffs. Under this act, the US has signed 32 bilateral tariff reduction agreements by 1945 . Drafts of these agreements have become the underlying versions of the GATT agreements. Finally, the Bretton Woods conference, which was held in 1944 and established the International Monetary Fund and the World Bank, has recognized the need for an international institution for trade to accompany the monetary institutions.

The first meeting of the GATT was held in Geneva in 1947 under the leadership

of the US and its allies (22 countries) to achieve two goals. First, discussing reciprocal agreements for tariff reductions and second to prepare for the creation of a new international trade institution that was to be called the International Trade Organization 
(ITO). Nevertheless, the refusal of the US Congress to pass a bill creating the ITO has prevented it from being established. Instead negotiations were carried out under the GATT as a treaty, not an institution. Since then, eight negotiating rounds were held between 1947 and 1994. The last round, the Uruguay Round (1986-1994), was the most successful one in terms of the number of participants (120 countries) and the scope and number of agreements reached (24 agreements). Table (22) in Appendix (3) presents the eight rounds and the volume of trade covered under each one. For example, trade covered by negotiations has tremendously increased from $\$ 2.5$ billion in the first round to $\$ 3,700.00$ billion in the Uruguay Round. The Uruguay round agreements were signed in Marrakesh in April 1994 and entered into force in January 1995 with the creation of the WTO. The main difference between the GATT and the WTO is the institutional charter of the latter, which gives it the authority to enforce the signed agreements.

\section{(2.5.2) THE WTO AGREEMENTS}

Earlier agreements reached by GATT negotiating rounds covered tariff reduction in trade in goods only, but the Uruguay round agreements covered new areas of trade, protection policies, environment, intellectual property rights, health and dispute settlement procedures. Table (23) in Appendix (4) summarizes all the agreements. Below is a brief discussion of some of the most important agreements. 
1. The General Agreement on Tariffs and Trade 1994

This agreement replaced the original agreement of the GATT that was signed in 1947. However, the new agreement has carried out most of the provisions of the old agreement, the main concern of which was tariff reduction. The new agreement required tariff reduction by $36 \%$ (24\%) by developed (developing) countries over a ten (fifteen) year period.

2. The Agreement on Textiles and Clothing

This agreement was a great achievement for developing countries producing textiles and clothing. Since 1974, textile exports from developing countries to developed countries were constrained by a system of quota restrictions enforced by the Multifibre Arrangement (MFA). This agreement requires a gradual removal of the MFA over a ten year period. The significance of this agreement is that it improves the market access for exports from developing countries that have a comparative advantage in producing textiles and clothing, which is a labor intensive industry.

3. The Agreement on Agriculture

Agriculture was a new area of trade in the Uruguay round. The agriculture agreement was also an achievement for developing countries exporting agricultural products because it improved their access to developed countries' markets. The agreement has four main features. First, reduction in import tariffs similar to that of manufactured goods. Second, a reduction in export subsidies by the same percentages as import tariffs and a reduction in domestic support by $20 \%(13 \%)$ for developed (developing) countries. Third, market access commitments were set at 3\% of domestic 
consumption at the beginning of the implementation period and to be increased to $5 \%$ by the year 2000 (2004) for developed (developing) countries. Finally, all non-tariff barriers (NTBs) have to be converted into tariff equivalents.

4. The Agreement on Subsidies and Countervailing Measures

This agreement prohibits government's financial contributions to a specific firm, industry or region that give them an advantage over foreign suppliers. These contributions (subsidies) fall into two categories. Export subsidies based on export performance and import substitution subsidies are based on the use of domestic goods instead of imports. The reason for the prohibition of subsidies is because they put domestic (subsidized) and foreign goods at an unfair competition.

5. The Antidumping Agreement

According to the WTO (1999a p.80) definition, dumping is "the sale of an exported product in a foreign market at a price below that at which the same product is usually sold in its home market". Unlike subsidies, dumping is performed by individual firms, this makes it difficult to be monitored, controlled or enforced by agreements between governments (WTO,1999a). The enforcement of this agreement requires two conditions: a proof of dumping and a proof of injury to domestic industry. If these two conditions were met, then the affected country may take one or more of the following measures: impose an antidumping duty, take provisional antidumping measures, or settle the price issue voluntarily by asking the exporter to revise its price. 
6. The Agreement on Trade in Services

This is the first agreement in services that was reached by the eight GATT negotiation rounds and it is considered the major development in GATT history. The agreement covers 150 different forms of services. These services are divided into 12 sectors among which are: financial services, telecommunications, transportation, health, education, tourism, and construction/engineering services.

7. The Agreement on Government Procurement

This agreement covers government purchases of goods and services. It prohibits governments from using their purchases as a mean of supporting domestic producers and discriminating against foreign suppliers. It should be noted that this agreement is one of the four voluntary agreements (known as "Plurilateral Agreements") and applies only to members who choose to sign it.

\section{(2.5.3) EMPIRICAL ASSESSMENT}

This subsection reviews review the empirical literature on the costs of protection and the gains from trade liberalization. An overview of the costs and benefits of trade policies is important in guiding an understanding of the gains from implementing the WTO agreements when the empirical findings are presented in chapter five. Subsection (2.5.3.1) presents a summary of empirical results of the negative effects of protectionist policies in some of the countries of the Organization for Economic Cooperation and Development (OECD). Subsection (2.5.3.2) presents empirical results of studies that 
were conducted in the 1990s to assess the potential gains from implementing the agreements that were signed by the end of the Uruguay round in 1994.

\section{(2.5.3.1) THE COSTS OF PROTECTION}

Three survey studies by Feenstra (1992), Hufbauer (1996) and the OECD (1998) provide an overall and detailed estimate of the costs of protection in OECD countries. Costs were expressed in terms of higher prices, costs of subsidies and costs of protecting jobs in the protected sectors of the economy. First, we present the OECD survey results of the costs of higher prices and subsidies in table (1).

\begin{tabular}{llll}
\hline Year & Country & Sector & Costs \\
\hline $1979-1989$ & EU & Sugar & ECU 3 billion/Year \\
1988 & US & Sugar & US \$ 3 billion/Year \\
1995 & Japan & Agriculture & US \$ 49.3 billion/Year \\
1994 & OECD & Agriculture & US \$ 350 billion \\
Late $1980 \mathrm{~s}$ & US & Textiles-Clothing & US \$ 27 billion \\
$1970 \mathrm{~s}$ & UK & Clothing & UK £ 500 million \\
$1970 s$ & Canada & Clothing & C \$ 780 million \\
$1981-1984$ & US & Automobiles & $41 \%$ higher price \\
1989 & France & Cars & US \$ 1.7 billion \\
\hline
\end{tabular}

Table (1): Costs of protection in some OECD countries Source: OECD (1998) 
The estimates of the costs of protectionist policies in some sectors of the economy are relatively significant and can be avoided if trade barriers are removed. These costs correspond to price increases and costs of subsidies only. Moreover, these estimates are for developed countries who, on average, have much lower tariff rates than LDCs. It is expected that these costs are much higher in LDCs and that their consumers will gain from lower prices, higher qualities and wider diversity. Thus, trade liberalization agreements under the WTO umbrella are expected to have significant effects on social welfare in the protected countries.

The survey by Feenstra (1992) of nine studies shows the sectoral costs of protection to the US economy. The estimates of these costs are presented in table (2).

(billion 1985 dollars)

Sector US DWL Quota Rents $\quad$ Foreign DWL

\begin{tabular}{lccc} 
Automobiles & $0.2-1.2$ & $2.2-7.9$ & $0-3$ \\
Dairy & 1.4 & 0.25 & 0.02 \\
Steel & $0.1-0.3$ & $0.7-2.0$ & 0.1 \\
Textile \& Apparel & $4.9-5.9$ & $4.0-6.1$ & $4-15.5$ \\
Average tariffs & $1.2-3.4$ & 0 & n.a. \\
& & & $4.3-18.8$ \\
Total & $7.9-12.3$ & $7.3-17.3$ & \\
\hline
\end{tabular}

Table (2): Costs of Protection in the US

Source: Feenstra (1992)

The first column, US DWL, presents estimates of the dead weight loss incurred by the US economy due to the presence of protectionist measures taken by the 
government to protect the four sectors displayed in the table. The total DWL to the US economy ranges between $\$ 7.9$ billion and $\$ 12.3$ billion.

The second column, Quota Rents, presents estimates of rents earned by foreign countries exporting to the US due to measures taken by the US to limit imports from these countries. These measures include import quotas and voluntary export restraints. These rents are ranging between $\$ 7.3$ billion and $\$ 17.3$ billion.

Finally, the third column presents estimates of the dead weight loss incurred by foreign countries exporting to the US. Since these numbers are positive, this means that quota rents earned by foreigners are more than offset by losses that foreigners incur due to the existence of protectionist measures by the US. These losses are between $\$ 4.3$ billion and \$18.8 billion.

Next, we present estimates of the costs of job protection in a number of OECD countries. These costs are presented in table (3).

The estimates in table (3) show how costly it is to save jobs in protected sectors producing tradable goods. It is clear that the countries surveyed is much better off, in terms of social welfare, if protection were eliminated. The gains from removing job protection range from $1.1 \%$ to $4.3 \%$ of GDP, which is clearly significant. One reason for the continuous protection of jobs in domestic industries, at high costs, is the strong lobbying that these industries have in influencing trade policies in their countries. Therefore, under the WTO agreements, governments around the world would be more constrained in responding to pressures from interest groups that push for more protection. 


\begin{tabular}{lcccc}
\hline & US & Japan & Korea & EU \\
& & & & \\
& 1994 & 1989 & 1990 & 1990 \\
Year & 21 & 47 & 49 & 20 \\
Industries Surveyed & & & & \\
Consumer Cost: & 70 & $75-110$ & $12-13$ & $97-100$ \\
Billions of \$ & 1.2 & $2.6-3.8$ & $3.8-4.3$ & $1.1-1.6$ \\
Share of GDP & 35 & 180 & 170 & 40 \\
Average Tariff & 190 & 180 & $174-405$ & 1,500 \\
Equivalent (\%) & 70 & 600 & $33-67$ & 70 \\
Jobs Saved (000) & & & & \\
Cost per Job (000\$) & & & & \\
\hline
\end{tabular}

Table (3): cost of saving jobs in some OECD countries

Source: Hufbauer (1996)

\section{(2..5.3.2) THE GAINS FROM LIBERALIZATION}

The Uruguay round has witnessed an unprecedented success evaluated by the number of agreements, especially the new areas covered by the agreement such as agriculture, textiles and clothing, services, intellectual property rights and trade related investment measures. Also the creation of the WTO as the most powerful international economic institution ever created. Moreover, the Uruguay round resulted in significant reductions in tariffs on industrial goods. All of these achievements raised the question: how much gains can be expected from the new trading system? To answer this question, dozens of studies were conducted by several international institutions (e.g. WTO, OECD, and World Bank), and by academics.

The main tool that most of the studies used is the Computable General Equilibrium (CGE) model. Most of the models assume perfect competition and constant 
returns to scale, while others consider cases of imperfect competition and economies of scale. Some are static and others dynamic in that the increase in income due to liberalization increases savings and investment, which in turn increases income in the future. Below is a discussion of some of the widely cited studies that aimed to quantify the effects of the WTO (or the Uruguay round).

According to a survey of fourteen studies about the effects of the WTO, Perroni (1998) found a wide range of model specifications that significantly affected the results. More conservative estimates were obtained from static models assuming perfect competition and constant returns to scale, while the highest estimates were obtained from dynamic models assuming imperfect competition and increasing returns to scale. For example, Francois, McDonald and Nordstrom (1994) results ranged between $\$ 51$ billion and \$291 billion or $0.31 \%-1.36 \%$ of world GDP, depending on model specification. Another study by Goldin, Kudson and Mensbrugghe (1993) gives estimates of $\$ 48$ billion for starting from a case of full employment, while the estimates increase to $\$ 235$ billion for starting from unemployment. The gains were divided between developed and developing countries as follows: \$(32-16 and 179-56) billion, respectively. Overall, Perroni concluded that the estimates of the surveyed studies are between $0.1 \%$ to $1.5 \%$ of the world GDP.

Another survey by the WTO (1999) shows that the world income will increase by $1 \%$ annually. This translates to $\$ 250$ billion to $\$ 350$ billion by 2005 . Also studies show significant growth in world trade by 5.7\% (Francois et al, 1994), 20.2\% ( Nguyen, Perroni and Wigle, 1993), and even by 59\% (Hertel, Martin, Yanagishima and Dimaranan, 1996). 
Overall, the results show that developed countries will get the biggest share of the welfare gain. This gain will accrue to consumers in developed countries who will enjoy lower prices. Results for other countries depend on their elasticities of exports and imports and on their being net exporters or net importers. Goldin et al (1993) found that African countries will lose slightly by (-0.3\%) of GDP, while other LDCs in South-East Asia and Latin America will enjoy a gain of 1-2\% of GDP.

Finally, the estimates of the effects of the WTO are less than what was expected given the number of WTO members and the wide range of trade topics covered by the agreements. These estimates suggest that the effects of the WTO agreements were underestimated empirically for a number of reasons. First, the effects of some agreements were impossible to quantify. For example, the intellectual property rights agreement, trade related investment measures agreement, and safeguards agreement. Second, even if an agreement is quantifiable, reliable data do no exist. For example, the agreement on trade in services. Finally, most of the studies ignore the agreement on services, for lack of data, but a study by Brown et al (1996) found that the gains from liberalization of trade in services are of the same magnitude as those of goods liberalization. 


\section{(2.6) THE ECONOMY OF KUWAIT}

In this section, the economy of Kuwait is described briefly using economic data. The objective is to give an overview of the economy in terms of the composition of GDP, main economic sectors, international trade patterns and a summary of economic indicators used in this study.

Kuwait is a small country located on the Northwest shore of the Persian Gulf. The population of Kuwait as of the year 2000 is 2.2 million of which $63 \%$ are foreign. The currency of Kuwait is the Kuwaiti Dinar, which equals \$3.3 US. Kuwait's main source of income comes from oil exports. For example, oil revenues accounted for $91.5 \%$ of total government's revenues during the fiscal year 1999/2000. Moreover, Kuwait's reserves of oil account for $9.3 \%$ of the world reserves. The government controls the oil industry, public utilities, telecommunications, transportation, chemical industry and some manufacturing enterprises.

\section{(2.6.1) GROSS DOMESTIC PRODUCT}

The Gross Domestic Product (GDP) of Kuwait is concentrated in two sectors: crude oil production and services. Crude oil sector accounted for $46.4 \%$ of total GDP during the period 1969-1999, while the service sector accounted for $39.7 \%$. The third largest sector is the refined oil sector, which accounted for $6.8 \%$. In an effort to reduce the reliance on the oil industry, the government of Kuwait conducted a national development plan in the 1960 s and 1970 s, but no diversification was attained until recently and oil continues to be the main source of economic activity. The two sectors that the government aims at promoting are the chemical industry and manufacturing, which account for $0.7 \%$ 
and $2.8 \%$ of GDP, respectively. Table (4) below shows the eight components of GDP and their share in total GDP during the 1969-1999 period.

\begin{tabular}{lcccccccc}
\hline & GDP & Agric. & Chemi. & C. Oil & Const. & Manuf. & Serv. & R. Oil \\
\hline Average & 5051.6 & 21.4 & 37.8 & 2343.3 & 160.9 & 141.0 & 2004.5 & 342.7 \\
$\begin{array}{l}\text { \% of } \\
\text { GDP }\end{array}$ & 100 & 0.4 & 0.7 & 46.4 & 3.2 & 2.8 & 39.7 & 6.8 \\
\hline
\end{tabular}

Where: Agric. is Agriculture and Fishery, Chemi. is chemical, C. Oil is crude oil, Const. is Construction, Mnuf. is manufacturing, Serv. is services, and R. Oil is refined oil.

Table (4): Components of GDP

\section{(2.6.2) INTERNATIONAL TRADE}

Kuwait has an open economy in which exports and imports in 1999 accounted for $47 \%$ and $37 \%$ of GDP, respectively. In 1999, oil exports accounted for $90 \%$ of total exports, while chemicals accounted for $6 \%$, machinery for $1.3 \%$ and manufactured exports for $1 \%$. Because chemical exports are the second largest category of exports after oil, they will be specified in this study as the exportable good (X). Chemical exports are composed of the following: fertilizers, plastic, inorganic chemicals, essential oils and cleansing materials.

The composition of imports during the period 1969-1999 was as follows: capital goods $40 \%$, manufactured goods $36.5 \%$, food $14.7 \%$ and crude materials $8 \%$. Under the current customs' regime, food, capital goods and crude materials enter Kuwait duty free. Only manufactured goods (other than capital goods) are taxed at a $4 \%$ tariff rate, therefore they will be specified in this study as the importable good (Y). Manufactured goods include the following products: leather, wood, paper, textiles and metals. 
Kuwait trades with a large number of countries. Trade partners differ according to the direction of trade (i.e. exports vs. imports) and good categories. Excluding oil, Kuwait's non-oil exports go mainly to Asian markets, which account for $81.6 \%$. About one third of Kuwait's exports go to the countries of the Gulf Cooperation Council (GCC), while $13.3 \%$ go to India, $11.2 \%$ Arab countries (excluding GCC countries), $6.2 \%$ to china, $6.2 \%$ the EU and $4.7 \%$ to the US. Table (5) provides a summary of destinations of Kuwait's exports as an average for the period 1995-1999.

\begin{tabular}{lc}
\hline Country & \% of Total Exports \\
\hline & \\
GCC Countries & 33.0 \\
India & 13.3 \\
Arab Countries & 11.2 \\
China & 6.20 \\
Other Asians & 24.0 \\
E. U. & 6.20 \\
USA & 4.70 \\
\hline
\end{tabular}

Table (5): Destinations of Non-Oil Exports

Kuwait's imports are more diversified than exports and come from three important groups of countries. Asian countries account for the largest portion with a share of $42 \%$. Main Asian exporters are Japan 12.3\%, India 3.4 and China 2.7\%. The European Union's share is $34.3 \%$, while the US's share is $14.8 \%$. Table (6) provides a summary of the main sources of Kuwait's imports during the period 1995-1999. 


\begin{tabular}{lc}
\hline Country & \% of Total Imports \\
\hline & \\
E. U. & 34.3 \\
USA & 14.8 \\
Japan & 12.3 \\
Other Asians & 12.0 \\
GCC Countries & 10.0 \\
India & 3.4 \\
Arab Countries & 2.8 \\
China & 2.7 \\
& \\
\hline
\end{tabular}

Table (6): Sources of Imports

\section{(2.6.3) SUMMARY OF THE DATA}

In this subsection, a summary of the data of the exportable good (X) and the importable good $(\mathrm{Y})$ is provided to assist the reader in understanding the results that are to be obtained from the empirical analysis in chapters four and five. The summary covers imports, exports, demand for capital and labor and production. All statistics are specified as percentages of non-oil GDP and the totals of the same category. Table (7) provides this summary for the period 1969-1999.

\section{Category $\quad$ Percentage Rate (\%)}

Imports of (Y) / Total Imports

Imports of (Y) / Non-Oil GDP

Exports of (X)/ Total Exports

Exports of (X) / Non-Oil Exports

Exports of (X) / Non-Oil GDP

Capital in Sector (X) / Total Capital

Capital in Sector (Y) / Total Capital

Labor in Sector (Y) / Labor Force

Labor in Sector (X) / Labor Force

Production of $(\mathrm{X}) /$ Non-Oil GDP

Production of (Y) / Non-Oil GDP
36.5

19.0

1.60

18.6

1.50

3.10

2.30

5.00

0.40

3.00

11.6

Table (7): Summary of Data 


\section{CHAPTER (3)}

\section{THE MODEL}

\section{INTRODUCTION}

This chapter presents the model that is used in chapters four and five in estimation and simulation, respectively. The chapter consists of four main sections and a number of subsections. Section (3.1) presents the model's set up and derive demand and supply functions for both output and production factors. This section, for simplicity, does not introduce trade policy. Trade policy is introduced in section (3.2), while section (3.3) derives measures to quantify the economic effects of tariffs' agreement. Finally, section (3.4) discusses the economic effects of other WTO agreements that have a direct effect on the economy of Kuwait. 


\section{(3.1) THE MODEL}

This is a two-sector general equilibrium trade model for a small open economy. It is based on the Heckscher-Ohlin (H-O) model. The economy produces two goods ( $\mathrm{X}$ and Y) using two factors of production, capital (K) and labor (L). The home country has an excess supply of good $(\mathrm{X})$ that it exports to the foreign country. Thus, good (X) is the exportable good. The home country has an excess demand for good (Y) that is met by imports from the foreign country. Thus, good (Y) is the importable good. Therefore, excess supply and excess demand of each good creates the need for the home country to engage in trade with the foreign country. The home country is modeled as a small country while the foreign country is a large country, e.g. the rest of the world. This makes the home country a price taker and the foreign country a price setter. The emphasis of the model is on the home country.

An important assumption in the $\mathrm{H}-\mathrm{O}$ model is that goods produced in different countries are perfect substitutes (i.e. homogenous goods), which means that they are sold at one price. This assumption implies that a good can be either imported or exported, but not exported and imported at the same time (Hatta and Fukushima, 1979). In other words, there is no two way trade. This is in contrast with the Armington Assumption that goods produced in different countries are imperfect substitutes (Armington, 1969). This violates the small country assumption for the following reason: if domestic and imported goods can be differentiated, this means that they must be sold at different prices, which implies that the small country has an influence on its terms of trade (i.e. relative prices). This contradicts the assumption that the small country is a price taker. 
The behavior of economic agents in the home country is modeled by the behavior of three representative agents: a household, a firm and a government. The preferences of the household are characterized by a Cobb- Douglas utility function. The objective of the household is to maximize its utility function subject to a budget constraint. The firm's technology is characterized by a constant returns to scale CobbDouglas production function. The firm's objective is to minimize the costs of production (= maximize profit) for a given quantity of output. Finally, the government's objective is to keep its budget balanced by equating its total revenues coming from oil exports and import tariffs to its transfer payments to households and costs of producing public services. The latter include hiring domestic labor in the service sector and buying goods necessary for the production of services from domestic producers. One more detail, in addition to trade in goods ( $\mathrm{X}$ and $\mathrm{Y}$ ), the home country exports oil to the foreign country and imports capital goods from the latter.

The model that is derived in the first four subsections consists of (12) equations describing the behavior of the three representative agents in the home country. There are eight behavioral equations (two for the household and six for the firm) and four identities. 


\section{(3.1.1) THE FIRM}

The firm operates in perfectly competitive markets for goods and factors of production. It produces two homogenous goods ( $\mathrm{X}$ and $\mathrm{Y}$ ) using two factors; capital and labor. Both factors can be perfectly mobilized between the production of the two goods. The firm's objective is to maximize profits which implies minimizing costs (Varian, 1992). The production technology is characterized by a constant returns to scale CobbDouglas function with two factors; capital and labor:

$$
\left.\mathrm{F}_{\mathrm{Y}}\left(\mathrm{K}_{\mathrm{Y}}, \mathrm{N}_{\mathrm{Y}}\right)=\mathrm{L}^{\beta}{ }_{\mathrm{Y}} \mathrm{K}^{1-\beta} \mathrm{F}_{\mathrm{Y}} \quad \text { and } \quad \mathrm{K}_{\mathrm{X}}, \mathrm{N}_{\mathrm{X}}\right)=\mathrm{L}_{\mathrm{X}}^{\delta} \mathrm{K}^{1-\delta} \mathrm{X}
$$

The total cost function (TC) consists of the costs of hiring labor and the costs of acquiring capital:

$\mathrm{TC}_{\mathrm{i}}\left(\mathrm{w}, \mathrm{r}, \mathrm{Q}_{\mathrm{i}}\right)=\mathrm{w} \mathrm{L}_{\mathrm{i}}+\mathrm{r} \mathrm{K}_{\mathrm{i}}$ where $\mathrm{i}=\mathrm{X}, \mathrm{Y}$

Labor costs equal the number of workers hired multiplied by the real wage rate. Capital costs equal the stock of capital used multiplied by the rental price of capital, which equals the net real interest rate. This means that factors of production are paid their value marginal product. This is due to the assumption of perfect competition (i.e. zero economic profits). 
The solution to the problem involves expressing all the endogenous variables as functions of output prices and factor endowments $\left(\mathrm{P}_{\mathrm{i}}, \mathrm{L}, \mathrm{K}\right)$. The following steps is followed in solving the problem. First I will solve the problem for good (Y) and then for $\operatorname{good}(\mathrm{X})$.

1. State the minimization problem

$\operatorname{Min} . \mathrm{TC}_{\mathrm{Y}}\left(\mathrm{w}, \mathrm{r}, \mathrm{Q}_{\mathrm{Y}}\right)=\mathrm{w} \mathrm{L}_{\mathrm{Y}}+\mathrm{r} \mathrm{K}_{\mathrm{Y}}$

Subject to $Q_{Y}=L^{\beta} K^{1-\beta}$

The lagrangian of the problem is:

$\left.f_{Y}=w_{Y}+r K_{Y}+\lambda\left(Q_{Y}-L^{\beta}{ }_{Y} K^{1-\beta}\right)\right)$

2. Finding the first order conditions with respect to labor and capital.

$\partial \mathfrak{f}_{\mathrm{Y}} / \partial \mathrm{L}_{\mathrm{Y}}: \mathrm{W}-\lambda \beta \mathrm{L}^{\beta-1} \mathrm{Y}^{1-\beta}{ }_{\mathrm{Y}}=0$

$\partial \mathfrak{f}_{\mathrm{Y}} / \partial \mathrm{K}_{\mathrm{Y}}: \mathrm{r}-\lambda(\beta-1) \mathrm{L}^{\beta}{ }_{\mathrm{Y}} \mathrm{K}^{-\beta}{ }_{\mathrm{Y}}=0$

3. Finding the cost function

After solving the first order conditions for $\mathrm{K}_{\mathrm{Y}}$ and $\mathrm{L}_{\mathrm{Y}}$, we plug them in the cost function:

$$
\begin{aligned}
\operatorname{TC}_{Y}\left(w, r, Q_{Y}\right) & =Q_{Y}\left[w^{\beta}\left(r^{-1}(1-\beta) / \beta\right)^{\beta-1}+r^{1-\beta}(w(1-\beta) / \beta)^{\beta}\right] \\
= & Q_{Y} A w^{\beta} r^{1-\beta}
\end{aligned}
$$

Where $(A)=((1-\beta) / \beta)^{\beta-1}+((1-\beta) / \beta)^{\beta}$ 


\section{Finding the marginal cost}

First find the first order condition of the cost function with respect to output. Then, equate it to the price of output $\left(\mathrm{P}_{\mathrm{Y}}\right)$ (i.e. because of the assumption of perfect competition).

$\mathrm{P}_{\mathrm{Y}}=\mathrm{MC}_{\mathrm{Y}}=\partial \mathrm{TC}_{\mathrm{Y}} / \partial \mathrm{Q}_{\mathrm{Y}}=\mathrm{Aw}^{\beta} \mathrm{r}^{1-\beta}$

After finding the price equation for good (Y), follow the steps 1-4 to find the price equation for good $(\mathrm{X})$, which has the following form:

$\mathrm{P}_{\mathrm{X}}=\mathrm{MC}_{\mathrm{X}}=\partial \mathrm{TC}_{\mathrm{X}} / \partial \mathrm{QX}_{\mathrm{X}}=\mathrm{Z} \mathrm{w}^{\delta} \mathrm{r}^{1-\delta}$

Where $(Z)=((1-\delta) / \delta)^{\delta-1}+((1-\delta) / \delta)^{\delta}$

5. Solving the price equations for the wage rate and the interest rate.

The two price equations are functions of two unknowns ( $w$ and $r$ ), so it is easy to solve for $(\mathrm{w}$ and $\mathrm{r})$ simultaneously in terms of prices $\left(\mathrm{P}_{\mathrm{X}}\right.$ and $\left.\mathrm{P}_{\mathrm{Y}}\right)$ :

$$
\begin{aligned}
& r=\left(\mathrm{P}_{\mathrm{Y}} \mathrm{A}^{-1}\right)^{\delta /(\delta-\beta)}\left(\mathrm{P}_{\mathrm{X}} \mathrm{Z}^{-1}\right)^{-\beta /(\delta-\beta)} \\
& \mathrm{w}=\left(\mathrm{P}_{\mathrm{X}} \mathrm{Z}^{-1}\right)^{1-\beta /(\delta-\beta)}\left(\mathrm{P}_{\mathrm{Y}} \mathrm{A}^{-1}\right)^{\delta-1 /(\delta-\beta)}
\end{aligned}
$$

\section{Specifying the revenue function}

Specify the "firm's" revenue function and then find the first order conditions with respect to prices. This gives output (due to Hotelling's Lemma) as a function of output prices and factor endowments $\left(\mathrm{P}_{\mathrm{X}}, \mathrm{P}_{\mathrm{Y}}, \mathrm{L}, \mathrm{K}\right)$. Because of the zero profit condition 
implied by the perfect competition assumption, revenues (R) equal costs:

$$
\begin{aligned}
& \mathrm{R}=\mathrm{w}\left(\mathrm{L}_{\mathrm{Y}}+\mathrm{L}_{\mathrm{X}}\right)+\mathrm{r}\left(\mathrm{K}_{\mathrm{Y}}+\mathrm{K}_{\mathrm{X}}\right) \\
& \mathrm{R}=\left(\mathrm{P}_{\mathrm{X}} \mathrm{Z}^{-1}\right)^{1-\beta /(\delta-\beta)}\left(\mathrm{P}_{\mathrm{Y}} \mathrm{A}^{-1}\right)^{\delta-1 /(\delta-\beta)}\left(\mathrm{L}_{\mathrm{Y}}+\mathrm{L}_{\mathrm{X}}\right)+\left(\mathrm{P}_{\mathrm{Y}} \mathrm{A}^{-1}\right)^{\delta /(\delta-\beta)}\left(\mathrm{P}_{\mathrm{X}} \mathrm{Z}^{-1}\right)^{-\beta /(\delta-\beta)}\left(\mathrm{K}_{\mathrm{Y}}+\mathrm{K}_{\mathrm{X}}\right) \\
& \mathrm{Q}_{\mathrm{i}}=\left(\partial \mathrm{w} / \partial \mathrm{P}_{\mathrm{i}}\right)\left(\mathrm{L}_{\mathrm{Y}}+\mathrm{L}_{\mathrm{X}}\right)+\left(\partial \mathrm{r} / \partial \mathrm{P}_{\mathrm{i}}\right)\left(\mathrm{L}_{\mathrm{Y}}+\mathrm{L}_{\mathrm{X}}\right) \\
& \mathrm{Q}_{\mathrm{Y}}=\partial \mathrm{R} / \partial \mathrm{P}_{\mathrm{Y}}=((\delta-1) / \delta-\beta)\left(\mathrm{P}_{\mathrm{X}} \mathrm{Z}^{-1}\right)^{1-\beta / \delta-\beta)}\left(\mathrm{P}_{\mathrm{Y}} \mathrm{A}^{-1}\right)^{\beta-1 /(\delta-\beta)} \mathrm{A}^{-1}\left(\mathrm{~L}_{\mathrm{Y}}+\mathrm{L}_{\mathrm{X}}\right) \\
& +(\delta /(\delta-\beta))\left(\mathrm{P}_{\mathrm{Y}} \mathrm{A}^{-1}\right)^{\beta /(\delta-\beta)} \mathrm{A}^{-1}\left(\mathrm{P}_{\mathrm{X}} \mathrm{Z}^{-1}\right)^{-\beta /(\delta-\beta)}\left(\mathrm{K}_{\mathrm{Y}}+\mathrm{K}_{\mathrm{X}}\right) \\
& \mathrm{Q}_{\mathrm{X}}=\partial \mathrm{R} / \partial \mathrm{P}_{\mathrm{X}}=((1-\beta) / \delta-\beta)\left(\mathrm{P}_{\mathrm{X}} \mathrm{Z}^{-1}\right)^{1-\delta /(\delta-\beta)} \mathrm{Z}^{-1}\left(\mathrm{P}_{\mathrm{Y}} \mathrm{A}^{-1}\right)^{\delta-1 /(\delta-\beta)}\left(\mathrm{L}_{\mathrm{Y}}+\mathrm{L}_{\mathrm{X}}\right) \\
& -(\beta /(\delta-\beta))\left(\mathrm{P}_{\mathrm{Y}} \mathrm{A}^{-1}\right)^{\delta /(\delta-\beta)}\left(\mathrm{P}_{\mathrm{X}} \mathrm{Z}^{-1}\right)^{-\delta /(\delta-\beta)} \mathrm{Z}^{-1}\left(\mathrm{~K}_{\mathrm{Y}}+\mathrm{K}_{\mathrm{X}}\right)
\end{aligned}
$$

The above equations can be used to solve for the demand for labor and capital functions. This is done by substituting the above equations, the wage rate (w) and the interest rate (r) equations into the total cost function which gives demand equations in terms of output prices and factor endowments:

$$
\begin{aligned}
& \mathrm{L}_{Y}=\partial \mathrm{TC}_{\mathrm{Y}} / \partial \mathrm{w}=\mathrm{Q}_{\mathrm{Y}}\left(\mathrm{P}_{\mathrm{X}}, \mathrm{P}_{\mathrm{Y}}, \mathrm{L}, \mathrm{K}\right)\left[\beta \mathrm{w}\left(\mathrm{P}_{\mathrm{X}}, \mathrm{P}_{\mathrm{Y}}\right) \mathrm{r}\left(\mathrm{P}_{\mathrm{X}}, \mathrm{P}_{\mathrm{Y}}\right) \mathrm{A}\right] \\
& \mathrm{K}_{\mathrm{Y}}=\partial \mathrm{TC}_{\mathrm{Y}} / \partial \mathrm{r}=\mathrm{Q}_{\mathrm{Y}}\left(\mathrm{P}_{\mathrm{X}}, \mathrm{P}_{\mathrm{Y}}, \mathrm{L}, \mathrm{K}\right)\left[(1-\beta) \mathrm{w}\left(\mathrm{P}_{\mathrm{X}}, \mathrm{P}_{\mathrm{Y}}\right) \mathrm{r}\left(\mathrm{P}_{\mathrm{X}}, \mathrm{P}_{\mathrm{Y}}\right) \mathrm{A}\right] \\
& \mathrm{L}_{\mathrm{X}}=\partial \mathrm{TC}_{\mathrm{X}} / \partial \mathrm{w}=\mathrm{Q}_{\mathrm{X}}\left(\mathrm{P}_{\mathrm{X}}, \mathrm{P}_{\mathrm{Y}}, \mathrm{L}, \mathrm{K}\right)\left[\delta \mathrm{w}\left(\mathrm{P}_{\mathrm{X}}, \mathrm{P}_{\mathrm{Y}}\right) \mathrm{r}\left(\mathrm{P}_{\mathrm{X}}, \mathrm{P}_{\mathrm{Y}}\right) \mathrm{Z}\right] \\
& \mathrm{K}_{\mathrm{X}}=\partial \mathrm{TC}_{\mathrm{X}} / \partial \mathrm{r}=\mathrm{Q}_{\mathrm{X}}\left(\mathrm{P}_{\mathrm{X}}, \mathrm{P}_{\mathrm{Y}}, \mathrm{L}, \mathrm{K}\right)\left[(1-\delta) \mathrm{w}\left(\mathrm{P}_{\mathrm{X}}, \mathrm{P}_{\mathrm{Y}}\right) \mathrm{r}\left(\mathrm{P}_{\mathrm{X}}, \mathrm{P}_{\mathrm{Y}}\right) \mathrm{Z}\right]
\end{aligned}
$$




\section{Comparative Statics}

The following analysis utilizes the properties of the revenue function and is based on Dixit and Norman (1980).

The revenue function is defined as: $\mathrm{R}\left(\mathrm{P}_{\mathrm{X}}, \mathrm{P}_{\mathrm{Y}}, \mathrm{K}, \mathrm{L}\right)$.

The derivatives of the revenue function with respect to prices give the supply functions, $\mathrm{R}_{1}=\mathrm{Q}_{\mathrm{X}}\left(\mathrm{P}_{\mathrm{X}}, \mathrm{P}_{\mathrm{Y}}, \mathrm{K}, \mathrm{L}\right)$

$\mathrm{R}_{2}=\mathrm{Q}_{\mathrm{Y}}\left(\mathrm{P}_{\mathrm{X}}, \mathrm{P}_{\mathrm{Y}}, \mathrm{K}, \mathrm{L}\right)$

Due to the convexity of $\mathrm{R}$ in $\mathrm{P}$,

$\mathrm{R}_{11} \geq 0$

$\mathrm{R}_{22} \geq 0$

Moreover, because $\mathrm{R}_{\mathrm{i}}$ is homogeneous of degree zero in $\mathrm{P}$, Euler's Theorem can be used to sign $\mathrm{R}_{\mathrm{ij}}$,

$\mathrm{R}_{\mathrm{i}}=\mathrm{R}_{\mathrm{i}}\left(\mathrm{P}_{\mathrm{X}}, \mathrm{P}_{\mathrm{Y}}, \overline{\mathrm{K}}, \overline{\mathrm{L}}\right)$

$0=\mathrm{R}_{11} \mathrm{P}_{\mathrm{X}}+\mathrm{R}_{12} \mathrm{P}_{\mathrm{Y}}$

$0=\mathrm{R}_{21} \mathrm{P}_{\mathrm{X}}+\mathrm{R}_{22} \mathrm{P}_{\mathrm{Y}}$

The first term on the right hand side in (3) is non-negative due to the convexity of the revenue function in prices. The second term has to be non-positive in order for the identity to hold. Thus, $\mathrm{R}_{12}$ is non-positive. For $\mathrm{R}_{2}$, the second term in (4) has to be nonnegative due to the convexity of the revenue function, thus the first term has to be nonpositive for the identity to hold, which means that $\mathrm{R}_{21}$ is non-negative.

The signs of the derivatives of $R_{1}$ and $R_{2}$ with respect to (K and $L$ ) depend on the intensity of factors used in the production of each good. According to Rybcznski's Theorem, an increase in the endowment of a factor of production increases the output of 
the good that uses this factor intensively and reduces production of the other good. In the case of good (Y), which is labor intensive,

$\mathrm{R}_{23}<0$

and

$\mathrm{R}_{24}>0$

while in the case of good (X), which is capital intensive,

$\mathrm{R}_{13}>0$

and

$\mathrm{R}_{14}<0$

Next, the derivatives of the revenue function with respect to factors of production can be used to obtain the returns to these factors.

$\mathrm{R}_{3}=\mathrm{r}\left(\mathrm{P}_{\mathrm{X}}, \mathrm{P}_{\mathrm{Y}}, \mathrm{K}, \mathrm{L}\right)$

$\mathrm{R}_{4}=\mathrm{w}\left(\mathrm{P}_{\mathrm{X}}, \mathrm{P}_{\mathrm{Y}}, \mathrm{K}, \mathrm{L}\right)$

Utilizing the Samuelson-Stolper Theorem, which states that an increase in the price of a good increases the return to the factor of production that is used intensively in its production and reduces the return to the other input, the effects of changes in output prices on the returns to factors of production can be obtained. For example, because good $(\mathrm{X})$ is capital intensive, then an increase in its price increases the return to capital (r) and reduces the return to labor $(\mathrm{w})$. Th opposite is true for good $(\mathrm{Y})$, which is labor intensive.

$\mathrm{R}_{31} \geq 0$

$\mathrm{R}_{42} \geq 0$

$\mathrm{R}_{32} \leq 0$

$\mathrm{R}_{41} \leq 0$ 
Under the assumption of constant returns to scale, the cost function is

homogeneous of degree one,

$\mathrm{C}(\mathrm{w}, \mathrm{r}, \mathrm{y})=\mathrm{y}(\mathrm{w}, \mathrm{r}, 1)$

Average cost $(\mathrm{AC})=\mathrm{C}(\mathrm{w}, \mathrm{r}, 1)$

Moreover, under perfect competition, price equals average cost and marginal cost.

Thus,

$\mathrm{P}_{\mathrm{X}}=\mathrm{C}_{\mathrm{X}}(\mathrm{w}, \mathrm{r}, 1)$

$\mathrm{P}_{\mathrm{Y}}=\mathrm{C}_{\mathrm{Y}}(\mathrm{w}, \mathrm{r}, 1)$

Where $C_{i}$ is the marginal cost with respect $Q_{i}$. But since (w and $r$ ) were shown (in section 3.1.1) to be functions of $\left(\mathrm{P}_{\mathrm{X}}\right.$ and $\left.\mathrm{P}_{\mathrm{Y}}\right)$, the above equations can be rewritten as follows:

$\mathrm{w}=\mathrm{w}\left(\mathrm{P}_{\mathrm{X}}, \mathrm{P}_{\mathrm{Y}}\right)$

$\mathrm{r}=\mathrm{r}\left(\mathrm{P}_{\mathrm{X}}, \mathrm{P}_{\mathrm{Y}}\right)$

$\partial w / \partial L=0$

$\partial w / \partial K=0$

$\partial \mathrm{r} / \partial \mathrm{L}=0$

$\partial \mathrm{r} / \partial \mathrm{K}=0$

Because ( $\mathrm{w}$ and $\mathrm{r}$ ) are homogeneous of degree zero in ( $\mathrm{L}$ and $\mathrm{K})$. This result is valid only in the H-O model, not in general. 


\section{$\underline{\text { Linearization }}$}

The supply functions $\left(\mathrm{Q}_{\mathrm{i}}\right)$ are reduced-form equations that can be rewritten using the implicit function theorem as follows:

$\mathrm{Q}_{\mathrm{X}}=\mathrm{F}\left(\mathrm{P}_{\mathrm{Y}}, \mathrm{P}_{\mathrm{X}}, \mathrm{L}, \mathrm{K}\right)$

$\mathrm{Q}_{\mathrm{Y}}=\mathrm{F}\left(\mathrm{P}_{\mathrm{Y}}, \mathrm{P}_{\mathrm{X}}, \mathrm{L}, \mathrm{K}\right)$

Using the above specifications, the two equations can be estimated as follows:

Note: a number in parenthesis next to an expected sign corresponds to the number of an equation in the comparative static subsection from which the sign was obtained.

$\mathbf{Q X}_{\mathbf{X}}=\phi 0+\phi 1 \mathbf{P}_{\mathbf{X}}+\phi 2 \mathbf{P}_{\mathbf{Y}}+\phi 3 \mathbf{K}+\phi 4 \mathbf{L}+\mathbf{e}$

Expected Signs: $\phi 1 \geq 0(1), \phi 2 \leq 0(3), \phi 3>0$ (7) and $\phi 4<0$ (8).

$\mathbf{Q}_{\mathbf{Y}}=\varphi \mathbf{0}+\varphi 1 \mathbf{P}_{\mathbf{X}}+\varphi 2 \mathbf{P}_{\mathbf{Y}}+\varphi \mathbf{3}+\varphi 4 \mathbf{L}+\mathbf{e}$

Expected Signs: $\varphi 1 \leq 0(4), \varphi 2 \geq 0(2), \varphi 3<0$ (5) and $\varphi 4>0$ (6).

Where (e ) is an error term.

Similarly, the demand for factors of production $\left(\mathrm{L}_{\mathrm{i}}\right.$ and $\left.\mathrm{K}_{\mathrm{i}}\right)$ can be rewritten using the implicit function theorem as follows:

$$
\begin{aligned}
& \mathrm{L}_{\mathrm{Y}}=\mathrm{G}\left(\mathrm{P}_{\mathrm{Y}}, \mathrm{P}_{\mathrm{X}}, \mathrm{L}, \mathrm{K}\right) \\
& \mathrm{K}_{\mathrm{Y}}=\mathrm{G}\left(\mathrm{P}_{\mathrm{Y}}, \mathrm{P}_{\mathrm{X}}, \mathrm{K}, \mathrm{L}\right) \\
& \mathrm{L}_{\mathrm{X}}=\mathrm{G}\left(\mathrm{P}_{\mathrm{Y}}, \mathrm{P}_{\mathrm{X}}, \mathrm{K}, \mathrm{L}\right) \\
& \mathrm{K}_{\mathrm{X}}=\mathrm{G}\left(\mathrm{P}_{\mathrm{Y}}, \mathrm{P}_{\mathrm{X}}, \mathrm{K}, \mathrm{L}\right)
\end{aligned}
$$

Using the above specifications, the four equations can be estimated as follows:

$$
\mathbf{L}_{\mathbf{Y}}=\xi_{\mathbf{0}}+\xi_{1} \mathbf{P}_{\mathbf{X}}+\xi_{2} \mathbf{P}_{\mathbf{Y}}+\xi_{3} \mathbf{K}+\xi_{4} \mathbf{L}+\mathbf{e}
$$

Expected Signs: $\xi 1 \leq 0$ (12), $\xi_{2} \geq 0$ (10), $\xi 3 \leq 0$ (R. Them.) and $\xi 4 \geq 0$ (R. Them).

Note: R. Them. is Rybcznski's Theorem. 
$\mathbf{K}_{\mathbf{Y}}=\mu \mathbf{0}+\mu 1 \mathbf{P}_{\mathbf{X}}+\mu 2 \mathbf{P}_{\mathbf{Y}}+\mu 3 \mathbf{K}+\mu 4 \mathbf{L}+\mathrm{e}$

Expected Signs: $\mu 1 \leq 0$ (9), $\mu 2 \geq 0$ (11), $\mu 3 \leq 0$ (R. Them.) and $\mu 4 \geq 0$ (R Them).

$\mathbf{L}_{\mathbf{X}}=\Omega 0+\Omega 1 \mathbf{P}_{\mathbf{X}}+\Omega 2 \mathbf{P}_{\mathbf{Y}}+\Omega 3 \mathbf{K}+\Omega 4 \mathbf{L}+\mathbf{e}$

Expected Signs: $\Omega 1 \geq 0$ (12), $\Omega 2 \leq 0$ (10), $\Omega 3 \geq 0$ (R. Them.) and $\Omega 4 \leq 0$ (R. Them).

$\mathbf{K}_{\mathbf{X}}=\theta 0+\theta 1 \mathbf{P}_{\mathbf{X}}+\theta 2 \mathbf{P}_{\mathbf{Y}}+\theta \mathbf{3} \mathbf{K}+\theta \mathbf{L} \mathbf{L}+\mathbf{e}$

Expected Signs: $\theta 1 \geq 0$ (9), $\theta 2 \leq 0$ (11), $\theta 3 \geq 0$ (R. Them.) and $\theta 4 \leq 0$ (R. Them.).

Where (e) is an error term.

Note: $\mathrm{Q}_{\mathrm{i}}$ and $\mathrm{K}_{\mathrm{i}}$ are in real terms since they were derived from optimization behavior. 


\section{(3.1.2) THE HOUSEHOLD}

In the model, a representative household is maximizing a utility function that depends on consumption only. Consumption includes expenditures on two consumption goods and one free public service. The utility function has a quasi-linear form:

$$
\mathrm{U}\left(\mathrm{C}_{\mathrm{Y}}, \mathrm{C}_{\mathrm{X}}, \mathrm{C}_{\mathrm{S}}\right)=\mathrm{C}_{\mathrm{Y}}^{\alpha 1} \mathrm{C}_{\mathrm{X}}^{\alpha 2}+\mathrm{C}_{\mathrm{S}}
$$

The first term in the utility function is the familiar Cobb-Douglas constant returns to scale function $(\alpha 1+\alpha 2=1)$. The second term needs some clarification.

Individuals get utility from consuming both goods and services in their real life, however, the latter is usually ignored in Economics literature. In the model it is important to include this term because public services in Kuwait are produced by the government using mainly Kuwaiti labor who are paid generously, on one hand. On the other hand, public services are provided at very low prices even below their cost of production. For example, the cost of producing one Kilo Watt of electricity is KD 0.0186 , but is sold for KD 0.002. Also, the cost of producing one Imperial Gallon of fresh water is KD2.21, but it is sold for KD 0.8. Moreover, the government buys most of the inputs used in the production of these services from domestic producers who pay even lower prices for services. For example, factories in the "Shuaiba" industrial Zone pay KD 0.001 and KD 0.25 for electricity and water, respectively. This is an indirect way of subsidizing domestic producers. Therefore, it's clear that services produced by the government have an important role in subsidizing both consumers and producers. 
In the model the government uses whatever revenues it gets from oil exports to provide subsidized services ( $\mathrm{S}$ ), buy goods ( $\mathrm{X}$ and $\mathrm{Y})$, and make transfer payments $(\mathrm{T})$ to the household:

$$
\overline{\mathrm{G}}=\mathrm{P}_{\mathrm{S}} \mathrm{N} \mathrm{C_{S }}+\mathrm{P}_{\mathrm{X}} \mathrm{G}_{\mathrm{X}}+\mathrm{P}_{\mathrm{Y}} \mathrm{G}_{\mathrm{Y}}+\mathrm{T}
$$

Where:

$$
\begin{aligned}
& \overline{\mathrm{G}} \text { : government expenditure. } \\
& \mathrm{P}_{\mathrm{S}} \text { : price of public services } \\
& \mathrm{N} \text { : population } \\
& \mathrm{P}_{\mathrm{X}} \text { : price of good } \mathrm{X} \\
& \mathrm{G}_{\mathrm{X}} \text { : government consumption of good } \mathrm{X} \\
& \mathrm{P}_{\mathrm{Y}} \text { : price of good } \mathrm{Y} \\
& \text { GY: government consumption of good } \mathrm{Y}
\end{aligned}
$$

To obtain an expression for the household's consumption of the public service, we rearrange the above equation

$$
\mathrm{P}_{\mathrm{S}} \mathrm{NC}_{\mathrm{S}}=\overline{\mathrm{G}}-\left(\mathrm{P}_{\mathrm{X}} \mathrm{G}_{\mathrm{X}}+\mathrm{P}_{\mathrm{Y}} \mathrm{G}_{\mathrm{Y}}+\mathrm{T}\right)
$$

This shows that the government's expenditure on public services is a residual. That is, the difference between total expenditures and expenditures on goods ( $\mathrm{X}$ and $\mathrm{Y}$ ) and transfer payments. Each household's share of total services is:

$$
\mathrm{C}_{\mathrm{S}}=\left(\overline{\mathrm{G}}-\left(\mathrm{P}_{\mathrm{X}} \mathrm{G}_{\mathrm{X}}+\mathrm{P}_{\mathrm{Y}} \mathrm{G}_{\mathrm{Y}}+\mathrm{T}\right)\right) / \mathrm{NP}_{\mathrm{S}}
$$

Moreover, in the model $\left(\mathrm{C}_{\mathrm{S}}\right)$ is not chosen by the household but, it is exogenously given to it by the government. It also doesn't show up in the household's budget constraint because of its low price, which makes its cost negligible to the household.

The assumption that the household gets utility only from its consumption of goods and services implies that the household does not value leisure and is willing to devote all of its time to work. In other words, it has a perfectly elastic labor supply curve. 
Utility maximization is subject to a budget constraint stating that consumption of goods ( $\mathrm{X}$ and $\mathrm{Y}$ ) must be equal to the household's income from work, transfers, and interest payments on its initial endowment of capital. It is common in studies dealing with oil exporting countries in general and Kuwait in particular to subtract oil revenues from total income (i.e. GDP). That is because the high fluctuations in these revenues do not reflect actual changes in the economy and they accrue directly to the government, which monopolizes the oil sector (Morgan, 1979, Crockett and Evans, 1980, Sangarabalan, 1984, Moosa, 1986, Fadil, 1989, and Algahtani, 1992).

Therefore, the household's budget constraint is specified as follows:

$\mathrm{M}=\mathrm{P}_{\mathrm{Y}} \mathrm{C}_{\mathrm{Y}}+\mathrm{P}_{\mathrm{X}} \mathrm{C}_{\mathrm{X}}$

Where $\mathrm{M}$ is the household's income ( $\mathrm{w} \mathrm{L}+\mathrm{r} \mathrm{K}+\mathrm{T}$ )

The solution to the household's problem is given below.

$$
\begin{aligned}
& £=C^{\alpha 1}{ }_{Y} C^{\alpha 2}{ }_{X}+C_{S}+\lambda\left(M-P_{Y} C_{Y}-P_{X} C_{X}\right) \\
& \text { F.O.C.s } \\
& \partial f / \partial C_{Y}: \alpha 1 C^{\alpha 1-1}{ }_{Y} C^{\alpha 2}{ }_{X}-\lambda P_{Y}=0 \\
& \partial f / \partial C_{X}: \alpha 2 C^{\alpha 1}{ }_{Y} C^{\alpha 2-1}{ }_{X}-\lambda P_{X}=0 \\
& \partial f / \partial \lambda: \quad \quad M-P_{Y} C_{Y}-P_{X} C_{X}=0
\end{aligned}
$$

Divide (1) by (2) and solve for $\mathrm{C}_{\mathrm{X}}=\left(\mathrm{P}_{\mathrm{Y}} / \mathrm{P}_{\mathrm{X}}\right)(\alpha 2 / \alpha 1) \mathrm{C}_{\mathrm{Y}}$

Plug $C_{X}$ into (3) and solve for the optimal values of $C_{Y}$ and $C_{X}$ plus $C_{S}$

$$
\begin{aligned}
& \mathrm{C}_{\mathrm{X}}=\alpha 1 \mathrm{M} / \mathrm{P}_{\mathrm{X}} \\
& \mathrm{C}_{\mathrm{Y}}=\alpha 2 \mathrm{M} / \mathrm{P}_{\mathrm{Y}}
\end{aligned}
$$


Since $M=w L+r K+T$, we can substitute the formulas for ( $r \& w)$ from the firm's problem to obtain demand equations as functions of output prices and factor endowments.

$$
\begin{aligned}
& \mathrm{C}_{\mathrm{X}}=\alpha 1\left\{\left[\left(\mathrm{P}_{\mathrm{X}} \mathrm{Z}^{-1}\right)^{1-\beta /(\delta-\beta)}\left(\mathrm{P}_{\mathrm{Y}} \mathrm{A}^{-1}\right)^{\delta-1 /(\delta-\beta)} \mathrm{L}+\left(\mathrm{P}_{\mathrm{Y}} \mathrm{A}^{-1}\right)^{\delta /(\delta-\beta)}\left(\mathrm{P}_{\mathrm{X}} \mathrm{Z}^{-1}\right)^{-\beta /(\delta-\beta)} \mathrm{K}\right]+\mathrm{T}\right\} / \mathrm{P}_{\mathrm{X}} \\
& \mathrm{C}_{\mathrm{Y}}=\alpha 2\left\{\left[\left(\mathrm{P}_{\mathrm{X}} \mathrm{Z}^{-1}\right)^{1-\beta /(\delta-\beta)}\left(\mathrm{P}_{\mathrm{Y}} \mathrm{A}^{-1}\right)^{\delta-1 /(\delta-\beta)} \mathrm{L}+\left(\mathrm{P}_{\mathrm{Y}} \mathrm{A}^{-1}\right)^{\delta /(\delta-\beta)}\left(\mathrm{P}_{\mathrm{X}} \mathrm{Z}^{-1}\right)^{-\beta /(\delta-\beta)} \mathrm{K}\right]+\mathrm{T}\right\} / \mathrm{P}_{\mathrm{Y}}
\end{aligned}
$$

The demand equations imply that in the long run, demand for goods ( $\mathrm{X}$ and $\mathrm{Y}$ ) depends on their prices, transfers and endowments of production factors only.

\section{$\underline{\text { Comparative Statics }}$}

Below a number of comparative static exercises are conducted to determine the signs of the coefficients in the consumption equations that to be estimated in chapter four. What follows is for good (X) only because it is straightforward to do the same for good $(\mathrm{Y})$.

$\Phi_{\mathrm{X}}\left(\mathrm{P}_{\mathrm{X}}, \mathrm{P}_{\mathrm{Y}}, \mathrm{K}, \mathrm{L}, \mathrm{T}\right)=\mathrm{C}_{\mathrm{X}}\left(\mathrm{P}_{\mathrm{X}}, \mathrm{P}_{\mathrm{Y}}, \mathrm{w} \mathrm{L}+\mathrm{r} \mathrm{K}+\mathrm{T}\right)$

$\Phi_{X}\left(P_{X}, P_{Y}, K, L, T\right)=C_{X}\left(P_{X}, P_{Y}, w\left(P_{X}, P_{Y}\right) L+r\left(P_{X}, P_{Y}\right) K+T\right)$

Where $\left(\Phi_{X}\right)$ denotes the general equilibrium demand for good $(X)$, while $\left(C_{X}\right)$ denotes the Marshallian demand.

$\mathrm{d} \Phi_{\mathrm{X}} / \mathrm{d} \mathrm{P}_{\mathrm{X}}=\left(\mathrm{d} \mathrm{C}_{\mathrm{X}} / \mathrm{d} \mathrm{P}_{\mathrm{X}}\right)+\left(\partial \mathrm{C}_{\mathrm{X}} / \partial \mathrm{M}\right)\left(\partial \mathrm{M} / \partial \mathrm{P}_{\mathrm{X}}\right)$

Since $M=R, \partial M / \partial P_{X}=\partial R / \partial P_{X}=Q_{X}$

$d \Phi_{X} / d P_{X}=\left(d C_{X} / d P_{X}\right)+\left(\partial C_{X} / \partial M\right) Q_{X}$

$$
=\left(\partial \mathrm{h}_{\mathrm{X}} / \partial \mathrm{P}_{\mathrm{X}}\right)-\mathrm{C}_{\mathrm{X}}\left(\partial \mathrm{C}_{\mathrm{X}} / \partial \mathrm{M}\right)+\left(\mathrm{d} \mathrm{C}_{\mathrm{X}} / \mathrm{d} \mathrm{M}\right) \mathrm{Q}_{\mathrm{X}}
$$

Note that the first two terms on the right hand side represent the Slutsky Equation, where the first term is the substitution effect ( $\mathrm{h}$ is the Hicksian demand) and the second is the income effect. 
$\mathrm{d} \Phi_{\mathrm{X}} / \mathrm{d} \mathrm{P}_{\mathrm{X}}=\left(\partial \mathrm{h}_{\mathrm{X}} / \partial \mathrm{P}_{\mathrm{X}}\right)+\left(\mathrm{Q}_{\mathrm{X}}-\mathrm{C}_{\mathrm{X}}\right)\left(\mathrm{d} \mathrm{C}_{\mathrm{X}} / \mathrm{d} \mathrm{M}\right) \leq 0$

The first term (the own price substitution effect) is non-positive due to the concavity of the expenditure function. The second term is positive since $\left(Q_{X}-C_{X}\right)$ is positive because $(X)$ is the exportable good and $\left(d \Phi_{X} / d M\right)$ is positive assuming $(X)$ is a normal good. Overall, the sign of $\left(\mathrm{d} \Phi_{\mathrm{X}} / \mathrm{d} \mathrm{P}_{\mathrm{X}}\right)$ depends on the relative magnitudes of the substitution and income effects. However, if we ignore the income effect, the total effect is non-positive.

Next, repeat the above analysis for a change in the price of good (Y).

$\mathrm{d} \Phi_{\mathrm{X}} / \mathrm{d} \mathrm{P}_{\mathrm{Y}}=\left(\mathrm{d} \mathrm{C}_{\mathrm{X}} / \mathrm{d} \mathrm{P}_{\mathrm{Y}}\right)+\left(\partial \mathrm{C}_{\mathrm{X}} / \partial \mathrm{M}\right)\left(\partial \mathrm{M} / \partial \mathrm{P}_{\mathrm{Y}}\right)$

Since $M=R, \partial M / \partial P_{Y}=\partial R / \partial P_{Y}=Q_{Y}$

$d \Phi_{X} / d P_{Y}=\left(d C_{X} / d P_{Y}\right)+\left(\partial C_{X} / \partial M\right) Q_{Y}$

$$
\begin{aligned}
& =\left(\partial \mathrm{h}_{\mathrm{X}} / \partial \mathrm{P}_{\mathrm{Y}}\right)-\mathrm{C}_{\mathrm{Y}}\left(\partial \mathrm{C}_{\mathrm{X}} / \partial \mathrm{M}\right)+\left(\mathrm{d} \mathrm{C}_{\mathrm{X}} / \mathrm{d} \mathrm{M}\right) \mathrm{Q}_{\mathrm{Y}} \\
& =\left(\partial \mathrm{h}_{\mathrm{X}} / \partial \mathrm{P}_{\mathrm{Y}}\right)+\left(\mathrm{Q}_{\mathrm{Y}}-\mathrm{C}_{\mathrm{Y}}\right)\left(\mathrm{d} \mathrm{C}_{\mathrm{X}} / \mathrm{d} \mathrm{M}\right) \geq 0 .
\end{aligned}
$$

The first term (the cross price substitution effect) is non-negative. This can be shown by utilizing the property that the Hicksian demand function is homogeneous of degree zero. Thus, using Euler's Theorem:

$$
\begin{aligned}
& \mathrm{h}_{\mathrm{X}}=\mathrm{h}_{\mathrm{X}}\left(\mathrm{P}_{\mathrm{X}}, \mathrm{P}_{\mathrm{Y}}\right) \\
& 0=\left(\partial \mathrm{h}_{\mathrm{X}} / \partial \mathrm{P}_{\mathrm{Y}}\right) \mathrm{P}_{\mathrm{X}}+\left(\partial \mathrm{h}_{\mathrm{X}} / \partial \mathrm{P}_{\mathrm{X}}\right) \mathrm{P}_{\mathrm{Y}}
\end{aligned}
$$

The second term (in the above identity) is non-positive due to the concavity of the expenditure function, while the first term has to be non-negative in order for the identity to hold.

The second term (in $\left.d \Phi_{X} / d P_{Y}\right)$ is negative since $\left(Q_{Y}-C_{Y}\right)$ is negative because (Y) is the importable good and $\left(\mathrm{d} \Phi_{\mathrm{X}} / \mathrm{d} \mathrm{M}\right)$ is positive assuming $(\mathrm{X})$ is a normal good. 
Overall, the sign of ( $\left.d \Phi_{\mathrm{X}} / \mathrm{d} \mathrm{P}_{\mathrm{Y}}\right)$ depends on the relative magnitudes of the substitution and income effects. However, if we ignore the income effect, the total effect is nonnegative.

Now, the effect of changes in the endowments of factors of production are analyzed. First, the effect of a change in the endowment of labor (L).

$$
\begin{aligned}
\partial \Phi_{\mathrm{X}} / \partial \mathrm{L} & =\left(\partial \mathrm{C}_{\mathrm{X}} / \partial \mathrm{M}\right)(\partial \mathrm{M} / \partial \mathrm{L}) \\
& =\left(\partial \mathrm{C}_{\mathrm{X}} / \partial \mathrm{M}\right)(\partial \mathrm{R} / \partial \mathrm{L}) \\
& =\left(\partial \mathrm{C}_{\mathrm{X}} / \partial \mathrm{M}\right) \mathrm{w} \geq 0
\end{aligned}
$$

As discussed above, the first term is non-negative (assuming normality) and the second term (wage rate) is necessarily non-negative. Thus the total effect is non-negative. Second, the effect of a change in the endowment of capital (K).

$$
\begin{aligned}
\partial \Phi_{X} / \partial K & =\left(\partial C_{X} / \partial M\right)(\partial M / \partial K) \\
& =\left(\partial C_{X} / \partial M\right)(\partial R / \partial K) \\
& =\left(\partial C_{X} / \partial M\right) r \geq 0
\end{aligned}
$$

The first term is non-negative (assuming normality) and the second term (rental price of capital) is necessarily non-negative. Thus the total effect is non-negative.

\section{Linearization}

Using the implicit function theorem, the above equations can be rewritten as:

$$
\begin{aligned}
& C_{X}=H\left(P_{Y}, P_{X}, L, K, T\right) \\
& C_{Y}=H\left(P_{Y}, P_{X}, L, K, T\right)
\end{aligned}
$$


Using the above specifications, the two equations can be estimated as follows:

$$
\mathbf{C}_{\mathrm{X}}=\gamma \mathbf{0}+\gamma \mathbf{1} \mathbf{P}_{\mathrm{X}}+\gamma 2 \mathbf{P}_{\mathrm{Y}}+\gamma \mathbf{3} \mathrm{K}+\gamma 4 \mathrm{~L}+\gamma \mathbf{5} \mathrm{T}+\mathrm{e}
$$

Expected Signs: $\gamma 1 \leq 0$ (13), $\gamma 2 \geq 0$ (14), $\gamma 3 \geq 0$ (17), $\gamma 4 \geq 0$ (16) and $\gamma 5 \geq 0$.

$$
C_{Y}=\psi 0+\psi 1 P_{X}+\psi 2 P_{Y}+\psi 3 \mathbf{K}+\psi 4 L+\psi 5 T+e
$$

Expected Signs: $\psi 1 \geq 0$ (13), $\psi 2 \leq 0$ (14), $\psi 3 \geq 0$ (17), $\psi 4 \geq 0$ (16) and $\gamma 5 \geq 0$.

Where (e ) is an error term.

Note: $\mathrm{C}_{\mathrm{i}}$ is in real term since it was derived from optimization behavior.

Services consumption function is specified as an identity:

$$
C_{S}=\left(\bar{G}-\left(P_{X} G_{X}+P_{Y} G_{Y}+T\right)\right) / N P_{S}
$$




\section{(3.1.3) THE GOVERNMENT}

The government is maximizing social welfare by providing services to its citizens through a system of highly subsidized services. The government's objective is subject to a balanced budget constraint. It equates its total revenues coming from oil exports to the costs of producing public services. This includes hiring domestic citizens in the public service sector and buying goods necessary for the production of services from domestic producers.

Government revenues are exogenous in the model since they depend on two exogenous factors, namely, oil price and oil production. The former is determined by supply and demand forces in the world's market for oil, while the latter is determined by the quota system of the Organization of Petroleum Exporting Countries (OPEC). In sum, the government is both price and quantity taker. When oil revenues are determined, the government chooses its expenditures at a level that keeps its budget balanced:

$$
\mathrm{P}_{\mathrm{O}} \mathrm{Q}_{\mathrm{O}}=\overline{\mathrm{G}}
$$

Where:

$\mathrm{P}_{\mathrm{O}}$ : price of crude oil

$\mathrm{Q}_{0}$ : quantity exported of oil

The production of public services is labor intensive, no capital (or capital is negligible). The government uses labor $\left(\mathrm{L}_{\mathrm{S}}\right)$ to produce services $(\mathrm{S})$ :

$$
\mathrm{S}=\mathrm{L}_{\mathrm{S}}
$$

The marginal product of labor $\left(\mathrm{MPL}_{\mathrm{S}}\right)$ employed in the service sector is:

$\partial \mathrm{S} / \partial \mathrm{L}_{\mathrm{S}}=1$ 
Thus, if we equate the wage rate to the value marginal product of labor, this gives:

$\mathrm{w}=\mathrm{P}_{\mathrm{S}} \mathrm{MPL} \mathrm{L}_{\mathrm{S}}$

$\mathrm{w}=\mathrm{P}_{\mathrm{S}}$

Now, we can use the result above to specify the "national" revenue function:

$\mathrm{R}=\mathrm{w}\left(\mathrm{L}_{\mathrm{Y}}+\mathrm{L}_{\mathrm{X}}\right)+\mathrm{r}\left(\mathrm{K}_{\mathrm{Y}}+\mathrm{K}_{\mathrm{X}}\right)+\mathrm{P}_{\mathrm{S}} \mathrm{S}$

$\mathrm{R}=\mathrm{w}\left(\mathrm{L}_{\mathrm{Y}}+\mathrm{L}_{\mathrm{X}}\right)+\mathrm{r}\left(\mathrm{K}_{\mathrm{Y}}+\mathrm{K}_{\mathrm{X}}\right)+\mathrm{w} \mathrm{S}$

$\mathrm{R}=\mathrm{w}\left(\mathrm{L}_{\mathrm{Y}}+\mathrm{L}_{\mathrm{X}}\right)+\mathrm{r}\left(\mathrm{K}_{\mathrm{Y}}+\mathrm{K}_{\mathrm{X}}\right)+\mathrm{w} \mathrm{L}_{\mathrm{S}}$

$\mathrm{R}=\mathrm{w}\left(\mathrm{L}_{\mathrm{Y}}+\mathrm{L}_{\mathrm{X}}+\mathrm{L}_{\mathrm{S}}\right)+\mathrm{r}\left(\mathrm{K}_{\mathrm{Y}}+\mathrm{K}_{\mathrm{X}}\right)$

$\mathrm{R}=\mathrm{w} \mathrm{L}+\mathrm{rK}$

The government consumes goods ( $\mathrm{X}$ and $\mathrm{Y}$ ) during its production of services. The government is assumed to buy goods produced only by local producers; this is an indirect way of subsidizing them. Also it employs only domestic labor, which is an indirect way of redistributing oil revenues to its citizens. The government plays multiple roles in the model: exports oil, produces public services (S), hires local labor $\left(\mathrm{L}_{\mathrm{S}}\right)$, makes transfer payments $(T)$, and buys goods from local producers $\left(\mathrm{G}_{\mathrm{X}}, \mathrm{G}_{\mathrm{Y}}\right)$.

Therefore, government's expenditures are divided between the four activities it carries out:

$$
\begin{aligned}
\bar{G} & =w L_{S}+P_{X} G_{X}+P_{Y} G_{Y}+T \\
& =w_{S}+G_{X Y}+T
\end{aligned}
$$

Where $\left(\mathrm{G}_{\mathrm{XY}}\right)$ is the nominal government's budget allocated to buy goods ( $\mathrm{X}$ and $\mathrm{Y}$ ).

The government's purchases of goods $(\mathrm{X}$ and $\mathrm{Y}),\left(\mathrm{G}_{\mathrm{XY}}\right)$, are allocated as follows:

$$
\mathrm{G}_{\mathrm{X}}=\vartheta \mathrm{G}_{\mathrm{XY}} / \mathrm{P}_{\mathrm{X}} \quad \text { and } \quad \mathrm{G}_{\mathrm{Y}}=(1-\vartheta) \mathrm{G}_{\mathrm{XY}} / \mathrm{P}_{\mathrm{Y}}
$$




\section{(3.1.4) TRADE}

As stated earlier, trade between the two countries results from excess supply and excess demand in the home country. Excess demand in the home country for good (Y) creates the need for imports from the foreign country. Imports of good $(\mathrm{Y})$ are defined as follows:

$$
\begin{gathered}
\mathrm{IM}_{Y}=\mathrm{C}_{Y}+\left[(1-\vartheta) \mathrm{G}_{X Y} / \mathrm{P}_{Y}\right]-\mathrm{Q}_{Y} \quad(<0) \\
=\mathrm{C}_{Y}+\mathrm{G}_{\mathrm{Y}}-\mathrm{Q}_{\mathrm{Y}}
\end{gathered}
$$

In subsections (3.1.1 and 3.1.2) it was found that $\left(\mathrm{C}_{\mathrm{Y}} \& \mathrm{Q}_{\mathrm{Y}}\right)$ are determined by output prices and factor endowments. In subsection (3.1.3) it was argued that $\left(G_{Y}\right)$ is determined by oil revenues and consumption of good $X,\left(G_{X}\right)$. Therefore, imports of good $(\mathrm{Y})$ are determined by the difference between domestic demand and domestic supply of good (Y).

Similarly, exports of good (X) are determined by the difference between domestic output and domestic consumption of good (X):

$$
\begin{gathered}
\mathrm{EX}_{\mathrm{X}}=\mathrm{Q}_{\mathrm{X}}-\mathrm{C}_{\mathrm{X}}-\vartheta \mathrm{G}_{\mathrm{XY}} / \mathrm{P}_{\mathrm{X}} \quad(>0) \\
=\mathrm{Q}_{\mathrm{X}}-\mathrm{C}_{\mathrm{X}}-\mathrm{G}_{\mathrm{X}}
\end{gathered}
$$

Note: $\mathrm{Q}_{\mathrm{i}}, \mathrm{C}_{\mathrm{i}}$,and $\mathrm{G}_{\mathrm{i}}$ are all in real terms.

In subsections (3.1.1 and 3.1.2) we have shown that $\left(\mathrm{C}_{\mathrm{X}}\right.$ and $\left.\mathrm{Q}_{\mathrm{X}}\right)$ are determined by output prices and factor endowments. In section (3.1.3) we argued that $\left(\mathrm{G}_{\mathrm{X}}\right)$ is determined by oil revenues and consumption of good $\mathrm{Y}\left(\mathrm{G}_{\mathrm{Y}}\right)$. Therefore, exports of good (X) are simultaneously determined by supply of and demand for good (X).

It is clear that consumers are better off with trade than in the case of Autarky, i.e. no trade. That's because with imports of good (Y) they can consume their optimum level 
of this good that is composed of domestic output and imports. However, without trade, they will consume domestic output only, which is less than total demand. That is, good $(\mathrm{Y})$ is in excess demand, which may push prices up.

Producers of good $(\mathrm{X})$ are also better off with trade because they can sell their optimum output to both domestic markets and foreign markets. Without trade, they have to cut back production to keep supply equal to demand or their output is in an excess supply. Moreover, the assumption that the small country faces an infinitely elastic demand schedule for its exports means that producers of good $(\mathrm{X})$ can export whatever they produce, at the optimum. 


\section{(3.1.5) EQUILIBRIUM CONDITIONS}

As mentioned several times, an essential assumption in general equilibrium models is that all markets are in equilibrium. Therefore, in this subsection we introduce equilibrium conditions in product markets, input markets, and the balanced budget condition.

\section{a) EQULIBRIUM IN THE LABOR MARKET}

According to the Heckscher-Ohlin model, the free mobility of factors of production between sectors ensures that the markets for labor and capital are in equilibrium. That is, supply equals demand in both markets.

$$
\begin{aligned}
\text { Supply } & =\text { Demand } \\
\qquad & =L_{X}+L_{Y}+L_{S}
\end{aligned}
$$

Where:

L : total labor supply

$\mathrm{L}_{\mathrm{X}}$ : labor employed in the production of $\operatorname{good}(\mathrm{X})$

$\mathrm{L}_{\mathrm{Y}}$ : labor employed in the production of $\operatorname{good}(\mathrm{Y})$

$\mathrm{L}_{\mathrm{S}}$ : labor employed in the production of public services (S)

\section{b) EQUILIBRIUM IN THE CAPITAL MARKET}

$$
\begin{aligned}
\text { Supply } & =\text { Demand } \\
\mathrm{K} & =\mathrm{K}_{\mathrm{X}}+\mathrm{K}_{\mathrm{Y}}
\end{aligned}
$$

Where:

$\mathrm{K}$ : total capital supply

$\mathrm{K}_{\mathrm{X}}$ : capital employed in the production of $\operatorname{good}(\mathrm{X})$

$\mathrm{K}_{\mathrm{Y}}$ : capital employed in the production of $\operatorname{good}(\mathrm{Y})$ 


\section{c) EQUILIBRIUM IN THE GOODS MARKET}

Because of international trade, the market for good $(\mathrm{X})$ is in equilibrium.

Otherwise, the market would be in excess supply.

Good $(\mathrm{X}): \quad$ Supply $\quad=$ Demand

$$
\mathrm{Q}_{\mathrm{X}}=\mathrm{C}_{\mathrm{X}}+\mathrm{EX}_{\mathrm{X}}+\mathrm{G}_{\mathrm{X}}
$$

Where:

$\mathrm{Q}_{\mathrm{X}}$ : domestic output of good (X)

$\mathrm{C}_{\mathrm{X}}$ : household consumption of $\operatorname{good}(\mathrm{X})$

$\mathrm{EX}_{\mathrm{X}}$ : exports to the foreign country of $\operatorname{good}(\mathrm{X})$

$\mathrm{G}_{\mathrm{X}}$ : government consumption of $\operatorname{good}(\mathrm{X})$

Because of international trade, the market for good (Y) is, also, in equilibrium.

Otherwise, the market would be in excess demand.

Good (Y): $\quad$ Supply = Demand

$$
\mathrm{Q}_{\mathrm{Y}}+\mathrm{IM}_{\mathrm{Y}}=\mathrm{C}_{\mathrm{Y}}+\mathrm{G}_{\mathrm{Y}}
$$

Where:

QY : domestic output of good (Y)

$\mathrm{C}_{\mathrm{Y}}$ : household consumption of $\operatorname{good}(\mathrm{Y})$

IM $_{Y}$ : home country's imports of $\operatorname{good}(\mathrm{Y})$

$\mathrm{G}_{\mathrm{Y}}$ : government consumption of $\operatorname{good}(\mathrm{Y})$

\section{d) BALANCED GOVERNMENT BUDGET}

The final condition is that of the balanced government budget.

Oil Revenues $=$ Government Expenditure

$$
\overline{\mathrm{P}}_{\mathrm{O}} \overline{\mathrm{Q}}_{\mathrm{O}}=\overline{\mathrm{G}}
$$

Where:

$\mathrm{P}_{\mathrm{O}}$ : price of crude oil

$\mathrm{Q}_{\mathrm{O}}$ : quantity of oil exported

$\mathrm{G}$ : government expenditure 


\section{(3.2) TRADE WITH TARIFFS}

The previous section derived the model's supply and demand equations without mentioning the presence of distortionary protection policies used by either country. This section and the next two sections will take into account trade distortions that exist in the real world. This section will modify the original model by incorporating protection policies, namely, import tariffs by both countries. The objective is to investigate their effects on prices of goods (X and $\mathrm{Y}$ ), which in turn affect all the relevant functions in the home country. Moreover, the new specifications are used in the next chapter in estimating the effects of the WTO rules that require member countries to reduce their protection barriers.

A good starting point in the analysis of tariffs is to examine prices of the tradable goods $(\mathrm{X}$ and $\mathrm{Y})$. First, begin with the price of $\operatorname{good}(\mathrm{Y})$. The price $\left(\mathrm{P}_{\mathrm{Y}}\right)$ is the price paid by the consumers of good (Y) in the home country and already includes import tariffs by the home country. The world price of $\operatorname{good}(\mathrm{Y})$ is $\left(\mathrm{P}^{*} \mathrm{Y}\right)$, which the foreign country charges for its exports.

Now, consider an import (ad valorem) tariff by the home country at a rate $\left(\tau_{\mathrm{Y}}\right)$ on imports of $\operatorname{good}(\mathrm{Y})$. The price of $\operatorname{good}(\mathrm{Y})$ in the home country becomes:

$$
\mathrm{P}_{\mathrm{Y}}=\mathrm{P}^{*}{ }_{\mathrm{Y}}\left(1+\tau_{\mathrm{Y}}\right)
$$

Where:

$\mathrm{P}_{\mathrm{Y}}:$ domestic price of good $(\mathrm{Y})$ in the home country

$\mathrm{P}^{*}{ }_{\mathrm{Y}}$ : world price of $\operatorname{good}(\mathrm{Y})$

$\tau_{\mathrm{Y}}$ : tariff rate on imports of $\operatorname{good}(\mathrm{Y})$ by the home country 
Since the tariff rate is greater than zero, then the domestic price must be greater than the world price. Domestic producers take advantage of the price increase induced by the tariff and they, too, raise their price to equal the world price plus the tariff. In other words, they free ride. The government collects tariff revenues and returns them to the households as transfer payments. A common assumption in the international trade literature is that the government collects tariff revenues costlessly. As a result, the households' income is not affected by the tariff since tariff revenues are fully returned to them as transfers. Thus, there is no redistribution effect of income from the tariff.

A similar analysis is applied to the effect on the price of good (X) of a tariff imposed by the foreign country at a rate $\left(\tau^{*}\right)$.

The domestic price of $(\mathrm{X})$ in the foreign country equals to:

$\mathrm{P}^{*}{ }_{\mathrm{X}}=\mathrm{P}_{\mathrm{X}}\left(1+\tau_{\mathrm{X}}^{*}\right)$

Where:

$\mathrm{P}^{*}{ }_{\mathrm{X}}$ : domestic price of good $(\mathrm{X})$ in the foreign country

$\mathrm{P}_{\mathrm{X}} \quad$ : world price of good $(\mathrm{X})$

$\tau^{*}{ }_{\mathrm{X}} \quad$ : tariff rate on good $(\mathrm{X})$ by the foreign country

In what follows, the above effects are incorporated into the original model, which has to be modified to account for tariffs. First, note that tariffs have no effect on the domestic price of $(\mathrm{X})$ in the home country, so it remains $\left(\mathrm{P}_{\mathrm{X}}\right)$. Second, all the supply and demand equations for the home country that include $\left(\mathrm{P}_{\mathrm{Y}}\right)$ have to be modified since $\left(\mathrm{P}_{\mathrm{Y}}\right)$ has been modified to: $\mathrm{P}_{\mathrm{Y}}=\mathrm{P}_{\mathrm{Y}}^{*}\left(1+\tau_{\mathrm{Y}}\right)$. Third, the national revenue equation has to 
be modified to include tariff revenues collected by the government. These (tariff)

revenues equal:

$$
\mathrm{R}_{\mathrm{t}}=\mathrm{P}^{*}{ }_{\mathrm{Y}} \tau_{\mathrm{Y}} \mathrm{IM}_{\mathrm{Y}}
$$

Or $\quad \mathrm{R}_{\mathrm{t}}=\left(\left(\mathrm{P}_{\mathrm{Y}}\right) /\left(1+\tau_{\mathrm{Y}}\right)\right) \tau_{\mathrm{Y}} \mathrm{IM}_{\mathrm{Y}}$

Below are the modified equations that to be estimated in the next chapter to obtain parameters that to be used in simulation exercises. The objective is to obtain estimates of the potential economic effects of the WTO on supply, demand, welfare and terms of trade in the home country.

$$
\begin{aligned}
& \mathbf{Q X}_{\mathrm{X}}=\phi 0+\phi 1 \mathbf{P}^{*}{ }_{\mathrm{Y}}\left(1+\tau_{\mathrm{Y}}\right)+\phi 2 \mathbf{P}_{\mathrm{X}}+\phi 3 \mathrm{~L}+\phi 4 \mathrm{~K}+\mathrm{e} \\
& \mathbf{Q}_{\mathbf{Y}}=\varphi \mathbf{0}+\varphi 1 \mathbf{P}_{\mathbf{Y}}^{*}\left(1+\tau_{\mathrm{Y}}\right)+\varphi 2 \mathbf{P}_{\mathbf{X}}+\varphi \mathbf{3} \mathbf{L}+\varphi 4 \mathbf{K}+\mathrm{e} \\
& \mathbf{L}_{\mathbf{Y}}=\xi_{0}+\xi_{1} \mathbf{P}^{*}{ }_{\mathbf{Y}}\left(1+\tau_{\mathbf{Y}}\right)+\xi_{2} \mathbf{P}_{\mathbf{X}}+\xi_{3} \mathbf{L}+\xi_{4} \mathbf{K}+\mathbf{e} \\
& K_{Y}=\mu 0+\mu 1 P_{Y}^{*}\left(1+\tau_{Y}\right)+\mu 2 P_{X}+\mu 3 \mathbf{L}+\mu 4 K+e \\
& \mathbf{L}_{\mathbf{X}}=\Omega 0+\Omega 1 \mathbf{P}^{*}{ }_{\mathbf{Y}}\left(1+\tau_{\mathrm{Y}}\right)+\Omega 2 \mathbf{P}_{\mathrm{X}}+\Omega 3 \mathbf{L}+\Omega 4 \mathrm{~K}+\mathrm{e} \\
& \mathbf{K}_{\mathbf{X}}=\theta 0+\theta 1 \mathbf{P}^{*}{ }_{\mathbf{Y}}\left(1+\tau_{\mathrm{Y}}\right)+\theta 2 \mathbf{P}_{\mathbf{X}}+\theta 3 \mathbf{L}+\theta 4 \mathbf{K}+\mathbf{e} \\
& \mathrm{C}_{\mathrm{X}}=\gamma \mathbf{0}+\gamma 1 \mathrm{P}^{*}{ }_{\mathrm{Y}}\left(1+\tau_{\mathrm{Y}}\right)+\gamma 2 \mathrm{P}_{\mathrm{X}}+\gamma 3 \mathrm{~L}+\gamma 4 \mathrm{~K}+\gamma \mathbf{5} \mathrm{T}+\mathrm{e} \\
& \mathbf{C}_{\mathbf{Y}}=\psi \mathbf{0}+\psi 1 \mathbf{P}_{\mathbf{Y}}^{*}\left(1+\tau_{\mathrm{Y}}\right)+\psi 2 \mathbf{P}_{\mathbf{X}}+\psi 3 \mathbf{L}+\psi 4 \mathbf{K}+\psi 5 \mathbf{T}+\mathrm{e} \\
& \mathbf{R}=\mathbf{w} \mathbf{L}+\mathbf{r} \mathbf{K}+\mathbf{P}_{\mathbf{Y}}^{*} \tau_{\mathbf{Y}} \mathbf{I} \mathbf{M}_{\mathbf{Y}} \\
& \overline{\mathbf{G}}=\mathbf{P}_{\mathbf{O}} \mathbf{Q}_{\mathbf{o}}+\mathbf{P}_{\mathbf{Y}}^{*} \tau_{\mathbf{Y}} \mathbf{I} \mathbf{M}_{\mathbf{Y}} \\
& \mathbf{G}_{\mathbf{Y}}=(1-\vartheta) \mathbf{G}_{\mathbf{X Y}} / \mathbf{P}^{*}{ }_{\mathbf{Y}}\left(1+\tau_{\mathrm{Y}}\right) \\
& I_{M_{Y}}=C_{Y}+(1-\vartheta) G_{X Y} / P^{*}\left(1+\tau_{Y}\right)-Q_{Y}
\end{aligned}
$$




\section{(3.3) ECONOMIC EFFECTS OF TARIFFS}

The imposition of the import tariff by the home country has multiple effects on the economy. First, there is an effect on the terms of trade $\left(\mathrm{P}_{\mathrm{X}} / \mathrm{P}_{\mathrm{Y}}\right)$, it decreases. The tariff on $(\mathrm{Y})$ increases the relative price of $(\mathrm{Y})$ which, according to Stolper-Samuelson theorem, increases the return on the resource used more intensively in its production. Given the mobility of resources between sectors, capital and labor is diverted to the production of the protected good, (Y). Second, assuming normality, consumption of (Y) falls as its price increases. Thus, imports of $(\mathrm{Y})$ decrease. However, the consumption of good (X) may increase or decrease, depending on the magnitudes of the substitution and income effects and which one dominates the other. Third, there is a welfare loss due to the imposition of the tariff that can be decomposed into consumption loss and production loss. The consumption loss arises from the distortion of prices facing the household which reduces its consumption of good $(\mathrm{Y})$, as mentioned above. The production loss results from the distortion of prices facing producers, which shifts resources from producing $(\mathrm{X})$ to producing $(\mathrm{Y})$.

Trade Economists are interested in the measurement of the economic effects of tariffs. First, it is important to quantify the effects of the tariff on the supply of output of the two goods ( $\mathrm{X}$ and $\mathrm{Y})$ and on demand for both consumption of the two goods and the demand for factors of production (capital and labor). Second, measuring the effects on the balance of trade that results from the change in the terms of trade (relative prices) and supply and demand is necessary. Finally, measuring the welfare loss that results from the 
imposition of the tariff on imports needs to be accomplished. Below is an algebraic derivation of the welfare effect of the tariff using two approaches: The balance of trade function approach, which is derived from the income expenditure identity, and the direct welfare evaluation approach, which is derived from the expenditure function.

\section{(3.3.1) THE BALANCE OF TRADE FUNCTION}

A widely used approach in the international trade literature to measure the welfare effect of tariffs is the balance of trade function approach, which is derived from the income-expenditure identity. We assume that import tariffs are the only distortions in the economy. For derivations and applications of the expenditure function see: Diamond and McFadden (1974), Dixit (1975), Kay (1980), Small and Rosen (1981), Hausman (1981), Marion and Svensson (1986), Llyod and Schweinberger (1988), Vousden (1990), and Thurman (1993). Below we derive a measure of the welfare effect that results from a change in either/both tariff rates or/and world prices. The derivation is based on the expenditure and the balance of trade functions.

Define the expenditure function as:

$\mathrm{E}(\mathrm{P}, \mathrm{u})=\min \{\mathrm{PC}: \mathrm{U}(\mathrm{C})=\mathrm{u}\}$

By Shephard's lemma, the compensated demand for consumption can be obtained by taking the derivative of the expenditure function with respect to the price of output:

$\partial \mathrm{E}(\mathrm{P}, \mathrm{u}) / \partial \mathrm{P}_{\mathrm{i}}=\mathrm{E}_{\mathrm{p}}=\mathrm{C}(\mathrm{P}, \mathrm{u})$ 
The linear homogeneity of $\mathrm{E}$ with respect to price implies (by Euler's theorem) that:

$\sum \mathrm{PE}_{\mathrm{p}}=\mathrm{E}$

and

$\sum P E_{p u}=E_{u}$

Next, define the national income (revenue or GDP) function as

$\mathrm{R}(\mathrm{P}, \mathrm{v})=\max \{\mathrm{PQ}: \Phi(\mathrm{Q}, \mathrm{v})=0\}$

Where $\Phi(\mathrm{Q}, \mathrm{v})$ is the economy's production frontier and "v" is a vector of inputs.

Using the envelope theorem, output can be determined by taking the partial derivative of the national income function with respect to the price of output:

$\partial \mathrm{R}(\mathrm{P}, \mathrm{v}) / \partial \mathrm{P}=\mathrm{R}_{\mathrm{p}}=\mathrm{Q}(\mathrm{P}, \mathrm{v})$

and using Euler's theorem,

$$
\sum \mathrm{PR}_{\mathrm{p}}=\mathrm{R}
$$

The economy's budget constraint is:

$E(P, u)=R(P, v)+\tau p^{*} I M$

Where $\mathrm{IM}=\left[\mathrm{E}_{\mathrm{p}}-\mathrm{R}_{\mathrm{p}}\right]$ is the compensated demand for imports and $(\tau)$ is the tariff rate. Note that $(\mathrm{P})$ is defined as $\left(\mathrm{P}^{*}(1+\tau)\right)$. Totally differentiate (5)

$E_{p} d P+E_{u} d u=R_{p} d P+\tau I M d P^{*}+P^{*} I M d \tau+\tau P^{*} d I M$

Take $\left(\mathrm{R}_{\mathrm{p}} \mathrm{dP}\right)$ to the left to define (IM dP)

$I M d P+E_{u} d u=\tau I M d P^{*}+P^{*} I M d \tau+\tau P^{*} d I M$

$E_{u} d u=\tau I M d P^{*}+P^{*} I M d \tau+\tau P^{*} d I M-I M d P$

$E_{u} d u=\tau \operatorname{IM~dP}^{*}+P^{*} \operatorname{IM} d \tau+\tau P^{*} d \operatorname{IM}-\operatorname{IM}\left[P^{*} d \tau+(1+\tau) d p^{*}\right]$ 
$\mathrm{E}_{\mathrm{u}} \mathrm{du}=[\tau \mathrm{IM}-\mathrm{IM}(1+\tau)] \mathrm{dP}^{*}+\tau \mathrm{P}^{*} \mathrm{dIM}$

$E_{u} d u=-I M d P^{*}+\tau P^{*} d I M$

Multiply the second term on the right hand side by ((dp/dp) (IM/IM) (P/P)) to

obtain the compensated elasticity of demand for imports $\left(\eta^{\mathrm{C}}\right)$,

$E_{u} d u=-I M d P^{*}+\tau P^{*}(d I M / d P)(P / I M)(I M / P) d P$

$\mathrm{E}_{\mathrm{u}} \mathrm{du}=-\mathrm{IM} d \mathrm{P}^{*}+\tau \eta^{\mathrm{C}} \mathrm{P}^{*} \mathrm{IM}(\mathrm{dP} / \mathrm{P})$

Multiply the first term on the right hand side by $\left(\mathrm{P}^{*} / \mathrm{P}^{*}\right)$ to express the change in the world price as a percentage rate, this gives the expression for the equivalent variation using the balance of trade function:

$E_{u} d u=-I M P^{*}\left(d P^{*} / P^{*}\right)+\tau \eta^{C} P^{*} I M(d P / P)$

Equation (7) provides an exact measure of the welfare effect that results from a change in the world price of the importable good or a change in the tariff rate. For example, a percentage change in the tariff rate is captured by the percentage change in the domestic price $(\mathrm{dP} / \mathrm{P})$. However, a percentage change in the world price is captured by changes in both, the percentage change in the world price term $\left(\mathrm{dP}^{*} / \mathrm{P}^{*}\right)$ and the percentage change in domestic price term $(\mathrm{dP} / \mathrm{P})$. The latter effect results from the price transmission assumption, which comes from the assumption that the small country is a price taker, therefore the domestic price must equal the world price. In addition, equation (7) can also be used to measure the welfare effect of export taxes, which have the same effect as import tariffs, according to Lerner's Theorem. 
Equation (7) can be numerically measured since all the right hand side terms can be easily calculated, one term that needs some effort is the own price elasticity of the compensated demand for imports $\left(\eta^{\mathrm{C}}\right)$. As it was shown above, $\left(\eta^{\mathrm{C}}\right)$ can be found by taking the second derivatives of the expenditure and revenue functions and then multiplying them by (P/IM). Empirically, however, researchers estimate $\left(\eta^{C}\right)$, instead of deriving it theoretically, as follows. Using a log-linear function, regress imports on import prices and economic activity variable (GDP) where the coefficients of price and income are price and income elasticities, respectively. However, price elasticity obtained above is the uncompensated (Marshallian) price elasticity but what we need is the compensated (Hicksian) price elasticity, which can be obtained from the Slutsky equation:

$\partial \mathrm{IM}^{\mathrm{U}} / \partial \mathrm{p}=\partial \mathrm{IM}^{\mathrm{C}} / \partial \mathrm{p}-\mathrm{IM} \partial \mathrm{IM}^{\mathrm{U}} / \partial \mathrm{R}$

Where superscripts ( $\mathrm{U}$ and $\mathrm{C}$ ) correspond to uncompensated and compensated demand for imports respectively, while $\mathrm{R}$ is income.

After some algebraic manipulations (see Appendix (2) for details), the compensated elasticity is specified as follows:

$\eta^{\mathrm{C}}=\eta^{\mathrm{U}}+\psi \eta_{\mathrm{R}}$

Where $\psi$ is the share of expenditure on the importable good in total expenditure and $\eta^{R}$ is the income elasticity. Since the second term on the right hand side is necessarily positive (assuming normality), it is obvious that $\eta^{\mathrm{C}}$ must exceed $\eta^{\mathrm{U}}$, in absolute value. 
Finally, the welfare effect (equation (7)) can be measured also as a percentage of income (GDP) by dividing both sides by R;

$E_{u} d u / R=-I M P^{*} / R\left(d P^{*} / P^{*}\right)+\tau \eta^{C} P^{*} I M / R(d P / P)$

$\mathbf{E}_{\mathbf{u}} \mathbf{d u} / \mathbf{R}=-\Omega\left(\mathrm{dP}^{*} / \mathbf{P}^{*}\right)+\Omega \tau \eta^{\mathrm{C}}(\mathrm{dP} / \mathbf{P})$

Where $\Omega=\mathrm{IM} \mathrm{P}^{*} / \mathrm{R}$

\section{(3.3.2) DIRECT WELFARE EVALUATION}

There are two measures of direct evaluation of welfare, namely, the Compensating Variation (CV) and the Equivalent Variation (EV). Shoven and Whalley (1984) and Brown and Whalley (1980) have estimated the welfare effect of reducing tariffs using the $\mathrm{CV}$ and EV. Their results show that the two measures give close estimates. Therefore, I decided to use the EV in estimating the welfare effect.

Welfare economists commonly use the Equivalent variation (EV) as a measure of welfare effect of tax and tariff policies. The EV is defined as the amount of income that can be taken away from the consumer, at the initial prices, to make him as well off as he would be at the new prices. Below is a derivation of the EV (based on Vousden, 1990), for the case of a change in the tariff rate.

$$
E V=E\left(p_{1}, u_{1}\right)-E\left(p_{0}, u_{1}\right)-\left[g\left(p_{1}, v\right)-g\left(p_{0}, v\right)\right]-\left[T R\left(p_{1}, u_{1}\right)-T R\left(p_{0}, u_{1}\right)\right]
$$

Where TR(.) is tariff revenue and subscripts $(0 \& 1)$ denote before and after the change in the tariff rate, respectively. 
Using (5), (10) can be rearranged to:

$$
\mathrm{EV}=\mathrm{E}\left(\mathrm{p}_{0}, \mathrm{u}_{0}\right)-\mathrm{E}\left(\mathrm{p}_{0}, \mathrm{u}_{1}\right)
$$

Define " $p$ " as the price vector under the current tariff regime and " $p$ " as the free trade price vector. Using Taylor Series expansion of (10) about $p=p^{*}$,

$$
\begin{aligned}
& E V=-0.5 \sum \sum \mathrm{S}_{\text {PiPj }} \mathrm{t}_{\mathrm{i}} \mathrm{t}_{\mathrm{j}} \\
& \mathrm{EV}=-0.5 \sum \sum\left[\partial \mathrm{C}_{\mathrm{i}}\left(\mathrm{p}^{*}, \mathrm{u}_{1}\right) / \partial \mathrm{p}_{\mathrm{j}}-\partial \mathrm{Q}_{\mathrm{i}}\left(\mathrm{p}^{*}\right) / \partial \mathrm{p}_{\mathrm{j}}\right] \mathrm{t}_{\mathrm{i}} \mathrm{t}_{\mathrm{j}}
\end{aligned}
$$

We can rearrange (12) to find EV as a proportion of GDP (R),

$$
E V / R=-0.5 \sum \sum r_{i} r_{j} \eta_{i j} \alpha_{i}
$$

Where :

$\mathrm{r}_{\mathrm{i}}=$ tariff rate $=\left(\mathrm{p}-\mathrm{p}^{*}\right) / \mathrm{p}=\mathrm{t}_{\mathrm{i}} / \mathrm{p}_{\mathrm{i}}$

$\eta_{\mathrm{ij}}=$ elasticity of demand for imports of good " $\mathrm{i}$ ” with respect to price of good " $\mathrm{j}$ "

$\alpha_{i}=$ share of imports of good "i" in GDP $=P_{i} I_{M} / R$

Next, the case of the welfare effects of reducing tariffs must be considered. To do so, totally differentiate (10),

$$
\begin{aligned}
& \mathrm{dEV} / \mathrm{R}=-1 / \mathrm{Y} \sum \sum \mathrm{t}_{\mathrm{i}} \mathrm{S}_{\mathrm{PiPj}} \mathrm{dt}_{\mathrm{i}} \\
& \mathrm{dEV} / \mathrm{R}=-\sum \sum \mathrm{r}_{\mathrm{i}} \eta_{\mathrm{ij}} \alpha_{\mathrm{i}} \mathrm{dt}_{\mathrm{i}} / \mathrm{p}_{\mathrm{j}}
\end{aligned}
$$

Now, suppose that all tariffs were reduced by k,

$$
\mathrm{dt}_{\mathrm{i}}=-\mathrm{k} \mathrm{t}_{\mathrm{i}} \quad \text { for all } \mathrm{k}>0
$$

Thus, the final expression for the welfare gain from reducing tariffs as a proportion of GDP, for the $\mathrm{n}$ good case, is given in equation (15):

$$
\mathrm{d} E V / R=\mathrm{k} \sum \sum \mathrm{r}_{\mathrm{i}} \mathrm{r}_{\mathrm{j}} \eta_{\mathrm{ij}} \alpha_{\mathrm{i}}
$$


The above analysis was based on the $\mathrm{n}$ (import) good case, however, our model is based on the one (import) good case. Therefore, equations (13) and (15) have to be modified for the one import good case as follows:

Equation (13) has to be:

$E V / R=-0.5 r^{2} \eta \alpha$

and equation (15) has to be:

$\mathrm{dEV} / \mathbf{R}=0.5 \mathrm{k} \eta \alpha \mathbf{r}_{0}\left(\mathbf{r}_{1}+\mathbf{r}_{0}\right) /\left(1-\mathbf{r}_{1}\right)$

Note that (13') is a special case of (15'), that is when $k=1$ which corresponds to the case of full trade liberalization ( $\mathrm{t}=0$ ), as a result $\mathrm{r}_{1}=0$. 


\section{(3.4) ECONOMIC EFFECTS OF OTHER WTO AGREEMENTS}

The last two sections have discussed the economic effects of reducing tariffs on welfare and supply and demand functions in the home country because tariff reduction is one the most significant agreements signed by WTO members. This reduction is intended to reduce trade barriers and to smooth the flow of international trade. However, tariff reduction agreement is only one of many agreements signed by WTO members to improve the access of exporters to the world markets. This section discusses and investigates the effects of some of the WTO agreements that are expected to have some economic effect on the home country, Kuwait.

Production and export subsidies: The government of Kuwait provides domestic producers with production support that is prohibited under the WTO agreement on subsidies. Given the small country assumption (i.e. price taking for exports and imports), what would be the effect of eliminating the subsidies on both domestic producers and consumers? For producers, a reduction in subsidies will increase the cost of production but will not increase prices because domestic firms are price takers. Even if they increased their prices they would lose their share in the domestic and the international markets. Therefore, it is expected that producers either cut their costs to stay in the market or go out of business. Similarly, consumers will not be affected since prices will remain unchanged.

Anti-dumping Agreement: A common complaint by domestic producers in Kuwait is that foreign suppliers sell their products in the Kuwaiti market at prices lower than those charged in the producing country's market. Enforcement of the Antidumping Agreement would result in eliminating the dumping practice, which means that import 
prices may go up as a result. The increase in import prices will have a similar effect to that of imposing an import tariff or import quota. That is, domestic producers benefit from the price increase since they can charge higher prices for their products, while consumers will incur a welfare loss because they will pay higher prices. The terms of trade will decline and imports will decline as well. This possibility is analyzed and economic effects is quantified in a similar way to that of tariffs.

Government Procurement Agreement: This agreement prohibits governments from discriminating against foreign suppliers by favoring domestic producers. This discriminatory behavior is widely practiced by governments. An enforcement of this agreement would reduce the government's purchases from domestic producers and may or may not increase total imports. Here we hypothesize the possibility that the domestic government is in fact discriminating against foreigners, the question is what would be the effect on imports? Imports as defined in section (3.1.4), represent the excess demand for the importable good $(\mathrm{Y})$ :

Imports of $\operatorname{good}(\mathrm{Y})=\mathrm{CY}+\mathrm{GY}-\mathrm{QY}$

If the government reduced its consumption of the domestic output of good (Y) and increased its consumption of imports of good (Y), this will have no effect on the volume of imports since the reduction in the government's consumption of domestic output is offset by an increase by the households' consumption. Similarly, the increase in the government's imports is offset by a reduction in the households' imports. Thus, the net effect on the demand for domestic output and imports is zero. This result is valid only under the assumption of homogeneity of the imported and domestic goods. 
The effect on government's purchases of good $(\mathrm{X})$ is different. By assumption, good $(\mathrm{X})$ is only domestically produced. If the government uses its purchases of $(\mathrm{X})$ as a way to subsidize domestic producers this is subjected to the Government Procurement Agreement and the Subsidies and Countervailing Agreement as well and these purchases are prohibited. In this case there is an effect on exports of good (X), which were defined in section (3.1.4) as the excess supply of good (X):

Exports of $(\mathrm{X})=\mathrm{QX}_{\mathrm{X}}-\mathrm{C}_{\mathrm{X}}-\mathrm{G}_{\mathrm{X}} \quad(>0)$

The reduction in $\mathrm{G}_{\mathrm{X}}$ will increase the excess supply and therefore increases exports, assuming the country faces infinitely elastic demand schedule for its exports.

Finally, a potential consequence of the implementation of the WTO agreements, is a reduction in world prices of merchandise. The reduction in prices may result from some or all of the following reasons:

1) The reduction in tariffs on capital goods, crude materials and services would reduce the costs of production and prices may fall as a result.

2) The opening of new markets for exports would allow firms to take advantage of economies of scale as they increase output and capacity. Again, costs and prices may fall. 3) The increase in competition, as more suppliers compete in a given market, reduces prices as suggested by economic theory.

4) The Agreement on Textiles and Clothing, which will phase out the Multifibre Arrangement that has restricted exports of textile since 1974, will reduce textile prices as quota restrictions imposed by developed countries on imports from developing countries is eliminated. Competition from low cost products from developing countries with high cost products from developed countries will put a downward pressure on textile and 
clothing prices.

Overall, it is expected that consumers around the world will enjoy lower prices of goods as a result of the enforcement of the WTO rules of trade. The decline in world prices is analyzed in a similar way to that of a tariff reduction. 


\section{CHAPTER (4)}

\section{ESTIMATION}

\section{INTRODUCTION}

This chapter is divided into three main sections. First, section (4.1) briefly discusses the data that is used in estimation and the problems that were faced. Second, section (4.2) estimates the demand and supply equations obtained in chapter three (section 3.1). These equations are estimated under the current regime with no changes in either trade policy or external shocks. Finally, in section (4.3), welfare effects of the current regime are estimated. 


\section{(4.1) DATA}

A common problem facing empirical studies using time-series in general and studies dealing with Less Developed Countries (LDCs) is the availability of data. The data availability problem is divided into three main branches; length, depth and reliability.

\section{(4.1.1) LENGTH}

It is almost impossible to find times-series data for LDCs for periods before the 1950s. This leaves researchers dealing with these countries with not enough data to get concrete and reliable results. A survey by Khayum (1991) of thirteen econometric models of LDCs that use time-series data shows that the number of observations used in these studies is between eight (Carter, 1970) and twenty two (Central Bureau of Statistics, 1984; Paul, 1970). A summary of these models is provided in table (24) in Appendix (5). This study is not an exception, the earliest time series data for Kuwait begin in 1960 . However, trade data, which are essential to this study, start from 1969. The latest data available are for the year 1999. This leaves us with only thirty one annual observations. In this study, twelve studies of Kuwait that used time-series data were surveyed. It was found that the number of "annual" observations was between seven (Crockett and Evans, 1980) and twenty eight (Abdulghani, 1991). Other studies that use "quarterly" data have observations between twenty four (Moosa, 1986) and forty four (Fadil, 1989; Perera, 1994). Table (25) in Appendix (6) provides a summary of these studies. 


\section{(4.1.2) DEPTH}

By depth we mean the disaggregation of the data. LDCs' data usually cover main economic indicators only, while in developed countries each main economic indicator is disaggregated into a number of detailed indicators. This study faced also the data depth problem.

First, private consumption data are available in one aggregated series. However, what was needed were disaggregated series for the different types of consumption (e.g. food, manufacturing and services). Since the emphasis of the study is on two types of manufactured goods, a way had to be found to disaggregate consumption of manufactured goods into consumption of the importable good (Y) and the exportable good (X). Regarding good (Y), there are data sets available for domestic production and imports. These two sets can be used to find a data set for consumption. Assuming that consumption of good (Y) equals domestic production plus imports, consumption was found by adding domestic production and imports. Regarding good $(\mathrm{X})$, the available data sets cover domestic production and exports. These two series were used to find a data set for consumption. This was done by assuming that domestic production is divided between domestic consumption and exports, no change in inventories. Consumption of good (X) was found by subtracting exports from domestic production. Next, the consumption of goods ( $\mathrm{X}$ and $\mathrm{Y}$ ) was added to find total consumption. The shares of the goods ( $\mathrm{X}$ and $\mathrm{Y}$ ) were $3.4 \%$ and $96.6 \%$, respectively.

Second, government consumption data are available in more detail than private consumption. However, consumption of manufactured goods ( $\mathrm{X}$ and $\mathrm{Y}$ ) is available in one 
series only. To disaggregate this series, it was assumed that the government consumes the same shares of the two goods as the household.

Third, fixed capital data have two problems. First, no data were available for the capital stock, only annual investment data. The latter was used to generate capital stock using the capital evolution equation, which is a fundamental equation in growth and real business cycle models in explaining the growth in capital stock. Here the equation is used in obtaining approximations for the capital stock in Kuwait during the sample period. This was also done by Kwack (1986) in estimating the capital stock in Korea.

The earliest available investment expenditure data are for 1960, so it was assumed that the initial capital stock is the same as the amount of investment in that year. This assumption is not unreasonable because Kuwait started exporting oil in the early fifties of the last century and used oil revenues in developing a modern economy.

Next, I applied the capital evolution equation for the rest of the sample period as follows:

$\mathrm{K}_{\mathrm{t}}=\mathrm{I}_{\mathrm{t}}+(1-\delta) \mathrm{K}_{\mathrm{t}-1}$

Where $\mathrm{K}$ is capital, $\delta$ is the depreciation rate, $\mathrm{I}$ is investment and subscript $\mathrm{t}$ stands for time. Following studies in the real business cycle literature, it was assumed that the depreciation rate is $10 \%$ [Backus, Kehoe and Kydland (1992, 1993, 1994), Hansen (1985), Kydland and Prescott (1982) and Van Wincoop (1996)].

The second problem (with capital) is the destruction of a significant share of the capital stock during the Iraqi invasion in 1990-91. Unfortunately, no estimates exist about what percentage of capital was destroyed during that period. To get an approximation of 
the damage to capital, it was assumed that the percentage destruction of capital equals the percentage reduction in non-oil GDP during the 1990-91 period. This makes sense because capital is used in the production of domestic goods and services, therefore destruction of capital would result in a decline in non-oil GDP by approximately the same portion. Non-oil GDP declined by $26.2 \%$ in 1990 and by $13.4 \%$ in 1991 . In addition, another approximation was specified for rebuilding capital following the war in 1992 . Again, non-oil GDP was used as approximation, which increased by 44\% in 1992 . Capital was assumed to increase proportionally.

\section{(4.1.3) RELIABILITY}

Another problem that is more common in LDCs is reliability. When data sets are unreliable they suffer from measurement errors and different government institutions give different numbers for the same economic indicator. Again, Kuwait is not an exception. There was no way to avoid this problem, but to mitigate, the available data from the most reliable source, the Ministry of Planning, was used. 


\section{(4.2) ESTIMATING THE MODEL}

In chapter three (section 3.1) supply and demand equations were derived by solving the household and the firm optimization problems. It was shown that these equations could be specified as functions of output prices and endowments of factors of production. This section will estimate these equations using real annual data (in 1994 prices) for Kuwait for the period between 1969 and 1999. The choice of the estimation technique is critical because the coefficients that are obtained in this section is used in chapter five in a number of simulation exercises. Below is a discussion of and a comparison among the three techniques considered, including a justification of the chosen technique.

Ordinary Least Squares: This technique is widely used because of its simplicity and attractive properties that make it a popular and powerful tool in regression analysis (Gujarati, 1995). The Ordinary Least Squares (OLS) technique produces estimates that are known as Best Linear Unbiased Estimates (BLUE). However, OLS is based on restrictive assumptions that are difficult to meet in applied work. One assumption is that if a system of equations is estimated simultaneously, all the explanatory variables have to be exogenous. Otherwise, the problem of simultaneous equations arises. Fortunately, in the system that is being used in this study all the explanatory variables are exogenous. Another assumption is that the estimation's errors between the equations of the model are uncorrelated. This assumption may be violated in the current model since almost the same explanatory variables are used in all the equations (except the lagged dependent variables) making the possibility of correlation between errors across equations 
significant. Therefore, the estimates obtained from OLS may be biased and inefficient, therefore an alternative technique should be used.

Seemingly Unrelated Regression: If the errors between the model's equations are correlated, as may be the case in the current model, then this technique is more appropriate than OLS. The Seemingly Unrelated Regression (SUR) technique, also known as the multivariate regression, or Zellner's method, obtains estimates of the parameters of the model by working recursively, accounting for heteroskedasticity, and contemporaneous correlation in the errors across equations. Unfortunately, when SUR was tested empirically, there were signs of serial correlation in the errors that needed to be corrected. One way of correction is to use a procedure known as the "Cochrane-Orcutt two-step procedure" developed by Chochrane and Orcutt (1949). This procedure consists of series of iterations, each of which produces a better estimate of the coefficient of the lagged error term than the previous one. However, this procedure requires the use of a first order autoregressive [AR(1)] term, which in turn may be correlated with the lagged dependent variable. Therefore, the model may suffer from the simultaneity problem that was described above. In this case the seemingly unrelated regression procedure may produce inefficient estimates and an alternative technique needs to be used.

Two Stage Least Squares: This procedure is commonly used in estimating models with endogenous variables on the right hand side of the equations because it corrects for the simultaneity problem. The Two Stage Least Squares (TSLS) technique, as the name indicates, consists of two stages. In the first, the dependent variables on all the exogenous variables in the model are regressed using the ordinary least squares technique to obtain an instrumental variable that is uncorrelated with the errors. In the second stage, the 
instrumental variable in the original equation is used instead of the actual variable and the ordinary least squares technique is performed. The basic idea of the TSLS technique is to purify the explanatory variables of the effects of the errors to produce consistent estimates (Gujarati, 1995). Because the TSLS technique produces consistent estimates while the other two don't because of the problem of autocorrelation in the errors, it is used in this study as the tool to estimate the eight supply and demand equations.

In addition, all regressions were tested for the problem of serial correlation (in the errors), which is common in time-series regressions. The tool usually used to detect the presence of this problem is the Durbin-Watson statistic developed by Durbin and Watson (1951). However, since a lagged dependent variable was used in all of the regressions, the Durbin-Watson Statistic becomes inappropriate because it is biased toward showing no serial correlation even if the errors are correlated (Gujarati, 1995; Pindyck and Rubinfeld, 1991). Alternatively, another test is used known as Durbin-h, which was developed by Durbin (1970). The Durbin-h test has the advantage of not being affected by either the number of explanatory variables or lagged variables. Durbin-h, however, has two shortcomings. First, it cannot be used if the denominator is negative because we cannot take the square root of a negative number, a problem which occurs if the product of the variance of the lagged variable and the number of observations is greater than one. Second, it detects only first order serial correlation.

An alternative test for serial correlation is the Lagrange Multiplier (LM) test known also as the Breusch-Godfrey test developed by Godfrey (1978) and Breusch (1978). Unlike the Durbin-Watson statistic for AR(1) errors, the LM test may be used to test for higher order AR errors, and is applicable whether or not there are lagged 
dependent variables. Therefore, it is recommended whenever there is concern with the possibility that errors exhibit autocorrelation. The null hypothesis of the LM test is that there is no serial correlation up to lag order $\mathrm{p}$. The LM test is performed in two steps. First, the regression equation is estimated using OLS and the errors are obtained. Second, the errors on all the regressors in the original equation plus the lagged values of the errors up to the $\mathrm{p}$ lag are regressed.

The criteria used to detect the presence of serial correlation are the t-statistics of the lagged errors and the $\left(n-p^{*} R^{2}\right)$ of the Breusch-Godfrey LM test statistic. This LM statistic is computed as the number of observations minus the residual lags times the Rsquared obtained from second step regression. Under quite general conditions, the LM test statistic is asymptotically distributed as a Chi-Square test: $\chi^{2}(\mathrm{p})$. Fortunately, the EVIEWS software that is used in this study reports the LM test statistic and the probability of rejecting the null hypothesis. In the next subsections the probability of the LM test is reported with each regression and abbreviated as: LM-p. Any LM-p higher than 0.05 indicates that the null hypothesis (i.e. no serial correlation) cannot be rejected at $5 \%$ or lower levels of significance. Tests is based on two lags of the errors.

All notations are the same as those used in chapter three. A summary of the results is provided in table (26) in Appendix (7). The equations were estimated in loglinear forms, which means that the estimated coefficients can be interpreted as elasticities. Note, numbers in parentheses below any regression are the t-statistics. 


\section{(4.2.1) PRODUCTION}

Below are the estimation results for the two production functions. First, good (X):

$$
\begin{aligned}
& \mathrm{QX}_{\mathrm{X}}=-11.2-1.8 \mathrm{P}_{\mathrm{Y}}+1.1 \mathrm{P}_{\mathrm{X}}+0.8 \mathrm{~L}+0.3 \mathrm{~K}+0.9 \mathrm{EX}_{\mathrm{OIL}}+0.02 \mathrm{Q}_{\mathrm{X}}(\mathrm{t}-1)
\end{aligned}
$$

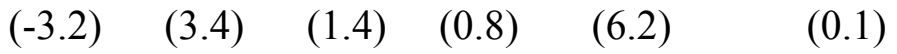

$$
\begin{aligned}
& \overline{\mathrm{R}}^{2}=0.84 \quad \mathrm{LM}-\mathrm{p}=0.4
\end{aligned}
$$

The estimated equation shows that the coefficients of prices are statistically significant with the correct signs. The coefficient of $\left(\mathrm{P}_{\mathrm{X}}\right)$ suggests that an increase in $\left(\mathrm{P}_{\mathrm{X}}\right)$ by one percent increases $\left(\mathrm{Q}_{\mathrm{X}}\right)$ by 1.1 percent, while the coefficient of $\left(\mathrm{P}_{\mathrm{Y}}\right)$ suggests that an increase in the price of good $(\mathrm{Y})$ by one percent decreases $\left(\mathrm{Q}_{\mathrm{X}}\right)$ by 1.8 percent. The coefficients of the factor endowments are both positive but statistically insignificant suggesting that $\left(\mathrm{Q}_{\mathrm{x}}\right)$ is unresponsive to changes in $(\mathrm{L})$ and $(\mathrm{K})$. The coefficient of oil exports $\left(\mathrm{EX}_{\mathrm{OIL}}\right)$ is positive and highly significant, implying that an increase in $\left(\mathrm{EX}_{\mathrm{OIL}}\right)$ by one percent increases $\left(\mathrm{Q}_{\mathrm{x}}\right)$ by 0.9 percent. This result is consistent with the fact that the chemical industry is dependent on the oil industry and is affected by the same factors that affect the latter. Finally, coefficient of the lagged $\left(\mathrm{Q}_{\mathrm{x}}\right)$ is positive but statistically insignificant, suggesting that past levels of production do not influence the current level. This is consistent with the fact that the chemical industry is export-oriented, making it vulnerable to changes in world prices, supply, and demand.

Next, the results of estimating (QY) are presented:

$$
\begin{aligned}
& \mathrm{Q}_{\mathrm{Y}}=3.1+0.2 \mathrm{P}_{\mathrm{Y}}+0.2 \mathrm{P}_{\mathrm{X}}-0.4 \mathrm{~L}+0.6 \mathrm{~K}+0.2 \mathrm{EX}_{\mathrm{OIL}}+0.1 \mathrm{Q}_{\mathrm{Y}}(\mathrm{t}-1) \\
& \begin{array}{llll}
(0.8) \quad(1.5) \quad(-1.2) \quad(3.3) \quad(2.8) \quad(1.0)
\end{array} \\
& \overline{\mathrm{R}}^{2}=0.93 \quad \mathrm{LM}-\mathrm{p}=0.57
\end{aligned}
$$


The estimated equation shows that $\left(\mathrm{P}_{\mathrm{Y}}\right)$ has the right sign but $\left(\mathrm{P}_{\mathrm{X}}\right)$ does not. The coefficients of prices are both statistically insignificant. The coefficient of the labor force (L) is negative and statistically insignificant. The coefficient of the capital endowment is positive and highly significant, suggesting that an increase in $(K)$ by one percent increases $\left(\mathrm{Q}_{\mathrm{Y}}\right)$ by 0.6 percent. This means that $\left(\mathrm{Q}_{\mathrm{Y}}\right)$ benefits from the abundance of capital in the economy. This result contradicts the expectation that $(\mathrm{K})$ has a negative sign, which was derived from the comparative statics in chapter three and was based on Rybcznski's Theorem. The coefficient of oil exports $\left(\mathrm{EX}_{\mathrm{OIL}}\right)$ is positive and statistically significant, implying that an increase in $\left(\mathrm{EX}_{\mathrm{OIL}}\right)$ by one percent increases $\left(\mathrm{Q}_{\mathrm{Y}}\right)$ by 0.2 percent. Finally, the coefficient of the lagged $\left(\mathrm{Q}_{\mathrm{Y}}\right)$ is positive but statistically insignificant

\section{(4.2.2) CONSUMPTION}

Below are the estimation results for the two consumption functions. First, the consumption function of good $(\mathrm{X})$ :

$$
\begin{aligned}
& \mathrm{C}_{\mathrm{X}}=17.3-1.4 \mathrm{P}_{\mathrm{Y}}+2.9 \mathrm{P}_{\mathrm{X}}-4.9 \mathrm{~L}+2.9 \mathrm{~K}-0.9 \mathrm{~T}+0.01 \mathrm{C}_{\mathrm{X}}(\mathrm{t}-1)
\end{aligned}
$$

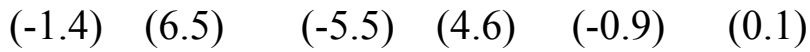

$$
\begin{aligned}
& \overline{\mathrm{R}}^{2}=0.78 \quad \mathrm{LM}-\mathrm{p}=0.97
\end{aligned}
$$

The consumption equation shows that $\left(\mathrm{P}_{\mathrm{X}}\right)$ has the wrong sign, which is positive and highly significant. This result is not surprising since $\left(\mathrm{P}_{\mathrm{X}}\right)$ is highly correlated with the price of oil, therefore an increase in the price of oil increases the national income, which makes consumers able to afford more expensive goods (i.e. higher $\left(\mathrm{P}_{\mathrm{X}}\right)$ ). The price of good $(\mathrm{Y})$ is statistically insignificant. The negativity $\left(\mathrm{P}_{\mathrm{Y}}\right)$ shows that the income effect exceeds the substitution effect (this will be discussed in more detail in chapter five). Labor force (L) has the wrong sign, negative, and is statistically significant, implying that 
an increase in the labor force by one percent reduces the demand for good $(\mathrm{Y})$ by five percent. Capital endowment (K) has the right sign, positive, and statistically significant, implying that an increase in capital endowment by one percent increases demand by about three percent. Note that $(\mathrm{K})$ can be viewed as a measure of income because interest on capital is one source of income to the household, thus the higher the capital stock a country accumulates the more it is able to consume. The coefficient of government transfers $(\mathrm{T})$ to households is negative but statistically insignificant. Finally, the lagged value of $\left(C_{X}\right)$ is positive but statistically insignificant.

Next, the consumption function of $\operatorname{good}(\mathrm{Y})$ :

$$
\begin{aligned}
& \mathrm{C}_{\mathrm{Y}}=-2.0-1.0 \mathrm{P}_{\mathrm{Y}}+0.7 \mathrm{P}_{\mathrm{X}}-0.8 \mathrm{~L}+0.9 \mathrm{~K}+1.0 \mathrm{~T}+0.5 \mathrm{C}_{\mathrm{Y}}(\mathrm{t}-1) \\
& \begin{array}{lllll}
(-1.6) \quad(3.1) \quad(-2.4) \quad(3.8) \quad(2.3) \quad(3.1)
\end{array} \\
& \overline{\mathrm{R}}^{2}=0.83 \quad \mathrm{LM}-\mathrm{p}=0.23
\end{aligned}
$$

The consumption equation for good $(\mathrm{Y})$ shows that prices $\left(\mathrm{P}_{\mathrm{Y}}\right.$ and $\left.\mathrm{P}_{\mathrm{X}}\right)$ have the expected signs but only $\left(\mathrm{P}_{\mathrm{X}}\right)$ is statistically significant. This result is not surprising given the fact that good $(\mathrm{Y})$ is in excess demand making consumers less sensitive to changes in its price. Factor endowments (L and $\mathrm{K}$ ) are both statistically significant. However, labor endowment has the wrong sign, negative, as in the $\left(C_{X}\right)$ equation, implying an increase in (L) by one percent reduces consumption by 0.8 percent. On the other hand, the coefficient of capital endowment has the right sign, positive, implying that an increase in (K) by one percent increases the demand for good (Y) by about one percent. As with $\left(\mathrm{C}_{\mathrm{X}}\right)$, capital endowment can be viewed as a proxy for income since it represents one source of income to the household as explained in chapter three (subsection 3.1.2). The coefficient of government transfers $(\mathrm{T})$ is positive and statistically significant, implying 
that an increase in $(\mathrm{T})$ by one percent increases $\left(\mathrm{C}_{\mathrm{Y}}\right)$ by about one percent. Finally, the lagged value of $\left(\mathrm{C}_{\mathrm{Y}}\right)$ is positive and statistically significant implying that an increase in last year's consumption by one percent increases current consumption by 0.5 percent.

\section{(4.2.3) DEMAND FOR CAPITAL}

This subsection analyzes the results of the demand for capital equations. First, for $\operatorname{good}(\mathrm{X})$ :

$$
\begin{aligned}
& \mathrm{K}_{\mathrm{X}}=5.9-0.04 \mathrm{P}_{\mathrm{Y}}-0.1 \mathrm{P}_{\mathrm{X}}-0.5 \mathrm{~L}+1.1 \mathrm{~K}-0.1 \mathrm{EX}_{\mathrm{OIL}}+0.5 \mathrm{~K}_{\mathrm{X}}(\mathrm{t}-1) \\
& \begin{array}{llllll}
(-0.1) & (-0.5) & (-1.4) & (5.2) & (-1.9)
\end{array} \\
& \mathrm{R}^{2}=0.95 \quad \text { LM-p }=0.51
\end{aligned}
$$

The estimated equation for the demand for capital in the production of good (X) does not depend on the prices of goods ( $\mathrm{X}$ and $\mathrm{Y}$ ), both are statistically insignificant. Demand for capital $\left(\mathrm{K}_{\mathrm{X}}\right)$ is sensitive to changes in the endowment of capital, which has the right sign, positive, and statistically significant. It implies that an increase in $(\mathrm{K})$ by one percent increases $\left(\mathrm{K}_{\mathrm{X}}\right)$ by 1.1 percent. This is consistent with the fact that the production of good $(\mathrm{X})$ is capital intensive, making it benefit from the abundance of capital in the economy. The coefficient of (L) has the right sign, negative, but statistically insignificant. The negativity of (L) is consistent with the Rybcznski's Theorem. The coefficient of oil exports ( $\mathrm{EX}_{\mathrm{OIL}}$ ) is negative and statistically significant (at $10 \%$ level of significance), implying that an increase in oil exports by one percent reduces the demand for capital in the $(\mathrm{X})$ industry by 0.1 percent. Finally, the lagged level of $\left(\mathrm{K}_{\mathrm{X}}\right)$ is highly significant and positive, suggesting that an increase in $\left(\mathrm{K}_{\mathrm{X}}\right)$ by one percent increases the demand in the current year by 0.5 percent.

Next, demand for capital for good (Y): 


$$
\begin{aligned}
& \mathrm{K}_{\mathrm{Y}}=3.4+0.4 \mathrm{P}_{\mathrm{Y}}-0.4 \mathrm{P}_{\mathrm{X}}-0.1 \mathrm{~L}+0.5 \mathrm{~K}+0.1 \mathrm{EX}_{\mathrm{OIL}}+0.6 \mathrm{~K}_{\mathrm{Y}}(\mathrm{t}-1) \\
& \begin{array}{lllll}
(1.1) \quad(-2.5) & (-0.2) & (2.1) & (0.8)
\end{array} \\
& \mathrm{R}^{2}=0.92 \quad \mathrm{LM}-\mathrm{p}=0.45
\end{aligned}
$$

The estimated function for the demand for capital in the production of good (Y) does not depend on the price of good (Y), which is statistically insignificant. However, the price of good $(\mathrm{X})$ has the right sign, negative, and is statistically significant, implying that an increase in $\left(\mathrm{P}_{\mathrm{X}}\right)$ by one percent reduces the demand for capital $\left(\mathrm{K}_{\mathrm{Y}}\right)$ by $0.4 \%$. This result is consistent with the Samuelson-Stopler Theorem. In addition, the (Y) industry's demand for capital is negatively affected by the demand for capital in the (X) industry (which depends positively on the price of good $(\mathrm{X})$ ) because the stock of capital in the economy is assumed to be fixed in the short run. The factors of production ( $\mathrm{L}$ and $\mathrm{K}$ ) have the unexpected signs but only $(\mathrm{K})$ is statistically significant, implying that an increase in $(\mathrm{K})$ by one percent increases the demand for capital $\left(\mathrm{K}_{\mathrm{Y}}\right)$ by 0.5 percent. This shows that sector (Y) benefits from the abundance of capital in the economy. Exports of oil have a positive but statistically insignificant coefficient. Finally, the lagged level of demand for capital is positive and statistically significant, implying that an increase in previous demand by one percent increases the demand in the current period by 0.6 percent.

\section{(4.2.4) DEMAND FOR LABOR}

This subsection presents the results of estimating the demand for labor equations.

First, demand for capital for good $(\mathrm{X})$ :

$$
\begin{aligned}
& \mathrm{L}_{\mathrm{X}}=-0.7-0.02 \mathrm{P}_{\mathrm{Y}}+0.3 \mathrm{P}_{\mathrm{X}}-0.3 \mathrm{~L}+0.4 \mathrm{~K}+0.03 \mathrm{EX}_{\mathrm{OIL}}+0.7 \mathrm{~L}_{\mathrm{X}}(\mathrm{t}-1)
\end{aligned}
$$

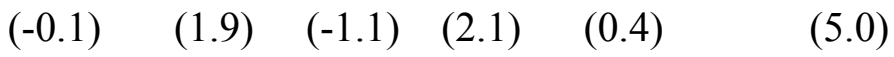

$$
\begin{aligned}
& \overline{\mathrm{R}}^{2}=0.94 \quad \mathrm{LM}-\mathrm{p}=0.54
\end{aligned}
$$


The coefficient of $\left(\mathrm{P}_{\mathrm{Y}}\right)$ has the right sign, negative, but statistically insignificant, while the coefficient of $\left(\mathrm{P}_{\mathrm{X}}\right)$ has the right sign, positive, and statistically significant (at $10 \%$ level of significance). The latter implies that an increase in $\left(\mathrm{P}_{\mathrm{X}}\right)$ by one percent increases the demand for labor by 0.02 percent. This result is consistent with the Samuelson-Stopler Theorem. Labor endowment has the right sign, negative, but statistically insignificant. Capital endowment's coefficient has the right sign, positive, and statistically significant, implying that an increase in $(\mathrm{K})$ by one percent increases the demand for labor $\left(\mathrm{L}_{\mathrm{X}}\right)$ by 0.4 percent. This result is consistent with the Rybcznski's Theorem. The coefficient of oil exports (EX $\mathrm{EIL}_{\text {) }}$ is positive but statistically insignificant. Finally, the lagged value of $\left(L_{X}\right)$ is positive and highly statistically significant, implying that an increase in last year's demand for labor by one percent increases the demand in the current year by 0.7 percent.

Next, demand for labor for good (Y):

$$
\begin{aligned}
& \mathrm{L}_{\mathrm{Y}}=-0.4+0.3 \mathrm{P}_{\mathrm{Y}}-0.01 \mathrm{P}_{\mathrm{X}}+0.04 \mathrm{~L}+0.1 \mathrm{~K}+0.04 \mathrm{EX}_{\mathrm{OIL}}+0.6 \mathrm{Ly}(\mathrm{t}-1) \\
& \begin{array}{lllll}
(1.1) & (-0.1) \quad(0.1) & (0.9) \quad(0.8) & (2.8)
\end{array} \\
& \mathrm{R}^{2}=0.90 \quad \mathrm{LM}-\mathrm{p}=0.42
\end{aligned}
$$

The coefficients of prices of goods ( $\mathrm{X}$ and $\mathrm{Y}$ ) are statistically insignificant. Factor endowments are statistically insignificant. The coefficient of oil exports is positive but statistically insignificant. Finally, the lagged level of $\left(\mathrm{L}_{\mathrm{Y}}\right)$ is positive and statistically significant, implying that an increase in last year's demand by one percent increases current year's demand by 0.6 percent.

\section{Comments}

Before concluding the estimation section, it is noteworthy to comment on two issues. First, the robustness of the results obtained from the current specification of the model. 
Specifically, we want to know how would the results change if two of the explanatory variables were omitted, namely, government transfers and oil revenues. In an earlier version of the model, these two variables were not specified, however they were included in the current model. The results of the earlier version of the model are summarized in table (27) in Appendix (8). The results show that among the forty coefficients estimated, only three have changed signs. This shows that the estimated coefficients are, relatively, robust and insensitive to model specification.

Second, as it was mentioned earlier in this section, the coefficients of the labor force in some of the estimated equations have the wrong signs and statistically significant as in the consumption equations. These results indicate that there are other factors affecting the relationship between consumption and the labor force that are not fully captured by the model. One explanation may be related to the unusual structure of the labor force in Kuwait. Kuwait is highly dependent on foreign workers who have two characteristics. First, they work on the basis of limited time contracts and are not granted permanent residency or citizenship. This discourages them from consuming or investing their earnings in Kuwait because they know that they have to leave as soon as their contracts expire. Therefore, they transfer most of their earnings to their home countries. For example, in 1999 foreign employees transferred KD 400 million or 9.1\% of non-oil GDP. Second, a significant portion of foreign labor work at low pay jobs, which gives them a low purchasing power and as a result lowers consumption. In sum, the characters of the labor market and the immigration policies in Kuwait may explain the negativity of the labor force coefficients in the consumption equations in particular and other equations in 
general. A more ambitious research may look at the labor market at a more disaggregated level.

\section{(4.3) WELFARE LOSS}

This section estimates the welfare loss from the current tariff regime in Kuwait. The tool that is used in the estimation is the Equivalent Variation (EV) measure of welfare loss (equation (13')) that was derived in section (3.3.2). The EV, as a percentage of GDP was defined as follows:

$\mathrm{EV} / \mathrm{GDP}=-0.5 \mathrm{r}^{2} \eta^{\mathrm{C}} \alpha$

Where $\mathrm{r}=\left(\mathrm{P}-\mathrm{P}^{*}\right) / \mathrm{P}=\mathrm{t} / \mathrm{P}, \eta^{\mathrm{C}}=\left(\partial \mathrm{IM}^{\mathrm{C}} / \partial \mathrm{P}\right) \mathrm{P} / \mathrm{IM}^{\mathrm{C}}$, and $\alpha=\mathrm{P}^{*} \mathrm{IM}^{\mathrm{C}} / \mathrm{GDP}$.

The first term in the EV is $\left(\mathrm{r}^{2}\right)$, which is the square of the tariff rate. This term was calculated under the current tariff rate of $4 \%$. Thus, $r$ is:

$\mathrm{r}=(1.04-1) / 1.04=0.038$

and

$\mathrm{r}^{2}=0.0015$

The second term is the compensated price elasticity of imports $\left(\eta^{C}\right)$. As stated in section (3.7.1), this term is empirically estimated by regressing imports on import prices and GDP. However, a great debate exists about the accuracy of estimates of import elasticity. They are accused of being biased downward (Orcutt, 1950) or upward (Magee, 1975). Empirical estimates vary by countries and estimation techniques. Below, some estimates from the literature are presented for developed countries : Houthakker and Magee (1969): (-0.13 and -1.66), Cline et al (1978): (-0.61 and -1.94), De Melo and Tarr (1990): (-1.8 and -3.9) and Floyd (1965): (-1.5 and - 2.7). However, developing countries, with higher dependency on imports, have elasticities less than those of 
developed countries. In the case of Kuwait, no estimates of manufactured imports exist; and only one study (Khoja and Sadler (1979)) has estimated the elasticity for demand for total imports to be (-1.83). In the current study, the import price elasticity won't be estimated, because of the controversy surrounding its estimation, but it is assigned two values. One value is $(-0.5)$, corresponding to an inelastic demand for imports, and another value (-1.5), corresponding to an elastic demand for imports. These are short-term elasticities.

The last term in the EV equation is $(\alpha)$, defined as the ratio of nominal imports (of good Y only) to GDP. It was calculated straightforwardly by dividing (P*IM) by (GDP) for each year. $(\alpha)$ ranges between $(0.05$ and 0.25$)$ with a mean $(0.14)$.

In addition to calculating EV as a percentage of GDP, it can be calculated in terms of money (millions of KDs). Thus, the relevant EV becomes:

$\mathrm{EV}=-0.5 \mathrm{r}^{2} \eta^{\mathrm{C}} \mathrm{P}^{*} \mathrm{IM}$

The next two subsections will discuss the results of estimating the EV under the two measures.

\section{(4.3.1) EV in Money Metric}

In equation (1), all the terms on the right hand side are constants except for $(\alpha)$, which changes over time depending on the ratio of nominal imports to GDP. Table (8) presents the results of estimating equation (1) for the sample period (1969-1999). For the case of $\left(\eta^{C}\right)=-0.5$ the results show that the EV is between ( KD -0.033 million) and (KD -0.33 million) with a mean (KD -0.2 million). For the case of $\left(\eta^{C}\right)=-1.5$ the results are three times those of the former case, the EV is between ( KD -0.1 million) and (KD - 
million) with a mean (KD -0.6 million). These welfare losses are relatively low compared to the magnitude of GDP, which averaged (KD 5052 millions) during the

\begin{tabular}{llllll}
\hline YEAR & \multicolumn{2}{c}{ EV } & YEAR & \multicolumn{2}{c}{ EV } \\
& $\eta^{\mathrm{C}}=-0.5$ & $\eta^{\mathrm{C}}=-1.5$ & & $\eta^{\mathrm{C}}=-0.5$ & $\eta^{\mathrm{C}}=-1.5$ \\
& & & & & \\
\hline 1969 & -0.03 & -0.09 & 1985 & -0.2 & -0.6 \\
1970 & -0.03 & -0.09 & 1986 & -0.2 & -0.6 \\
1971 & -0.03 & -0.09 & 1987 & -0.2 & -0.6 \\
1972 & -0.04 & -0.1 & 1988 & -0.3 & -0.9 \\
1973 & -0.04 & -0.1 & 1989 & -0.3 & -0.9 \\
1974 & -0.07 & -0.2 & 1990 & -0.3 & -0.9 \\
1975 & -0.08 & -0.2 & 1991 & -0.3 & -0.9 \\
1976 & -0.1 & -0.4 & 1992 & -0.3 & -0.9 \\
1977 & -0.2 & -0.6 & 1993 & -0.3 & -0.9 \\
1978 & -0.2 & -0.6 & 1994 & -0.3 & -0.9 \\
1979 & -0.2 & -0.6 & 1995 & -0.3 & -0.9 \\
1980 & -0.3 & -0.9 & 1996 & -0.3 & -0.9 \\
1981 & -0.3 & -0.9 & 1997 & -0.3 & -0.9 \\
1982 & -0.3 & -0.9 & 1998 & -0.3 & -0.9 \\
1983 & -0.3 & -0.9 & 1999 & -0.3 & -0.9 \\
1984 & -0.3 & -0.9 & & & \\
\hline
\end{tabular}

Table (8): EV (million KDs)

sample period. There are two sources for the low welfare losses. First, the elasticity of imports is relatively low compared to those of developed countries, which are generally close to two. In addition, these estimates are for the short-term, however the long-term elasticities are much greater. Second, the low tariff rate contributes the most to the low welfare loss. To see the difference between the current tariff rate in Kuwait (4\%) and the average rate in developing countries (19.6\%), the EV was re-estimated under the latter rate. The average welfare loss, with $\left(\eta^{C}=-1.5\right)$, has increased sharply from (KD -0.6 million) to (KD -11.7 million). 


\section{(4.3.2) EV AS PERCENTAGE OF GDP}

This subsection estimates the welfare loss (EV) as a percentage of GDP using equation (2). The results are presented in table (9). The table shows that the welfare loss is very small as a percentage of GDP. For the case where $\left(\eta^{\mathrm{C}}=-0.5\right)$ the EV ranged between $(-0.002 \%$ and $-0.009 \%)$ with an average of $(-0.005 \%)$. For the case where $\left(\eta^{\mathrm{C}}=\right.$ $-1.5)$ the EV ranged between $(-0.006 \%$ and $-0.03 \%)$ with an average of $(-0.015 \%)$. As stated in the previous subsection, these low welfare effects are attributed to the low import elasticity and the low tariff rate. As in the previous subsection, the EV/GDP was re-estimated under the average tariff rate in developing countries $(19.6 \%)$, and it was found that the average welfare loss, with $\left(\eta^{\mathrm{C}}=-1.5\right)$, has increased sharply from ($0.015 \%)$ to $(-0.3 \%)$.

\begin{tabular}{llllll}
\hline YEAR & \multicolumn{2}{c}{ EV } & YEAR & \multicolumn{2}{c}{$E V$} \\
& $\eta^{\mathrm{C}}=-0.5$ & $\eta^{\mathrm{C}}=-1.5$ & & $\eta^{\mathrm{C}}=-0.5$ & $\eta^{\mathrm{C}}=-1.5$ \\
\hline & & & & & \\
1969 & -0.002 & -0.006 & 1985 & -0.005 & -0.015 \\
1970 & -0.002 & -0.006 & 1986 & -0.005 & -0.015 \\
1971 & -0.002 & -0.006 & 1987 & -0.004 & -0.016 \\
1972 & -0.002 & -0.006 & 1989 & -0.005 & -0.015 \\
1973 & -0.002 & -0.006 & 1990 & -0.005 & -0.015 \\
1974 & -0.003 & -0.009 & 1991 & -0.007 & -0.021 \\
1975 & -0.003 & -0.009 & 1992 & -0.007 & -0.027 \\
1976 & -0.005 & -0.015 & 1993 & -0.006 & -0.021 \\
1977 & -0.006 & -0.018 & 1994 & -0.005 & -0.018 \\
1978 & -0.006 & -0.018 & 1995 & -0.006 & -0.015 \\
1979 & -0.005 & -0.015 & 1996 & -0.006 & -0.018 \\
1980 & -0.006 & -0.018 & 1997 & -0.006 & -0.018 \\
1981 & -0.006 & -0.018 & 1998 & -0.006 & -0.018 \\
1982 & -0.006 & -0.018 & 1999 & -0.005 & -0.015 \\
1983 & -0.007 & -0.021 & & & \\
1984 & -0.007 & -0.021 & & & \\
\hline
\end{tabular}

Table (9): EV as percentage of GDP 


\section{CHAPTER (5)}

\section{SIMULATION}

\section{INTRODUCTION}

This chapter is divided into four main sections. Each section is in turn divided into three subsections. Each subsection analyzes the effects of a given WTO agreement on demand and supply equations, balance of trade and welfare, respectively. First, section (5.1) analyzes the effects of reducing import tariff rates by $25 \%$. Second, section (5.2) analyzes the effects of an increase in the world's price of the importable good by $10 \%$. Third, section (5.3) analyzes the effects of a $10 \%$ reduction in the world's price of the importable good. Finally, section (5.4) analyzes the effects of reducing government purchases of domestic output by $50 \%$ as a result of enforcing the agreement on government procurements. 


\section{(5.1) TARIFF REDUCTION AGREEMENT}

Under the WTO agreement of tariff reduction, industrialized countries are required to reduce their import tariffs by $36 \%$ over a ten year period, compared to a $25 \%$ reduction over fifteen years by developing countries. However, many countries reduced their tariffs immediately after the conclusion of the Uruguay round in 1994. For example, developing countries have reduced their tariffs, on average, by $25 \%$. This study hypothesizes the case of a 25\% reduction in tariffs by Kuwait for the period 1995-99.

\section{(5.1.1) EFFECTS ON SUPPLY AND DEMAND}

The effects of the tariff reduction on supply and demand were calculated using simulation procedure utilizing the parameters estimated in chapter four (section 4.1). In the simulation exercise, domestic prices were specified under a $3 \%$ tariff rate for the 1995-99 period and a 4\% rate for the period 1969-94. The effects of this agreement were calculated as the difference between the simulated values under the current tariff rate and the simulated values under the new rate. The effects on supply and demand for the period 1995-99 are presented in table (10).

The results show that the reduction in tariffs, as expected, has a minor effect on supply and demand since it corresponds to only about $1 \%$ decline in price. Consumption $\left(\mathrm{C}_{\mathrm{Y}}\right)$ increased for the period $1995-9$ by (KD 53 million) or $(0.9 \%)$, while production $\left(\mathrm{Q}_{\mathrm{Y}}\right)$ declined by (KD 4 million) or $(0.15 \%)$. The rise in $\left(\mathrm{C}_{\mathrm{Y}}\right)$ and the decline in $\left(\mathrm{Q}_{\mathrm{Y}}\right)$ in response to the decline in price are consistent with the laws of demand and supply which dictate negative and positive relationships between price and quantity, respectively. Demand for labor $\left(\mathrm{L}_{\mathrm{Y}}\right)$ has declined slightly by (730 employees) or $(0.27 \%)$ and demand 
for capital $\left(\mathrm{K}_{\mathrm{Y}}\right)$ declined by (KD 3.4 million) or $(0.34 \%)$. Both effects are in the same direction of the decline in output $\left(\mathrm{Q}_{\mathrm{Y}}\right)$, but demand for capital is more elastic than demand for labor. The relatively lower decline in $\left(\mathrm{L}_{Y}\right)$ can be attributed to institutional restrictions that prevent firms from laying off employees in the case of a decline in production. Such restrictions may include skill specificity and long term labor contracts.

All numbers in millions of KDs except $\mathrm{L}_{X}$ and $\mathrm{L}_{Y}$ in thousands of employees

\begin{tabular}{lcccccccc}
\hline YEAR & $\mathrm{C}_{\mathrm{Y}}$ & $\mathrm{Q}_{\mathrm{Y}}$ & $\mathrm{L}_{\mathrm{Y}}$ & $\mathrm{K}_{\mathrm{Y}}$ & $\mathrm{C}_{\mathrm{X}}$ & $\mathrm{Q}_{\mathrm{X}}$ & $\mathrm{L}_{\mathrm{X}}$ & $\mathrm{K}_{\mathrm{X}}$ \\
\hline 1995 & 10.4 & -1.1 & -0.1 & -0.6 & 0.4 & 2.0 & 0.00 & 0.1 \\
1996 & 10.8 & -1.0 & -0.1 & -0.6 & 0.5 & 2.0 & 0.00 & 0.1 \\
1997 & 11.3 & -1.1 & -0.1 & -0.7 & 0.4 & 1.9 & 0.00 & 0.1 \\
1998 & 11.1 & -1.1 & -0.2 & -0.7 & 0.2 & 3.3 & 0.00 & 0.1 \\
1999 & 19.6 & -0.9 & -0.2 & -0.7 & 0.3 & 3.2 & 0.00 & 1.0 \\
TOTAL & & & & & & & & \\
Million KDs & 53.1 & -4.2 & -0.73 & -3.4 & 1.9 & 12.4 & 0.00 & 0.45 \\
Percent (\%) & 0.9 & -0.15 & -0.27 & -0.34 & 1.37 & 0.5 & 0.02 & 0.03 \\
\hline
\end{tabular}

Table (10): Effect on Supply and Demand

The effects on the sector producing good (X) are generally smaller than those of sector $(\mathrm{Y})$. The demand for capital $\left(\mathrm{K}_{\mathrm{X}}\right)$ increased by (KD 0.4 million) or $(0.03 \%)$. This increase is clearly much smaller than the decline in the demand for capital in sector $(\mathrm{Y})$, which means that there will be excess supply of capital in the economy. Supply ( $\left.Q_{x}\right)$ increased by (KD 12.4 million) or $(0.5 \%)$. Demand for labor $\left(\mathrm{L}_{\mathrm{X}}\right)$ increased slightly by $(0.02 \%)$, which is less than the decline in $\left(\mathrm{L}_{\mathrm{Y}}\right)$, this mean that there will be excess supply of labor in the economy. Finally, the demand $\left(\mathrm{C}_{\mathrm{X}}\right)$ has increased by (KD 1.9 million) or (1.4\%). Theoretically, the effect on the consumption of $(\mathrm{X})$ depends on the relative magnitudes of the income and substitution effects and on which one will dominate the other. The decline in the price of good (Y), which accounts for about $96 \%$ of the total 
expenditure by the household, has a positive income effect because it increases the household's income. By contrast, the decline in the price of good (Y) makes good (X) relatively more expensive, therefore consumption of good (X) has to decrease. Empirically, the increase in $\left(C_{X}\right)$ implies that the income effect dominates the substitution effect. That is, consumers are richer as a result of the decline in the price of good $(\mathrm{Y})$.

\section{(5.1.2) EFFECTS ON BALANCE OF TRADE}

This subsection analyzes the effects of the tariff reduction agreement on the balance of trade. Exports and imports are calculated as the difference between consumption and production in each sector (see subsection 3.1.4 for details). Simulation results are presented below in table (11). First, imports of good $\mathrm{Y}\left(\mathrm{IM}_{\mathrm{Y}}\right)$ have increased by (KD 58.3 million) or $(1.4 \%)$ because production $\left(\mathrm{Q}_{\mathrm{Y}}\right)$ has declined, while consumption $\left(\mathrm{C}_{\mathrm{Y}}\right)$ has increased. This increased the excess demand in the economy, as a result imports had to increase. Second, exports $\left(\mathrm{EX}_{\mathrm{X}}\right)$ have increased by (KD 10.5 million) or $(1.9 \%)$ because production $\left(\mathrm{Q}_{\mathrm{x}}\right)$ has increased by more than the increase in consumption $\left(\mathrm{C}_{\mathrm{X}}\right)$. As a result, the excess supply of good $(\mathrm{X})$ in the domestic market has increased, therefore exports increased. Finally, the balance of trade (TB) has declined by (KD 47.8 million) as a result of the higher increase in imports than the increase in exports. This result is expected from the point of view of international trade theory. The reason is that import tariffs protect the industry producing the importable good from international competition by making foreign made goods more expensive. This induces domestic producers to divert economic resources to the protected industry, away from the exportable good industry. However, a reduction in protection (i.e. cuts in tariffs) makes 
the importable sector less profitable and, therefore, economic resources move back to the exportable good sector. As a result, output contracts in the importable sector and imports have to increase to fill the gap in excess demand. On the other hand, output and exports in the exportable sector increases as well. This result is consistent with Lerner's Theorem which states that import tariffs have a similar effect to export taxes, therefore a reduction in tariffs should increase imports and exports.

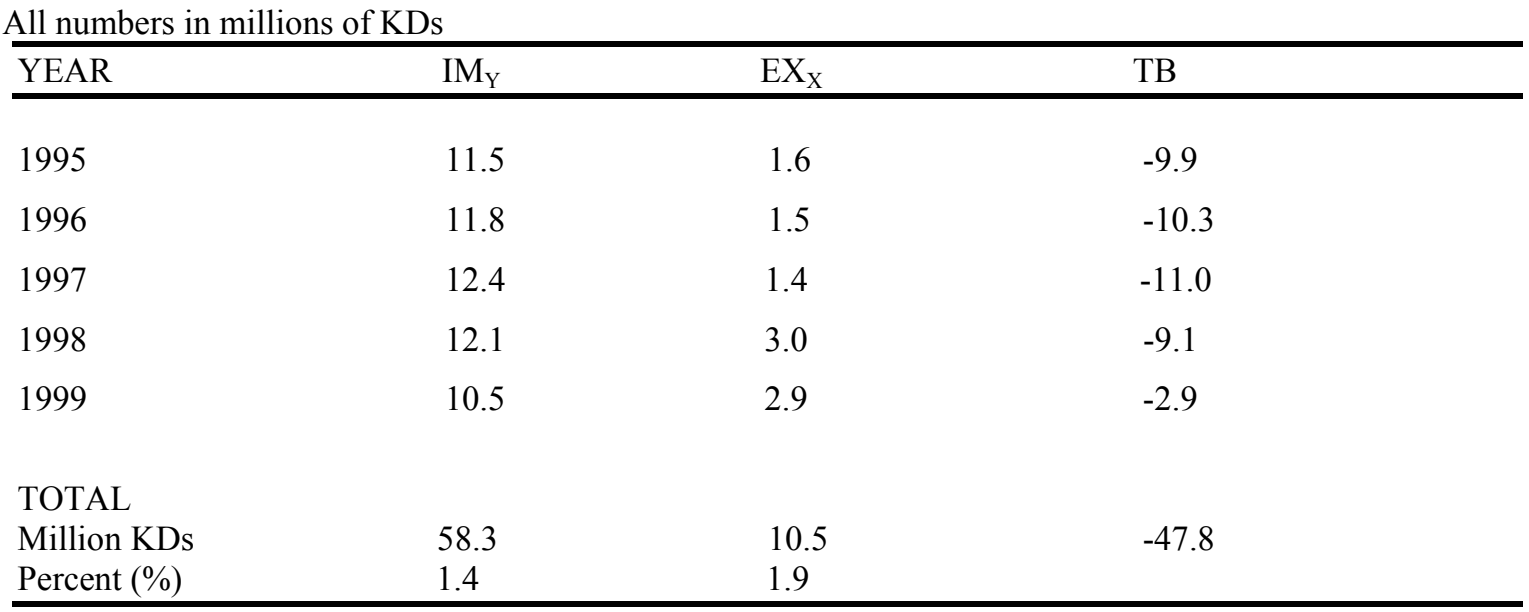

Table (11): Effect on Trade Balance 


\section{(5.1.3) EFFECTS ON WELFARE}

In this subsection, the effects of the tariff cut on welfare are measured and analyzed. The tool that is used is the compensating change in utility measure that was derived in section (3.3.1). This measure is estimated both in millions of KDs (equation 7):

$$
E_{u} d u=-\operatorname{IMP}^{*}\left(d P^{*} / P^{*}\right)+\tau \eta^{C} P^{*} I M(d P / P)
$$

and as a percentage of GDP (equation 7'):

$$
\mathrm{E}_{\mathrm{u}} \mathrm{du} / \mathrm{R}=-\Omega\left(\mathrm{dP}^{*} / \mathrm{P}^{*}\right)+\Omega \tau \eta^{\mathrm{C}}(\mathrm{dP} / \mathrm{P})
$$

As in chapter four, welfare effect is measured under two values of the import's price elasticity $\left(\eta^{\mathrm{C}}\right)$ : -0.5 and -1.5 . The results are presented in table (12) for both welfare effects in terms of money and as a percentage of GDP. The table shows that the total welfare gain of the tariff reduction agreement for the 1995-99 period is negligible. This result was expected since the tariff cut reduces prices by about only one percent $(0.96 \%)$. The gain increases at an increasing rate in the first three years (1995-97), then at a decreasing rate in the last two years (1998-1999). This is because the adjustment in the behavior of consumers and producers to the new environment takes some time. 


\begin{tabular}{lllll}
\hline \multirow{2}{*}{ YEAR } & \multicolumn{3}{c}{ KD million } & \multicolumn{2}{c}{ \% of GDP } \\
& $\eta^{\mathrm{C}}=-0.5$ & $\eta^{\mathrm{C}}=-1.5$ & $\eta^{\mathrm{C}}=-0.5$ & $\eta^{\mathrm{C}}=-1.5$ \\
\hline & & & & \\
1995 & 0.12 & 0.36 & 0.002 & 0.007 \\
1996 & 0.12 & 0.37 & 0.002 & 0.007 \\
1997 & 0.11 & 0.33 & 0.003 & 0.008 \\
1998 & 0.1 & 0.3 & 0.003 & 0.008 \\
1999 & 0.07 & 0.23 & 0.002 & 0.006 \\
& & & & 0.006 \\
\hline
\end{tabular}

Table (12): Effect on Welfare

In terms of money, the total welfare gain is (KD 0.53 million) and (KD 1.6 million) for values of $\left(\eta^{C}\right)$ equal -0.5 and -1.5 , respectively. As a percentage of GDP, the annual welfare gain is between $(0.002 \%)$ and $(0.003 \%)$ for the inelastic demand for imports and between $(0.006 \%)$ and $(0.008 \%)$ for the elastic demand case. These results suggest that the Tariff Reduction Agreement has a minor welfare gain to the Kuwaiti economy, so not much should be expected to be gained, at least, in the short run. In the long run, however, these gains may be higher since the long run compensated price elasticity of imports is much larger than the short run elasticity, which was used here. 


\section{(5.2) ANTIDUMPING AGREEMENT}

As stated in chapter three (section 3.4), the enforcement of this agreement may result in an increase in prices of imports of good (Y) if dumping by foreign suppliers in the Kuwaiti market could be eliminated. This study analyzes the effects of a hypothetical case in which import prices rise by $10 \%$. The effects were measured using the parameters that were estimated in section (4.1). It is assumed that a $10 \%$ increase in import prices has taken place during the 1995-99 period, while prices were kept unchanged for the 1969-94 period.

\section{(5.2.1) EFFECTS ON SUPPLY AND DEMAND}

The effects on supply and demand are presented in table (13). The results show that this agreement has larger effects than those of the tariff reduction agreement since the change in prices is ten times that of the latter agreement. Consumption of good (Y) declined by (KD 498 million) or $(8.8 \%)$, while production increased by (KD 52.2 million) or (1.9\%). This shows that this agreement has different effects on consumers and producers. Consumers have decreased their consumption during the 1995-99 period relative to the baseline (i.e. w/o the agreement) case. Producers, however, enjoy a gain (i.e. higher profits) because the increase in the price was accompanied by an increase in production. The effects on supply and demand are consistent with the laws of supply and demand. 
All numbers in millions of KDs except $\mathrm{L}_{X}$ and $\mathrm{L}_{Y}$ in thousands of employees

\begin{tabular}{lllllllll}
\hline YEAR & $\mathrm{C}_{\mathrm{Y}}$ & $\mathrm{Q}_{\mathrm{Y}}$ & $\mathrm{L}_{\mathrm{Y}}$ & $\mathrm{K}_{\mathrm{Y}}$ & $\mathrm{C}_{\mathrm{X}}$ & $\mathrm{Q}_{\mathrm{X}}$ & $\mathrm{L}_{\mathrm{X}}$ & $\mathrm{K}_{\mathrm{X}}$ \\
\hline 1995 & -97.5 & 10.7 & 1.4 & 7.0 & -3.5 & -18.0 & -0.01 & -0.9 \\
1996 & -101.0 & 10.4 & 1.4 & 7.0 & -5.0 & -18.3 & -0.01 & -0.9 \\
1997 & -106.0 & 11.0 & 1.4 & 7.2 & -3.9 & -16.9 & -0.01 & -0.9 \\
1998 & -103.9 & 10.4 & 1.5 & 7.5 & -2.3 & -29.5 & -0.01 & -0.9 \\
1999 & -89.7 & 9.6 & 1.5 & 7.6 & -2.6 & -28.6 & -0.01 & -0.9 \\
TOTAL & & & & & & & & \\
Million KDs & -498 & 52.2 & 7.4 & 36.3 & -17.3 & -111.3 & -0.04 & -4.4 \\
Percent (\%) & -8.8 & 1.9 & 2.7 & 3.7 & -12.6 & -4.6 & -0.2 & -0.4 \\
\hline
\end{tabular}

Table (13):Effect on Demand and Supply

The demand for capital $\left(\mathrm{K}_{\mathrm{Y}}\right)$ increased by (KD 36.3 million) or $(3.7 \%)$ and the demand for labor $\left(\mathrm{L}_{\mathrm{Y}}\right)$ increased by $(7350$ employees) or $(2.7 \%)$. These two results are consistent with the increase in output. Moreover, the relatively lower increase in demand for labor confirms the observation that the demand for labor is relatively inelastic.

Finally, the effects on the $(\mathrm{X})$ industry are also more significant under this agreement than under the tariff cut agreement. Consumption $\left(\mathrm{C}_{\mathrm{X}}\right)$ declined by $(\mathrm{KD} 17.3$ million) or $(12.6 \%)$. The decline in $\left(\mathrm{C}_{\mathrm{X}}\right)$ implies that the income effect dominates the substitution effect. That is, consumers are poorer as a result of the rise in the price of good (Y). Production $\left(\mathrm{Q}_{\mathrm{X}}\right)$ declined as well by (KD 111.3 million) or (15.5\%) because the increase in the price of good $(\mathrm{Y})$ has increased output $\left(\mathrm{Q}_{\mathrm{Y}}\right)$, which diverted factors of production from producing good $(\mathrm{X})$ to producing good $(\mathrm{Y})$. Demand for labor $\left(\mathrm{L}_{\mathrm{X}}\right)$ declined slightly by $(0.02 \%)$ and demand for capital $\left(\mathrm{K}_{\mathrm{X}}\right)$ decreased by (KD 4.4 million) or $(0.3 \%)$. This shows that demand for capital is more elastic than demand for labor because the $(\mathrm{X})$ industry as in the $(\mathrm{Y})$ industry. The decline in both demand for capital 
and labor is consistent with the decline in output and the increase in demand for factors of production in the $(\mathrm{Y})$ industry. Note that the increase in demand for factors of production in the $(\mathrm{Y})$ industry exceeds the decline in demand for factors in the $(\mathrm{X})$ industry, this creates excess demand for the two factors in the economy.

\section{(5.2.2) EFFECTS ON BALANCE OF TRADE}

This subsection analyzes the effects of the antidumping agreement on the balance of trade. Simulation results are presented in table (14) below. First, imports of good Y $\left(\mathrm{IM}_{\mathrm{Y}}\right)$ decreased by (KD 550.3 million) or $(13.3 \%)$ because the decline in consumption $\left(\mathrm{C}_{\mathrm{Y}}\right)$ was accompanied by an increase in production $\left(\mathrm{Q}_{\mathrm{Y}}\right)$. This resulted in a decline in the excess demand in the economy. As a result, imports have decreased. Second, exports $\left(\mathrm{EX}_{\mathrm{X}}\right)$ decreased by (KD 94 million) or $(17.5 \%)$ because the decline in output $\left(\mathrm{Q}_{\mathrm{X}}\right)$ was by far greater than the decline in consumption $\left(\mathrm{C}_{\mathrm{X}}\right)$. As a result, the excess supply in the economy has decreased and exports decreased as well. Finally, the balance of trade (TB) increased by (KD 456.3 million) as a result of the relatively larger decline in imports to the decline in exports.

\begin{tabular}{llll}
\multicolumn{2}{l}{ All numbers in millions of KDs } & & \\
\hline YEAR & $\mathrm{IM}_{\mathrm{Y}}$ & $\mathrm{EX}_{\mathrm{X}}$ & $\mathrm{TB}$ \\
\hline 1995 & -108.3 & -14.5 & 93.8 \\
1996 & -111.5 & -13.3 & 98.2 \\
1997 & -116.9 & -13.0 & 103.9 \\
1998 & -114.3 & -27.3 & 87.0 \\
1999 & -99.3 & -26.0 & 73.3 \\
TOTAL & & & \\
Million KDs & -550.3 & -94.1 & 456.3 \\
Percent (\%) & -13.3 & -17.5 &
\end{tabular}

Table (14): Effect on Trade Balance 


\section{(5.2.3) EFFECTS ON WELFARE}

In this subsection, the effects of the increase in the price of $(\mathrm{Y})$ on welfare are measured and analyzed. The tool that was used is the same as that of the previous section, namely, the compensating change in utility measure. This measure is estimated both in millions of KDs and as a percentage of GDP.

The welfare loss estimates are presented in table (15). The results show a relatively significant effect of the Antidumping Agreement on the economy of Kuwait. The reason is that the agreement will, hypothetically, increase import prices (domestic prices as well) by ten percent during the period in which it is implemented.

\begin{tabular}{llccc}
\hline \multirow{2}{*}{ YEAR } & \multicolumn{3}{c}{ Kelfare Effect } \\
& $\eta^{\mathrm{C}}=-0.5$ & $\eta^{\mathrm{C}}=-1.5$ & $\eta^{\mathrm{C}}=-0.5$ & $\eta^{\mathrm{C}}=-1.5$ \\
\hline & & & & \\
1995 & -84.4 & -87.7 & -0.02 & -0.08 \\
1996 & -86.9 & -90.4 & -0.02 & -0.08 \\
1997 & -78.5 & -81.5 & -0.03 & -0.08 \\
1998 & -70.9 & -73.7 & -0.03 & -0.08 \\
1999 & -53.8 & -55.9 & -0.02 & -0.06 \\
& & & & -1.55 \\
\hline
\end{tabular}

Table (15): Effect on Welfare

In terms of money, the total welfare loss is (KD 374.5 million) and (KD 389.2 million) for values of $\left(\eta^{C}\right)$ equal -0.5 and -1.5 , respectively. As a percentage of GDP, the annual welfare loss is between $(0.02 \%)$ and $(0.03 \%)$ for the inelastic demand for imports and between $(0.06 \%)$ and $(0.08 \%)$ for the elastic demand case. This loss may even 
increase more in the long run, since the long run compensated price elasticity of imports is much larger than the short run elasticity, which was used here.

These estimates of the welfare loss suggest that the private sector has to play a role in reducing this loss because it is the main beneficiary of enforcing this agreement. For example, it should increase its capacity in the early stages of implementing the agreement in order to reduce the dependency on imports. This was shown to take place (see section 5.2.1) when domestic output of good (Y) was increased during the enforcement period, which resulted in a decline in imports. 


\section{(5.3) DECLINE IN WORLD PRICES}

This subsection provides measures of the effects of a hypothetical $10 \%$ decline in world prices of good $(\mathrm{Y})$ as a result of implementing all of the WTO agreements, which are expected to lower the costs of production and smooth trade (see section 3.4 for more details). This was done by using the simulation procedure assuming a $10 \%$ decrease in import prices for the 1995-99 period, while keeping prices unchanged for the period 1969-94.

\section{(5.3.1) EFFECTS ON SUPPLY AND DEMAND}

The effects on demand and supply are presented in table (16). The results show that the decrease in the price of $(\mathrm{Y})$ has the opposite effects to the price increase with close magnitudes. Consumption of good $(\mathrm{Y})$ rose by (KD 606.6 million) or $(10.7 \%)$, while production declined by (KD 56.6 million) or (2.1\%). Both effects are consistent with the laws of demand and supply, respectively.

All numbers in millions of KDs except $\mathrm{L}_{X}$ and $\mathrm{L}_{Y}$ in thousands of employees

\begin{tabular}{lllllllll}
\hline YEAR & $\mathrm{C}_{\mathrm{Y}}$ & $\mathrm{Q}_{\mathrm{Y}}$ & $\mathrm{L}_{\mathrm{Y}}$ & $\mathrm{K}_{\mathrm{Y}}$ & $\mathrm{C}_{\mathrm{X}}$ & $\mathrm{Q}_{\mathrm{X}}$ & $\mathrm{L}_{X}$ & $\mathrm{~K}_{\mathrm{X}}$ \\
\hline 1995 & 118.8 & -11.7 & -1.5 & -7.4 & 4.5 & 23.8 & 0.01 & 1.0 \\
1996 & 123.1 & -11.3 & -1.6 & -7.4 & 6.4 & 24.1 & 0.01 & 1.0 \\
1997 & 1129.1 & -11.9 & -1.6 & -7.6 & 5.0 & 22.3 & 0.01 & 1.0 \\
1998 & 126.5 & -11.3 & -1.6 & -7.9 & 2.9 & 39.0 & 0.01 & 1.0 \\
1999 & 1109.2 & -10.4 & -1.6 & -8.0 & 3.3 & 37.7 & 0.01 & 1.0 \\
TOTAL & & & & & & & & \\
Million KDs & 606.6 & -56.6 & -7.9 & -38.3 & 22.0 & 147 & 0.04 & 4.9 \\
Percent (\%) & 10.7 & -2.1 & -2.9 & -3.9 & 16.1 & 6.1 & 0.20 & 0.38 \\
& & & & & & & & \\
\hline
\end{tabular}

Table (16):Effect on Demand and Supply 
Demand for labor $\left(\mathrm{L}_{\mathrm{Y}}\right)$ declined by $(7,900$ employees) or $(2.9 \%)$ and demand for capital $\left(\mathrm{K}_{\mathrm{Y}}\right)$ declined as well by (KD 38.3 million) or $(3.9 \%)$. These two results are consistent with the decline in output. Moreover, the relatively higher decrease in demand for capital confirms the observation that labor is relatively inelastic.

Finally, the effect on sector (X) is of a close magnitude and opposite direction to that of the price increase. Consumption $\left(\mathrm{C}_{\mathrm{X}}\right)$ has increased by (KD 22 million) or $(16 \%)$. The increase in $\left(C_{X}\right)$ implies that the income effect dominates the substitution effect. That is, the decline in the price of good $(\mathrm{Y})$ has made the household richer, thus it could afford consuming more of good (X). Production ( $\mathrm{Q}_{\mathrm{X}}$ ) increased by (KD 147 million) or (6.1\%). Demand for labor $\left(\mathrm{L}_{\mathrm{X}}\right)$ increased slightly by (40 employees) or $(0.2 \%)$. Demand for capital $\left(\mathrm{K}_{\mathrm{X}}\right)$ increased by (KD 4.9 million) or $(0.4 \%)$. Again, this shows that demand for capital is more elastic than demand for labor. The rise in both the demand for capital and the demand for labor is consistent with the rise in output $\left(\mathrm{Qx}_{\mathrm{x}}\right)$ and the decline in demand for factors of production in the $(\mathrm{Y})$ industry.

\section{(5.3.2) EFFECTS ON BALANCE OF TRADE}

This subsection discusses the effects of the reduction in the world's price of good (Y) on the balance of trade. Simulation results are presented in table (17) below. First, imports of good $\mathrm{Y}\left(\mathrm{IM}_{\mathrm{Y}}\right)$ increased by (KD 663.3 million) or (16\%) because of the increase in the excess demand in the economy, as a result of the increase in consumption $\left(C_{Y}\right)$ and the decline in production $\left(\mathrm{Q}_{\mathrm{Y}}\right)$. Second, exports $\left(\mathrm{EX}_{\mathrm{X}}\right)$ increased by $(\mathrm{KD} 164.2$ million) or $(30.6 \%)$ because production $\left(\mathrm{Qx}_{\mathrm{x}}\right)$ increased by more than the increase in 
consumption $\left(\mathrm{C}_{\mathrm{X}}\right)$. Finally, the balance of trade (TB) decreased by (KD 499.1 million) as a result of the increase in imports and the decline in exports.

\begin{tabular}{llll}
\multicolumn{2}{l}{ All numbers in millions of KDs } & & TB \\
\hline YEAR & IM $_{\mathrm{Y}}$ & 27.3 & -103.1 \\
\hline 1995 & 130.4 & 29.1 & -105.3 \\
1996 & 134.4 & 26.2 & -114.8 \\
1997 & 141.0 & 41.3 & -96.5 \\
1998 & 137.8 & 40.3 & -79.4 \\
1999 & 119.7 & 164.2 & -499.1 \\
TOTAL & 663.3 & 30.6 & \\
Million KDs & 16.0 & & \\
Percent (\%) & & & \\
\end{tabular}

Table (17): Effect on Trade Balance

\section{(5.3.3) EFFECTS ON WELFARE}

This subsection measures and discusses the effects of the decline in the world's price of good $(\mathrm{Y})$ on welfare. The same tool that was used in the previous sections is used here.

The welfare gain estimates are presented in table (18). The results show a relatively significant effect of the decline in world prices on the Kuwaiti economy. The reason is that the agreement will, hypothetically, reduce import prices (domestic prices as well) by ten percent during the period in which WTO agreements are enforced. In terms of money, the total welfare gain is (KD 374.5 million) and (KD 389.2 million) for values of $\left(\eta^{\mathrm{C}}\right)$ equal -0.5 and -1.5 , respectively. As a percentage of GDP, the annual welfare gain is between $(0.02 \%)$ and $(0.03 \%)$ for the inelastic demand for imports and between $(0.06 \%)$ and $(0.08 \%)$ for the elastic demand case. This gain may even increase more in 
the long run since the long run compensated price elasticity of imports is much larger than the short run elasticity, which was used here.

The main source of this gain, as shown in section (5.3.1), comes from the increase in consumption of both the importable (because of the increase in imports) and the exportable goods. These results encourage all countries to join the WTO, which potentially will improve the world's welfare, ceteris paribus. This of course shows that some countries can "free ride" or take advantage of the improvement in the world welfare as a result of the enforcement of the WTO agreements, without becoming members.

\begin{tabular}{lcccc}
\hline \multirow{3}{*}{ YEAR } & \multicolumn{3}{c}{ KD million } & \multicolumn{2}{c}{ \% of GDP } \\
& $\eta^{\mathrm{C}}=-0.5$ & $\eta^{\mathrm{C}}=-1.5$ & $\eta^{\mathrm{C}}=-0.5$ & $\eta^{\mathrm{C}}=-1.5$ \\
\hline 1995 & 84.4 & 87.7 & 0.02 & 0.08 \\
1996 & 86.9 & 90.4 & 0.02 & 0.08 \\
1997 & 78.5 & 81.5 & 0.03 & 0.08 \\
1998 & 70.9 & 73.7 & 0.03 & 0.08 \\
1999 & 53.8 & 55.9 & 0.02 & 0.06 \\
TOTAL & 374.5 & 389.2 & 1.47 & 1.55 \\
\end{tabular}

Table (18): Effect on Welfare 


\section{(5.4) GOVERNMENT PROCUREMENT AGREEMENT}

This subsection hypothesizes the effects of implementing the Government Procurement Agreement, which prohibits governments from discriminating against foreign suppliers. Here it is assumed that $50 \%$ of the government's purchases of goods (X and $\mathrm{Y}$ ) are in excess of what it needs, just to support domestic producers. This makes these purchases subject to the rules of the government procurement agreement.

As mentioned in chapter three (section 3.4), only exports of good (X) are affected by this agreement; there is no effect on supply and demand. The results show that exports will increase by (KD 22.6 million) or (4.1\%) as a result of implementing this agreement, ceteris paribus. As a result, the balance of trade increased by the same amount since imports haven't changed.

\begin{tabular}{lll} 
All numbers in millions of KDs & & \\
\hline YEAR & $\mathrm{EX}_{\mathrm{X}}$ & $\mathrm{TB}$ \\
\hline 1995 & 4.2 & 4.2 \\
1996 & 4.1 & 4.1 \\
1997 & 4.2 & 4.2 \\
1998 & 4.9 & 4.9 \\
1999 & 5.2 & 5.2 \\
TOTAL & & \\
Million KDs & 22.6 & 22.6 \\
Percent (\%) & 4.1 & 4.1 \\
& & \\
\hline
\end{tabular}

Table (19): Effect on Trade Balance 


\section{CHAPTER (6)}

\section{CONCLUSIONS}

\section{(6.1) EXTENSIONS}

This study can be extended in a number of directions to get more insights of the possible effects of the WTO on the economy of Kuwait. First, the assumptions of perfect competition and constant returns to scale may be replaced by assumptions of imperfect competition and economies of scale. It would be interesting to see how the results will change under these new assumptions, especially since previous studies have shown that these new assumptions double or triple the estimates of the gains from the WTO agreements. Second, a different model may be used to obtain new estimates that can be compared to the estimates obtained in this study. For example, a partial equilibrium model may be used to obtain estimates of gains or losses of a certain sector (s) of the economy as a result of enforcing a given agreement (s). Third, the model may be used to get estimates of the effects of the WTO on other sectors of the economy and other import categories. For example, we may look at the effects of trade liberalization agreements on imports of food, capital goods and crude materials; or on exports of oil, which is still outside the scope of the WTO agreements. Finally, the model can be used to get estimates of the WTO on a group of countries in which Kuwait is a member. For example, it may 
be appropriate to use panel data for country members of the Organization of Petroleum Exporting Countries (OPEC) or members of the Gulf Cooperation Council (GCC).

\section{(6.2) SUMMARY}

The major contribution of this study was quantifying the economic impact of Kuwait's membership in the World Trade Organization (WTO). The study has provided quantitative measures of the effects on supply, demand, welfare and terms of trade of Kuwait. The significance of this study comes from being the first study to quantify the effects on Kuwait since joining the WTO.

A general equilibrium international trade model was used to obtain the quantitative results. The model is theoretically static and based on the assumptions of perfect competition and constant returns to scale. However, it was estimated dynamically by including a lagged dependent variable in each estimated equation and it was simulated dynamically as well. The model describes the behavior of three representative economic agents in a small open economy. The model emphasizes the effects of the WTO agreements on trade in two bundles of manufactured goods that are produced by the representative firm. The first is an importable good which corresponds to a bundle of manufactured goods (excludes capital goods, crude materials and agricultural products). The second is an exportable good that represents a bundle of chemical goods. The government produces public services that are consumed domestically and oil that is exported to the foreign country.

After specifying the model theoretically, it was estimated empirically using annual real data for the period between 1969 and 1999. This study has linearized the 
supply and demand equations that were obtained from solving the optimization problems of the household and the firm, then it used econometric techniques to estimate the model. This is in contrast with other studies that usually solve general equilibrium models numerically, because they are nonlinear and complicated, using a technique known as "calibration." The main objective of estimating the model was to provide a quantitative measure of the WTO agreements on the Kuwaiti economy. The estimated model was used in a number of simulation exercises, in each one a given agreement was analyzed and economic effects were measured.

The simulation exercises gave a number of results that are summarized in tables (21 and 22). Below is a discussion of the effects on good (Y) only since it was affected by the WTO agreements that were analyzed. First, the agreement on tariff reduction has a very small effect on Kuwait because tariff rates are already low, making any reductions have insignificant effects. The results are as follows: Consumption of the importable good increased by $0.9 \%$, its production declined by $0.15 \%$, its imports increased by 1.4 $\%$ and the welfare gain was between $0.002 \%$ and $0.006 \%$ (depending on the elasticity of imports). Second, the antidumping agreement has a larger effect since it corresponds hypothetically to a $10 \%$ increase in the price of the importable good. The results are as follows: Consumption of the importable good declined by $8.8 \%$, its production increased by $1.9 \%$, its imports declined by $13.3 \%$ and the welfare loss was between $1.47 \%$ and $1.55 \%$. Third, the decline in the world's price of the importable good as a result of implementing the WTO agreements globally, has significant effects on the economy. The results are as follows: Consumption of the importable good increased by $10.7 \%$, its production declined by $2.1 \%$, its imports increased by $16 \%$ and the welfare gain was 
between $1.47 \%$ and $1.55 \%$. Finally, the agreement on government procurement has the least effects since it affects only exports of the exportable good, which increased by 4.1 $\%$.

All numbers are in percentage rates

\begin{tabular}{lllllllllll}
\hline Case & CY & QY & LY & KY & CX & QX & LX & KX \\
\hline
\end{tabular}

\section{Tariff}

$\begin{array}{lllllllll}\text { Reduction } & 0.94 & -0.15 & -0.27 & -0.34 & 1.37 & 0.5 & 0.02 & 0.04\end{array}$

$\begin{array}{lllllllll}\text { Antidumping } & -8.8 & 1.86 & 2.7 & 3.7 & -12.6 & -4.6 & -0.2 & -0.34\end{array}$

Decline

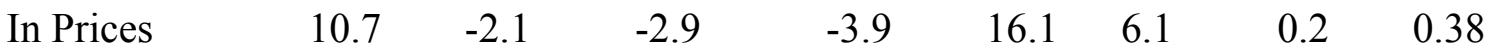

Government

Procurement

\begin{tabular}{llllllll}
0 & 0 & 0 & 0 & 0 & 0 & 0 & 0 \\
\hline
\end{tabular}

Table (20): Summary of Effects on Supply and Demand.

All numbers are in percentage rates

\begin{tabular}{ll}
\hline Case & IMY \\
\end{tabular}

Tariff

Reduction

1.4

1.9

Antidumping

$-13.3$

$-17.5$

Decline

In Prices

16.0

30.6

Government

Procurement 0

4.1

Table (21): Summary of Effects on Imports and Exports. 


\section{(6.3) Conclusions}

The results obtained in this study have a number of features that can be used to draw a number of conclusions. First, each agreement has different effects than other agreements in terms of the direction of effects (i.e. positive vs. negative) and their magnitudes. Second, each agreement affects economic agents (i.e. households and firms) in opposite directions. For example, an increase in the prices hurts consumers but benefits producers. Third, from the above points, it is clear that no general (uniform) conclusions can be drawn regarding the effects of the agreements of the WTO as a whole. Instead, the agreements have to be evaluated on individual agreement basis and, specifically, on the basis of individual economic agents. Fourth, even producers are affected differently in the two sectors (i.e. $\mathrm{X}$ and $\mathrm{Y}$ ) under each agreement, which makes it more difficult to draw general conclusions. Fifth, exports and imports tend to move in the same direction but at different magnitudes. Finally, the relatively low estimates obtained in this study may be contributed to the restrictive assumptions of the model such as perfect competition and constant returns to scale. It is clear that relaxing these assumptions may significantly increase the estimates (Francois et al, 1994). 


\section{REFERENCES}

Abdulghani, N. 1991. “A Macroeconometric Model of the Gulf State of Kuwait.”UMI Dissertation Services. Ann Arbor, Michigan.

Agarwala, R. 1970. “An Econometric Model of India.” London: Frank Cass.

Algahtani, I. 1992. "Currency Substitution, Gold Price and Demand for Money in A Developing Economy: The Case of Kuwait." The Middle East Business and Economics Review, 4: 1-5.

Alomar, M. 2002. "Why the Rentier Economy Fails in Economic Development? The Case of Kuwait.” Ph.D. Dissertation, Claremont Graduate University.

Anderson, J. and J. Neary. 1992. "Trade Reform With Quotas, Partial Rent Retention, and Tariffs." Econometrica 60: 57-76.

Anderson, J. and W. Martin. 1995. "The Welfare Analysis of Fiscal Policy: A Simple Unified Account.” Boston College, Mimeo.

Armington, P. 1969. “A Theory of Demand for Products Distinguished by Place of Production.” IMF Staff Papers 16:179-201.

Arrow, K. and G. Debreu. 1954. "Existence of an Equilibrium for a Competitive Economy." Econometrica, 22:265-90.

Arrow, K. and F. Hahn. 1971. "General Competitive Analysis.” San Francisco, CA: Holden-Day.

Auerbach, A. 1985. “The Theory of Excess Burden and Optimal Taxation.” In Handbook of Public Finance, Chapter 2. 
Backus, D., P. Kehoe and F. Kydland. 1992. "International Real Business Cycles.” The Journal of Political Economy, 100: 745-75. . 1993. "International Business Cycles: Theory Vs. Evidence.” Federal Reserve Bank of Minneapolis Quarterly Review, 14-29. . 1994. "Dynamics of the Trade Balance and the Terms of Trade: The J-Curve?" The American Economic Review, 84: 84-103.

Bandara, K.1991. "Computable General Equilibrium Models for Development Policy Analysis in LDCs." Journal of Economic Surveys, 5: 3-69.

Breusch, T. 1978. "Testing for Autocorrelation in Dynamic Linear Models." Australian Economic Papers, 17: 334-55.

Brown, D., A. Deardorff, A. Fox and R. Stern. 1996. "Computational Analysis of Goods and Services Liberalization in the Uruguay Round." In W. Martin and L. Winters, "The Uruguay Round and the Developing Economies.

Brown, F. and J. Whalley. 1980. "General Equilibrium Evaluations of Tariff-Cutting Proposals in the Tokyo Round and Comparisons with More Extensive Liberalization of World Trade." The Economic Journal, 90: 838-866.

Carter, N. 1970. “A Macroeconometric Model of Jamaica 1959-1966." Social and Economic Studies, 19: 178-201.

Central Bureau of Statistics. 1984. "ELSA-Indonesia Model." In Tokyo Institute of Developing Economies "Preliminary Results of Econometric Models in the ELSA Project: Vol II." 
Cline, W., N. Kawanabe, T. Kronsjo and T. Williams. 1978. "Trade Negotiations in the Tokyo Round: A quantitative Assessment." Washington, DC: The Brookings Institute.

Cochrane, D. and G. Orcutt. 1949. "Application of Least Squares Regressions to Relationships Containing Autocorrelated Error Terms." Journal of the American Statistical Association.”, 44: 32-61.

Crockett, A. and O. Evans. 1980. "Demand for Money in Middle Eastern Countries." IMF Staff Papers, No. 27.

De Melo, J. and D. Tarr. 1990. "Welfare Costs of U.S. Quotas in Textiles, Steel and Autos." The Review of Economics and Statistics, 72: 489-97.

Diamond, P and D. McFadden. 1974. "Some Uses of the Expenditure Function in Public Finance." Journal of Public Finance, 3:3-21.

Dixit, A. 1975. "Welfare Effects of Tax and Price Changes." Journal of Public Economics, 4:103-123.

Dixit, A. and V. Norman. 1980. "Theory of International Trade." Cambridge University Press.

Downing, L. and J. Solis. 1979. "An Econometric Model for Nicaragua." In J. Behrman and J. Hanson "Sort-Term Macroeconomic Policy in Latin America."

Durbin, J. 1970. "Testing for Serial Correlation in Least-Squares Regression When Some of the Regressors Are Lagged Dependent Variables." Econometrica, 38: 410-21. and G. Watson. 1951. "Testing for Serial Correlation in Least-Squares Regression.” Biometrika, 38: 159-71. 
El Mallkh, R. and J. Atta. 1981. "The Absorptive Capacity of Kuwait.” Lexington, D.C. Health and Company.

Fadil, F. 1989. "Money, Income and Sterilization: Tests for Causality in the Oil Economy of Kuwait.” Applied Economics, 29: 1305-24.

Feenstra, R. 1992. "How Costly is Protectionism." The Journal of Economic Perspectives, 6: 159-78.

Floyd, J. 1965. "The Overvaluation of the Dollar." The American Economic Review, 55: 95-107.

Francois, J., B. McDonald and H. Nordstrom. 1994. "The Uruguay Round: A global General Equilibrium Assessment.” CEPR Discussion Paper.

Godfrey, L. 1978. “Testing Against General Autoregressive and Moving Average Error Models When the Regressors Include Lagged Dependent Variables.” Econometrica, 46: $1293-302$

Goldin, I., D. Knudsen and D. Mensbrugghe. 1993. "Trade liberalization: Global Economic Implications.” OECD and the World Bank, Paris.

Hansen, G. 1985. “Indivisible Labor and the Business Cycle.” Journal of Monetary Economics, 16: 309-27.

Harris, R. 1984. “Applied General Equilibrium Analysis of Small Open Economies with Scale Economies and Imperfect Competition.” The American Economic Review, 74: 1016-1032.

Hartigan, J. and E. Tower. 1982. "Trade Policy and the American Income Distribution." The Review of Economics and Statistics, 64: 261-70. 
Hatta, T. and T. Fukushima. 1979. "The Welfare Effect of Tariff Rate Reductions in a Many Country World.” Journal of International Economics, 9: 503-11.

Hausman, J. 1981. “Exact Consumer's Surplus and Deadweight Loss.” The American Economic Review, 71: 662-76.

Heckscher, E. 1949. “The Effect of Foreign Trade on the Distribution of Income.” In H. Ellis and L. Metzler "Readings in the Theory of International Trade." Philadelphia: Blakiston.

Hegazey, E. 1985. "The Contribution of Oil to the Economic Development in Kuwait (1962-81): A Macroeconometric Approach." University Microfilms International. Ann Arbor, Michigan.

Hertel, T., W. Martin, K. Yanagishima and B. Dimaranan. 1996. "Liberalizing Manufactures in a Changing World Economy." In W. Martin and L. Winters, "The Uruguay Round and the Developing Economies.

Hicks, J. 1942. “Consumer's Surplus and Index-Numbers.” Review of Economic Studies, 9: 126:37.

Houthakker, H. and S. Magee. 1969. "Income and Price Elasticities in World Trade." The Review of Economics and Statistics, 51: 111-25.

Hufbauer, G. 1996. "Surveying the Costs of Protection: A Partial Equilibrium Approach.” In J. Schott, “The World Trading System: Challenges Ahead.”

Huff, K. 1999. "Uncovering the Sources of the Uruguay Round Gains and Losses: A Welfare Decomposition Approach.” Ph.D. Dissertation, Purdue University. 
Imaoka, H. and S. Meyanathan. 1984. " A Survey of Macroeconometric Models for Malaysia." In Tokyo: Institute of Developing Economies "Review of National Economies and econometric Models in the ELSA Project: Vol. 1.”

Jackson, J. 1998. “The World Trade Organization: Constitution and Jurisprudence.” The Royal Institute of International Affairs, London: UK.

Kay, J. 1980. "The Deadweight Loss from a Tax System.” Journal of Public Economics, 13: 111-19.

Khayum, M. 1991. "Macroeconomic Modeling and Policy Analysis for Less Developed Countries.” Westview Press: Boulder - San Francisco - Oxford.

Khoja, M and P. Sadler. 1979. "The Economy of Kuwait: Development and Role in International Finance.” The Macmillan Press Ltd.

Kwack, S. 1986. "Policy Analysis with a Macroeconomic Model of Korea." Economic Modelling, 3: 175-96.

Kydland, F. and E. Prescott. 1982. "Time to Build and Aggregate Fluctuations." Econometrica, 50: 1345-70.

Lin, T. and W. Chou. 1985. "Hong Kong Model.” In S. Ichimura and M. Ezaki “Econometric Models of Asian Link.” Tokyo: Springer-Verlag.

Lloyd, P. and A. Schweinberger. 1988. "Trade Expenditure Functions and the Gains from Trade." Journal of International Economics, 24: 275-97.

Lucas, R. 1976. "Econometric Policy Evaluation: A Critique.” In K. Brunner and A. Meltzer "The Phillips Curve and Labor Markets." American Elsevier:New York Magee, S. 1975. "Prices, Incomes and Foreign Trade.” In P. Kenen, "International Trade and Finance: Frontiers for Rearch.” Cambridge University Press. 
Marion, N. and L. Svensson. 1986. "The Terms of Trade Between Oil Importers.” Journal of International Economics, 20: 99-113.

Martin, W. and J. Alston. 1994. “ A Dual Approach to Evaluating Research Benefits in the Presence of Distortions." American Journal of Agricultural Economics, 76: 26-35. Martin, W. 1997. "Measuring Welfare Changes With Distortions.” In J. Francois and K. Reinert "Applied Methods for Trade Policy Analysis A Handbook." Cambridge, University Press.

Marwah, K. 1969. “An Econometric Model of Columbia: A Prototype Devaluation View." Econometrica, 37:228-51.

Maynard, G. and V. Rijckegham.1968. "Stabilization Policy in an Inflationary Economy: Argentina.” In G. Papanek “Development Policy: Theory and Practice.” Cambridge: Harvrd University Press.

Ministry of Planning, Kuwait. Annual Statistical Abstract, several issues.

Mishan, E. 1960. "Survey of Welfare Economic, 1939-59." The Economic Journal, 70: 197-256.

Moosa, I. 1986. “An Econometric Model of Kuwait's Monetary Sector.” The Industrial Bank of Kuwait Working Papers, 22: 1-143.

Morgan, D. 1979. "Fiscal Policy in Oil Exporting Countries, 1972-78." International Monetary Fund Staff Ppaers, 26: 55-86.

Nguyen, T., C. Perroni and R. Wigle. 1993. "An Evaluation of the Draft Final Act of the Uruguay Round.” The Economic Journal, 103: 1540-58.

OECD. 1998. "Open Markets Matter, The Benefits of Trade and Investment Liberalization.” OECD, Paris. 
Ohlin, B. 1933. "Interregional and International Trade." Cambridge: Harvard University Press.

Orcutt, G. 1950. "Measurement of Price Elasticities in International trade." Review of Economics and Statistics, 32: 117-32.

Paul, L. 1978. "Export Simulations of the Guyanese Economy." Ph.D. Dissertation, Howard University.

Perera, N. 1994. "The Demand for Money in the Members of the Gulf Cooperation Council: Evidence from Cointegration Tests." The Middle East Business and Economics Review, 6: 10-26.

Perroni, C. 1998. "The Uruguay Round and its Impact on Developing Countries: An Overview of Model Results.” In T. Harmon and J. Whalley “Uruguay Round Results and the Emerging Trade Agenda." United Nations: New York and Geneva.

Persad, U. 1975. “An Econometric Model of Trinidad and Tobago 1960-1971.” Social and Economic Studies, 24: 389-419.

Pindyck, R. and D. Rubinfeld. 1991. "Econometric Models and Economic Forecasts." Third Edition, McGraw-Hill Inc.

Ricardo, D. 1817. “The Principles of Political Economy and Taxation.” Homewood, IL: Irwin, 1963.

Samuelson, P. 1948. "International Trade and the Equalization of Factor Prices."

Economic Journal, 58: 163-84.

Sangarabalan, S. 1984. "Macroeconomic Planning in Kuwait: An Econometric Simulation Approach.” Ph.D. Dissertation: University of Surrey. 
Scarf, H. 1967. "On the Computation of Equilibrium Prices." In W. Fellner "Ten Economic Studies in the Tradition of Irving Fisher.", NY: Wiley.

Small, K. and H. Rosen. 1981. “Applied Welfare Economics with Discrete Choice Models." Econometrica, 49: 105-130.

Soonthornsima, C. 1964. "A Macroeconomic Model for Economic Development of Thailand.” Institute of Public Administration, Bangkok: Thammasat University. Thurman, W. 1993. "The Welfare Significance and Nonsignificance of General Equilibrium Demand and Supply Curves.” Public Finance Quarterly, 21: 449-69.

Toida, M. 1984. “ELSA-Singapore Model.” In Tokyo: Institute of Developing Economies "Preliminary Results of Econometric Models in the ELSA Project: Vol. II."

Trela, I. And J. Whalley. 1990. "Global Effects of Developed Country Trade Restrictions on Textiles and Apparel.” The Economic Journal, 100: 1190-1205.

Tyers, R. and R. Falvey. 1989. "Border Price Changes and Domestic Welfare in the Presence of Subsidized Exports.” Oxford Economic Papers, 41: 434-51.

UNCTAD, 1973. "Models for Developing Countries." In R. Ball "The International Linkage of National Economic Models.” Amsterdam: North-Holland.

Van Wincoop, E. 1996. "A Multi-Country Real Business Cycle Model with Heterogeneous Agents." Scandinavian Journal of Economics, 98: 233-51.

Varian, H. 1992. "Microeconomic Analysis." W.W. Norton \& Company, New YorkLondon.

Vousden, N. 1990. "The Economics of Trade Protection." Cambridge University Press, Cambridge. 
Whalley, J. 1975. “A General Equilibrium Assessment of the 1973 United Kingdom Tax Reform." Economica, 42: 139-61.

World Trade Organization. 1999a. "Guide to the Uruguay Round Agreements." Kluwer Law International, The Hague. London. Boston.

World Trade Organization, 1999b. "The Legal Texts.” Cambridge University Press. 
APPENDICES 


\section{APPENDIX (1)}

\section{GRAPHICAL ANALYSIS}

In the graph below (from Corden, 1971, p. 67 ), a small country is trading in two goods X (exportable) and Y (importable). The graph was used by Corden to show the effect of imposing an import tariff on $\mathrm{Y}$ beginning from a free trade case. However, since our goal in this study is to examine the effects of reducing tariffs on the terms of trade and welfare of the home country, the graph is used inversely. That is, beginning from a case of import tariffs and move to a case of reducing tariffs.

First, the production possibility curve is drawn, using factor endowments and production functions, and labeled as $\mathrm{HH}^{\prime}$. Second, the tariff distorted price ratio is labeled as GG'. Thus, production is determined at point P' where HH' tangents GG'. Third, the income-consumption line, associated with the price ratio GG', is 0Z'. Consumption point is determined as follows. The country can trade along the line JP'J' which is parallel to the tariff free price ratio line SS'. Consumption must be on the $0 \mathrm{Z}^{\prime}$ line, therefore, consumption point must be at the intersection of lines JP'J' and 0Z' at point C'. To determine imports, exports and tariff revenues, draw line LL' parallel to GG' (the difference between them is the recycled tariff revenue) and passes through C'. Consumption of Y is D'C' of which D'D is produced domestically and DC' is imported. Production of $\mathrm{X}$ is $0 \mathrm{~K}^{\prime}$ of which $0 \mathrm{D}^{\prime}$ is domestically consumed while $\mathrm{D}$ ' $\mathrm{K}$ ' is exported. The trade triangle, under the tariff, is DP'C'. Finally, the tariff revenue is P'E which is returned to the households' as transfers. 
Next, we consider the case when import tariffs by the home country are reduced (or eliminated). First, the reduction in tariff rate on $(\mathrm{Y})$ increases the relative price ratio (terms of trade) which rotates the relative price curve which becomes steeper, SS'. As a result, the tangency (production) point becomes $\mathrm{P}$ and the income-consumption curve becomes steeper, 0Z. Second, the intersection (consumption) point between SS' and $0 \mathrm{Z}$ is now higher and to the left of $\mathrm{C}^{\prime}$. This implies that the consumption of $\mathrm{Y}$ has increased and the consumption of $\mathrm{X}$ has decreased. Third, the new trade triangle is now CBP, which is much greater than the previous trade triangle with higher tariffs. Exports of $\mathrm{X}$ increased to BP, while imports of Y increased to BC. 


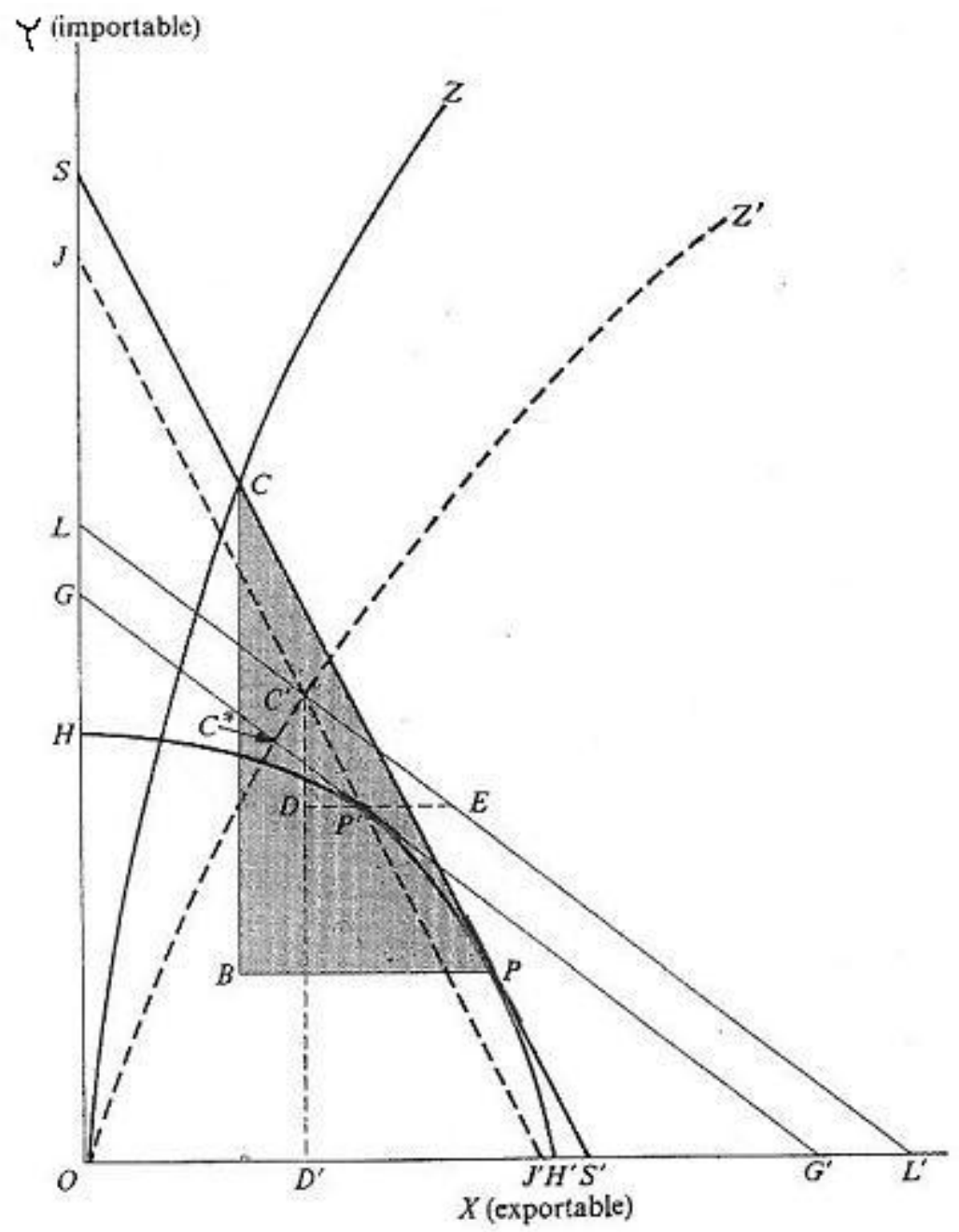




\section{APPENDIX (2)}

\section{Deriving The Compensated Price Elasticity of Imports}

The Slutsky equations is defined as follows:

$\partial \mathrm{IM}^{\mathrm{U}} / \partial \mathrm{P}=\partial \mathrm{IM}^{\mathrm{C}} / \partial \mathrm{P}-\mathrm{IM} \partial \mathrm{IM}^{\mathrm{U}} / \partial \mathrm{R}$

Multiply both sides by P/IM to obtain elasticities,

$\partial \mathrm{IM}^{\mathrm{U}} / \partial \mathrm{P} \mathrm{P} / \mathrm{IM}=\partial \mathrm{IM}^{\mathrm{C}} / \partial \mathrm{P} \mathrm{P} / \mathrm{IM}-\mathrm{IM} \partial \mathrm{IM}^{\mathrm{U}} / \partial \mathrm{R}$ P/IM

$\eta^{\mathrm{U}}=\eta^{\mathrm{C}}-\mathrm{IM} \partial \mathrm{IM}^{\mathrm{U}} / \partial \mathrm{R}$ P/IM

Multiply the second term on the right hand side by IM/R and R/IM

$\eta^{\mathrm{U}}=\eta^{\mathrm{C}}-\eta^{\mathrm{R}} \mathrm{P} \mathrm{IM} / \mathrm{R}$

Define $\Psi=\mathrm{P}$ IM / $\mathrm{M}$ as the share of imports in total income

$\eta^{\mathrm{U}}=\eta^{\mathrm{C}}-\Psi \eta^{\mathrm{R}}$

Solve for the compensated elasticity of demand for imports,

$\eta^{\mathrm{C}}=\eta^{\mathrm{U}}+\Psi \eta^{\mathrm{R}}$ 


\section{APPENDIX (3)}

Table (22) GATT Rounds and Volume of Trade Covered (\$ billion)

\begin{tabular}{llcc}
\hline Round & Dates & $\begin{array}{l}\text { Number of } \\
\text { Countries }\end{array}$ & $\begin{array}{c}\text { Value of Trade } \\
\text { Covered (\$ bn) }\end{array}$ \\
\hline Geneva & 1947 & 23 & 10 \\
Annecy & 1949 & 33 & NA \\
Torquay & 1950 & 34 & NA \\
Geneva & 1956 & 22 & 2.5 \\
Dillon & $1960-61$ & 45 & 4.9 \\
Kennedy & $1962-67$ & 48 & 40 \\
Tokyo & $1973-79$ & 99 & 155 \\
Uruguay & $1986-94$ & 120 & 3,700 \\
\hline
\end{tabular}

Source: Jackson (1998). 


\section{APPENDIX (4)}

\section{$\underline{\text { Table (23) WTO Agreements }}$}

LIST OF ANNEXES

\section{ANNEX (1)}

\section{ANNEX 1A Multilateral Agreements on Trade in Goods}

General Agreement on Tariffs and Trade 1994

Agreement on Agriculture

Agreement on the Application of Sanitary and Phytosanitary Measures

Agreement on Textiles and Clothing

Agreement on Technical Barriers to Trade

Agreement on Trade-Related Investment Measures

Agreement on Implementation of Article VI of the General Agreement on

Tariffs and Trade 1994

Agreement on Implementation of Article VII of the General Agreement on

Tariffs and Trade 1994

Agreement on Preshipment Inspection

Agreement on Rules of Origin

Agreement on Import Licensing Procedures

Agreement on Subsidies and Countervailing Measures

Agreement on Safeguards

\section{ANNEX 1B General Agreement on Trade in Services and Annexes}

ANNEX 1C Agreement on Trade-Related Aspects of Intellectual Property Rights 
Table (23)...Continue

ANNEX (2)

Understanding on Rules and Procedures Governing the Settlement of Disputes

ANNEX (3)

Trade Policy Review Mechanism

ANNEX (4)

\section{Plurilateral Trade Agreements}

Agreement on Trade in Civil Aircraft

Agreement on Government Procurement

International Dairy Agreement

International Bovine Meat Agreement

Source: WTO: The Legal Text (1999) 


\section{APPENDIX (5)}

Table (24) Survey of Time-Series Studies in LDCs

\begin{tabular}{|c|c|c|c|}
\hline Author & Country & Year & Number of Observations \\
\hline Agarwala & India & 1970 & 14 \\
\hline Carter & Jamaica & 1970 & 8 \\
\hline \multicolumn{4}{|l|}{ Central Bureau } \\
\hline Statistics & Indonesia & 1984 & 22 \\
\hline \multicolumn{4}{|l|}{ Downing and } \\
\hline Solis & Nicaragua & 1979 & 15 \\
\hline \multicolumn{4}{|l|}{ Imaoka and } \\
\hline Neyanathan & Malaysia & 1984 & 16 \\
\hline Lin and Chou & Hong Kong & 1985 & 20 \\
\hline Marwah & Columbia & 1969 & 12 \\
\hline \multicolumn{4}{|l|}{ Maynard and } \\
\hline Rijckeghem & Argentina & 1968 & 16 \\
\hline Paul & Guyana & 1975 & 22 \\
\hline Persad & Trinidad and Tobago & 1975 & 12 \\
\hline Soonthornsima & Thailand & 1964 & 9 \\
\hline Toida & Singapore & 1984 & 16 \\
\hline UNCTAD & Nigeria & 1973 & 12 \\
\hline
\end{tabular}

Source: Khayum (1991) 


\section{APPENDIX (6)}

Table (25) Survey of Time-Series Studies of Kuwait

\begin{tabular}{lccl}
\hline Author & Year & Number of Observations & \multicolumn{1}{c}{ Type of Study } \\
\hline Abdulghani & 1991 & 28 & Ph.D. Dissertation: \\
Algahtani & 1992 & 32 (quarterly) & Journal Article \\
Alomar & 2002 & 21 & Ph.D. Dissertation: \\
& & & Claremont Graduate \\
Crockett and Evans & 1980 & 7 & University \\
El Mallakh and & & & IMF Staff Paper \\
Atta & 1981 & 16 & \\
Fadil & 1989 & 44 (quarterly) & Journal Article \\
Hegazey & 1985 & 20 & Ph.D. Dissertation: \\
& & & University of Connecticut \\
Khoja and Sadler & 1979 & 15 & Book \\
Moosa & 1986 & 24 (quarterly) & Working Paper \\
Perera & 1994 & 44 (quarterly) & Journal Article \\
Sangarabalan & 1984 & 18 & Ph.D. Dissertation: \\
& & & University of Surrey \\
\hline
\end{tabular}




\section{APPENDIX (7)}

Table (26) Estimation of Supply and Demand: Baseline

\begin{tabular}{|c|c|c|c|c|c|c|c|}
\hline Dependent Variable & $\mathrm{P}_{\mathrm{Y}}$ & $\mathrm{P}_{\mathrm{X}}$ & $\mathrm{L}$ & $\mathrm{K}$ & $\mathrm{T}$ & $\mathrm{EX}_{\mathrm{OIL}}$ & Lag \\
\hline $\mathrm{Q}_{\mathrm{X}}$ & $\begin{array}{l}-1.8 \\
(-3.2)\end{array}$ & $\begin{array}{l}1.1 \\
(3.4)\end{array}$ & $\begin{array}{l}0.8 \\
(1.4)\end{array}$ & $\begin{array}{c}0.3 \\
(0.8)\end{array}$ & ---- & $\begin{array}{l}0.9 \\
(6.2)\end{array}$ & $\begin{array}{c}0.2 \\
(0.1)\end{array}$ \\
\hline $\mathrm{Q}_{\mathrm{Y}}$ & $\begin{array}{l}0.2 \\
(0.8)\end{array}$ & $\begin{array}{c}0.2 \\
(1.5)\end{array}$ & $\begin{array}{l}-0.4 \\
(-1.2)\end{array}$ & $\begin{array}{l}0.6 \\
(3.3)\end{array}$ & ---- & $\begin{array}{l}0.2 \\
(2.8)\end{array}$ & $\begin{array}{l}0.1 \\
(1.0)\end{array}$ \\
\hline $\mathrm{C}_{\mathrm{X}}$ & $\begin{array}{l}-1.4 \\
(-1.4)\end{array}$ & $\begin{array}{l}2.9 \\
(6.5)\end{array}$ & $\begin{array}{l}-4.9 \\
(-5.5)\end{array}$ & $\begin{array}{l}2.9 \\
(4.9)\end{array}$ & $\begin{array}{l}-0.9 \\
(-0.9)\end{array}$ & ---- & $\begin{array}{l}0.01 \\
(0.1)\end{array}$ \\
\hline $\mathrm{C}_{\mathrm{Y}}$ & $\begin{array}{l}-0.9 \\
(-1.6)\end{array}$ & $\begin{array}{l}0.7 \\
(3.1)\end{array}$ & $\begin{array}{l}-0.8 \\
(-2.4)\end{array}$ & $\begin{array}{l}0.9 \\
(3.8)\end{array}$ & $\begin{array}{l}0.9 \\
(2.3)\end{array}$ & ---- & $\begin{array}{l}0.5 \\
(3.1)\end{array}$ \\
\hline $\mathrm{K}_{\mathrm{X}}$ & $\begin{array}{l}-0.04 \\
(-0.1)\end{array}$ & $\begin{array}{l}-0.1 \\
(-0.5)\end{array}$ & $\begin{array}{l}-0.5 \\
(-1.4)\end{array}$ & $\begin{array}{l}1.1 \\
(5.2)\end{array}$ & ---- & $\begin{array}{l}-0.1 \\
(-1.9)\end{array}$ & $\begin{array}{l}0.5 \\
(4.4)\end{array}$ \\
\hline $\mathrm{K}_{\mathrm{Y}}$ & $\begin{array}{l}0.4 \\
(1.1)\end{array}$ & $\begin{array}{l}-0.4 \\
(-2.5)\end{array}$ & $\begin{array}{l}-0.1 \\
(-0.2)\end{array}$ & $\begin{array}{l}0.5 \\
(2.1)\end{array}$ & ---- & $\begin{array}{l}0.1 \\
(0.8)\end{array}$ & $\begin{array}{l}0.6 \\
(3.3)\end{array}$ \\
\hline $\mathrm{L}_{\mathrm{X}}$ & $\begin{array}{l}-0.02 \\
(-0.1)\end{array}$ & $\begin{array}{l}0.3 \\
(1.9)\end{array}$ & $\begin{array}{l}-0.3 \\
(-1.1)\end{array}$ & $\begin{array}{l}0.4 \\
(2.1)\end{array}$ & ---- & $\begin{array}{l}0.03 \\
(0.4)\end{array}$ & $\begin{array}{l}0.7 \\
(5.0)\end{array}$ \\
\hline $\mathrm{L}_{\mathrm{Y}}$ & $\begin{array}{l}0.3 \\
(1.1)\end{array}$ & $\begin{array}{l}-0.01 \\
(-0.1)\end{array}$ & $\begin{array}{l}0.04 \\
(0.1)\end{array}$ & $\begin{array}{l}0.1 \\
(0.9)\end{array}$ & ---- & $\begin{array}{c}0.04 \\
(0.8)\end{array}$ & $\begin{array}{l}0.6 \\
(2.8)\end{array}$ \\
\hline
\end{tabular}

Note: numbers in parentheses are t-statistics. 


\section{APPENDIX (8)}

Table (27) Estimation of Supply and Demand: w/o T and EX $\mathrm{XIL}_{\mathrm{O}}$

\begin{tabular}{|c|c|c|c|c|c|}
\hline Dependent Variable & $\mathrm{P}_{\mathrm{Y}}$ & $\mathrm{P}_{\mathrm{X}}$ & $\mathrm{L}$ & $\mathrm{K}$ & Lag \\
\hline $\mathrm{Q}_{\mathrm{X}}$ & $\begin{array}{l}-1.2 \\
(-1.3)\end{array}$ & $\begin{array}{l}1.4 \\
(3.3)\end{array}$ & $\begin{array}{l}-2.6 \\
(-3.2)\end{array}$ & $\begin{array}{l}1.9 \\
(3.2)\end{array}$ & $\begin{array}{l}0.2 \\
(1.0)\end{array}$ \\
\hline$Q_{Y}$ & $\begin{array}{l}0.05 \\
(0.2)\end{array}$ & $\begin{array}{l}0.3 \\
(2.1)\end{array}$ & $\begin{array}{l}-1.0 \\
(-4.1)\end{array}$ & $\begin{array}{l}0.9 \\
(5.4)\end{array}$ & $\begin{array}{l}0.3 \\
(1.8)\end{array}$ \\
\hline $\mathrm{C}_{\mathrm{X}}$ & $\begin{array}{l}-1.8 \\
(-2.0)\end{array}$ & $\begin{array}{l}3.0 \\
(6.8)\end{array}$ & $\begin{array}{l}-4.6 \\
(-5.8)\end{array}$ & $\begin{array}{l}2.8 \\
(4.6)\end{array}$ & $\begin{array}{l}0.05 \\
(0.5)\end{array}$ \\
\hline $\mathrm{C}_{\mathrm{Y}}$ & $\begin{array}{l}-0.2 \\
(-0.5)\end{array}$ & $\begin{array}{l}0.5 \\
(2.7)\end{array}$ & $\begin{array}{l}-1.1 \\
(-4.0)\end{array}$ & $\begin{array}{l}0.9 \\
(4.2)\end{array}$ & $\begin{array}{l}0.3 \\
(2.4)\end{array}$ \\
\hline $\mathrm{K}_{\mathrm{X}}$ & $\begin{array}{l}-0.01 \\
(-0.02)\end{array}$ & $\begin{array}{l}-0.2 \\
(-1.1)\end{array}$ & $\begin{array}{l}-0.1 \\
(-0.4)\end{array}$ & $\begin{array}{l}0.9 \\
(4.7)\end{array}$ & $\begin{array}{l}0.5 \\
(4.3)\end{array}$ \\
\hline $\mathrm{K}_{\mathrm{Y}}$ & $\begin{array}{l}0.3 \\
(0.9)\end{array}$ & $\begin{array}{l}-0.3 \\
(-2.4)\end{array}$ & $\begin{array}{l}-0.3 \\
(-1.1)\end{array}$ & $\begin{array}{l}0.6 \\
(2.8)\end{array}$ & $\begin{array}{l}0.6 \\
(3.4)\end{array}$ \\
\hline $\mathrm{L}_{\mathrm{X}}$ & $\begin{array}{l}-0.1 \\
(-0.2)\end{array}$ & $\begin{array}{l}0.3 \\
(2.6)\end{array}$ & $\begin{array}{l}-0.4 \\
(-1.9)\end{array}$ & $\begin{array}{l}0.5 \\
(2.5)\end{array}$ & $\begin{array}{c}0.7 \\
(5.3)\end{array}$ \\
\hline $\mathrm{L}_{Y}$ & $\begin{array}{l}0.2 \\
(0.9)\end{array}$ & $\begin{array}{l}0.05 \\
(0.6)\end{array}$ & $\begin{array}{l}-0.1 \\
(-0.5)\end{array}$ & $\begin{array}{l}0.2 \\
(1.8)\end{array}$ & $\begin{array}{l}0.6 \\
(3.1)\end{array}$ \\
\hline
\end{tabular}

Note: numbers in parentheses are t-statistics. 
Figure (1): Output of (X); Actual and fitted (Logs)

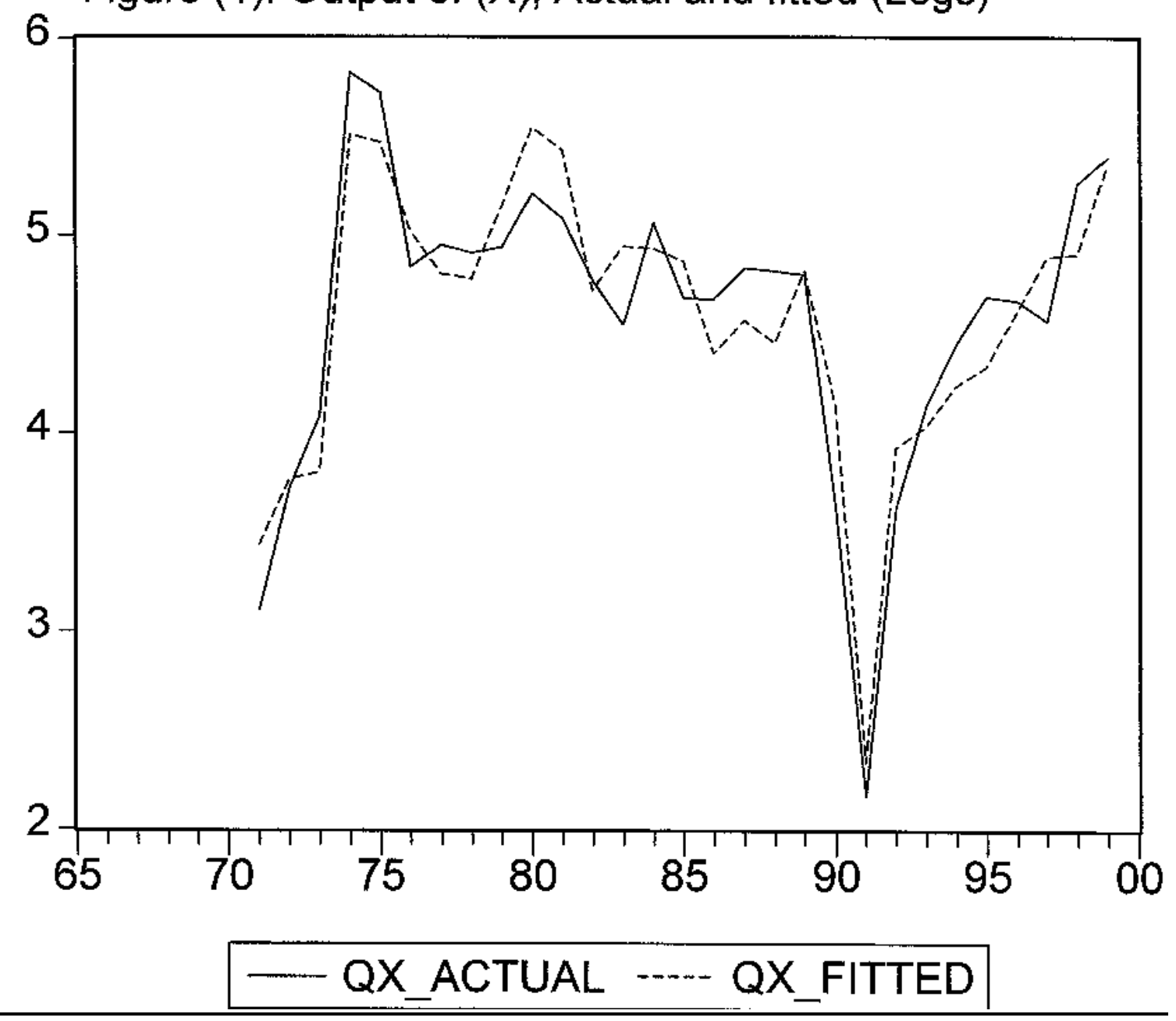


Figure (2): Output of $(Y)$; Actual and Fitted

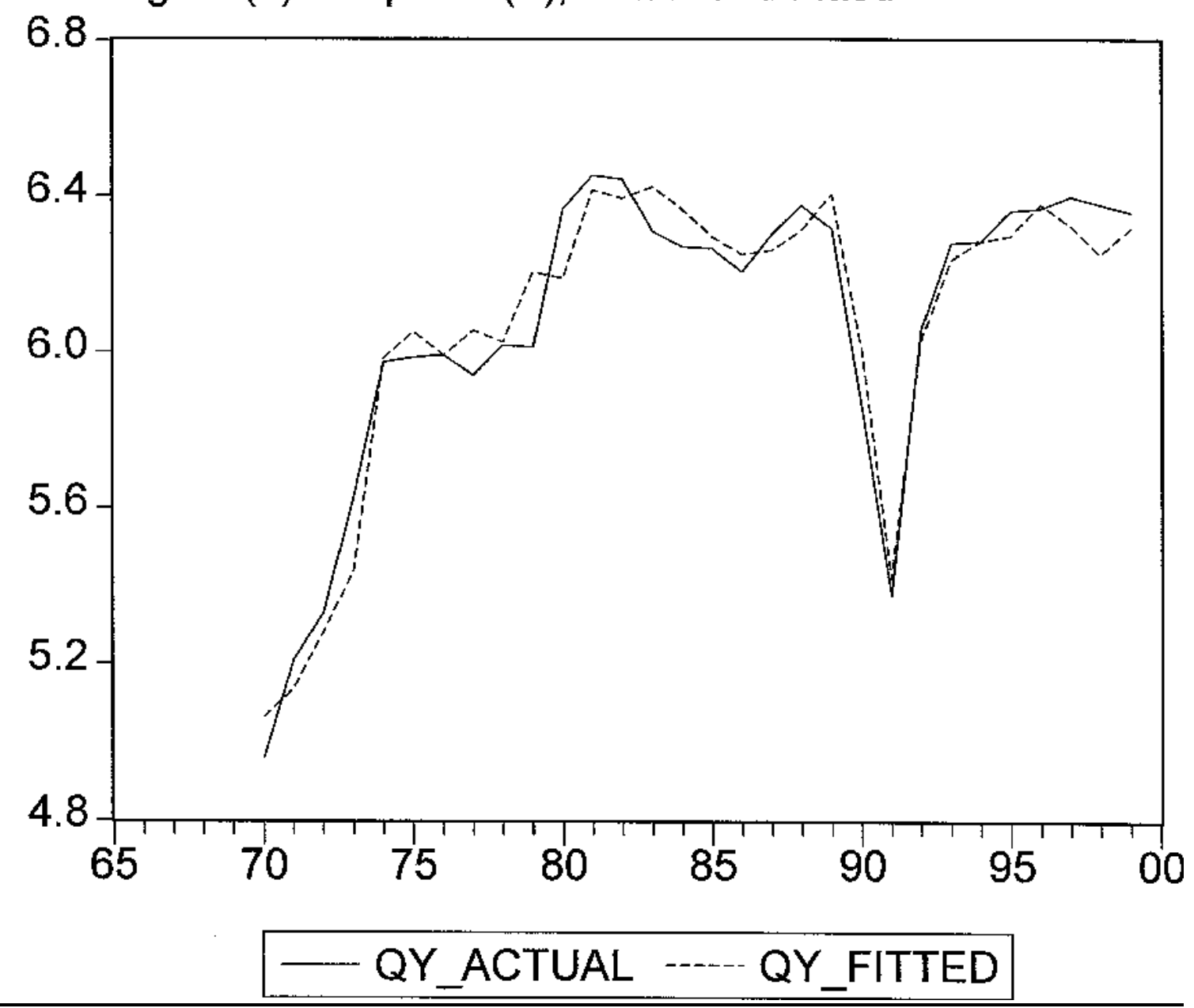




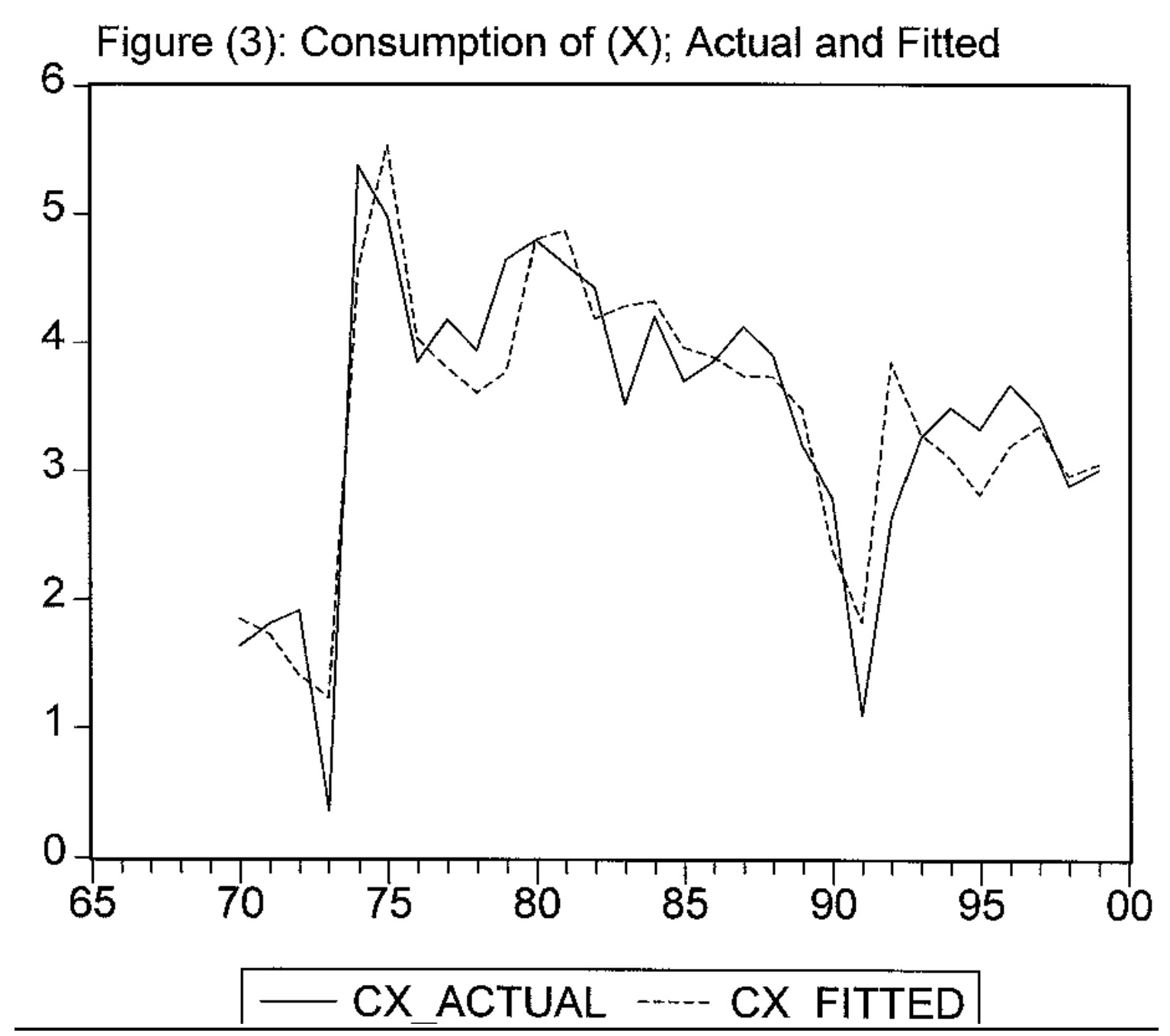


Figure(4): Consumption of $(\mathrm{Y})$; Actual and Fitted

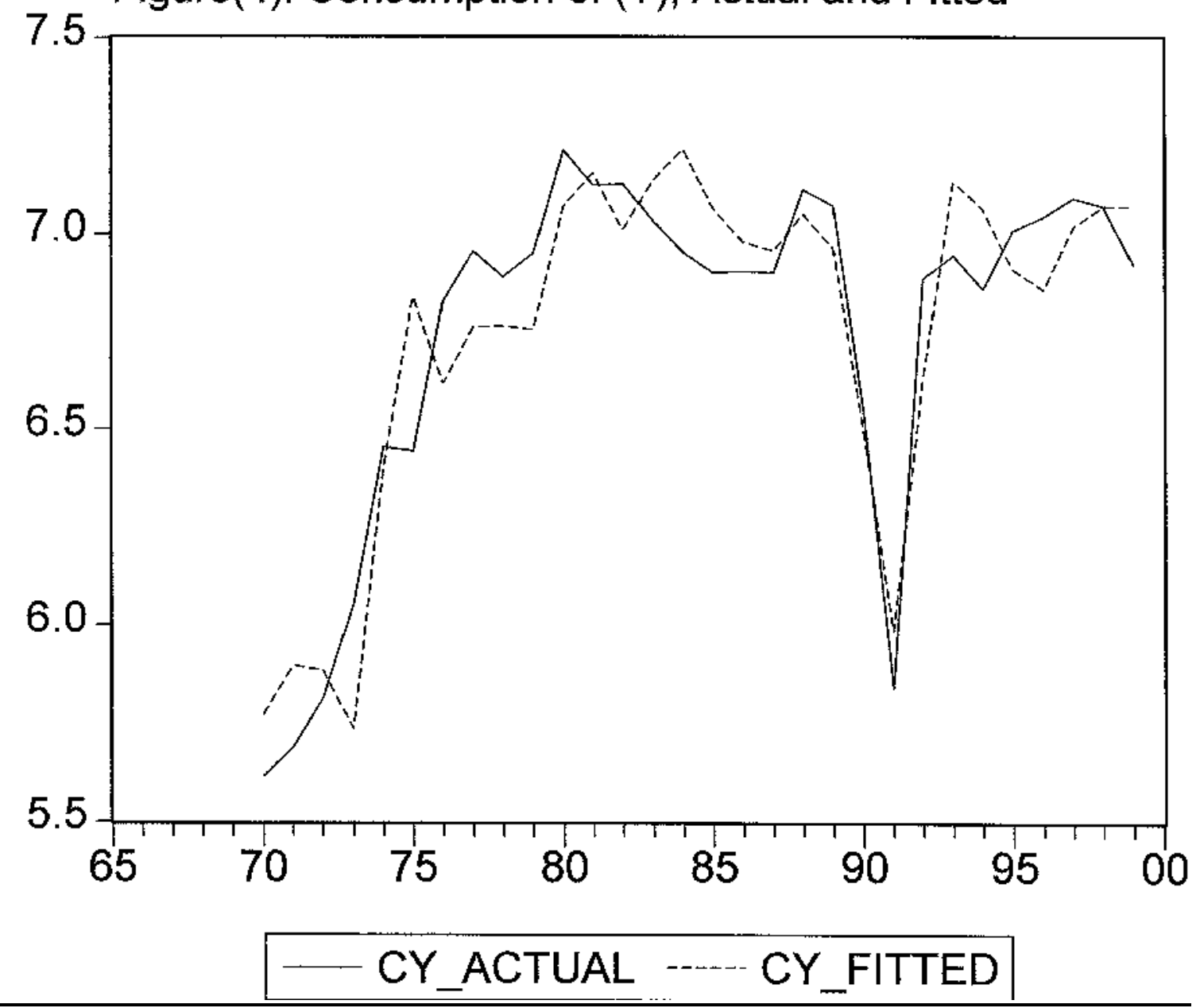


Figure (5): Demand for Capital in (X); Actual and Fitted

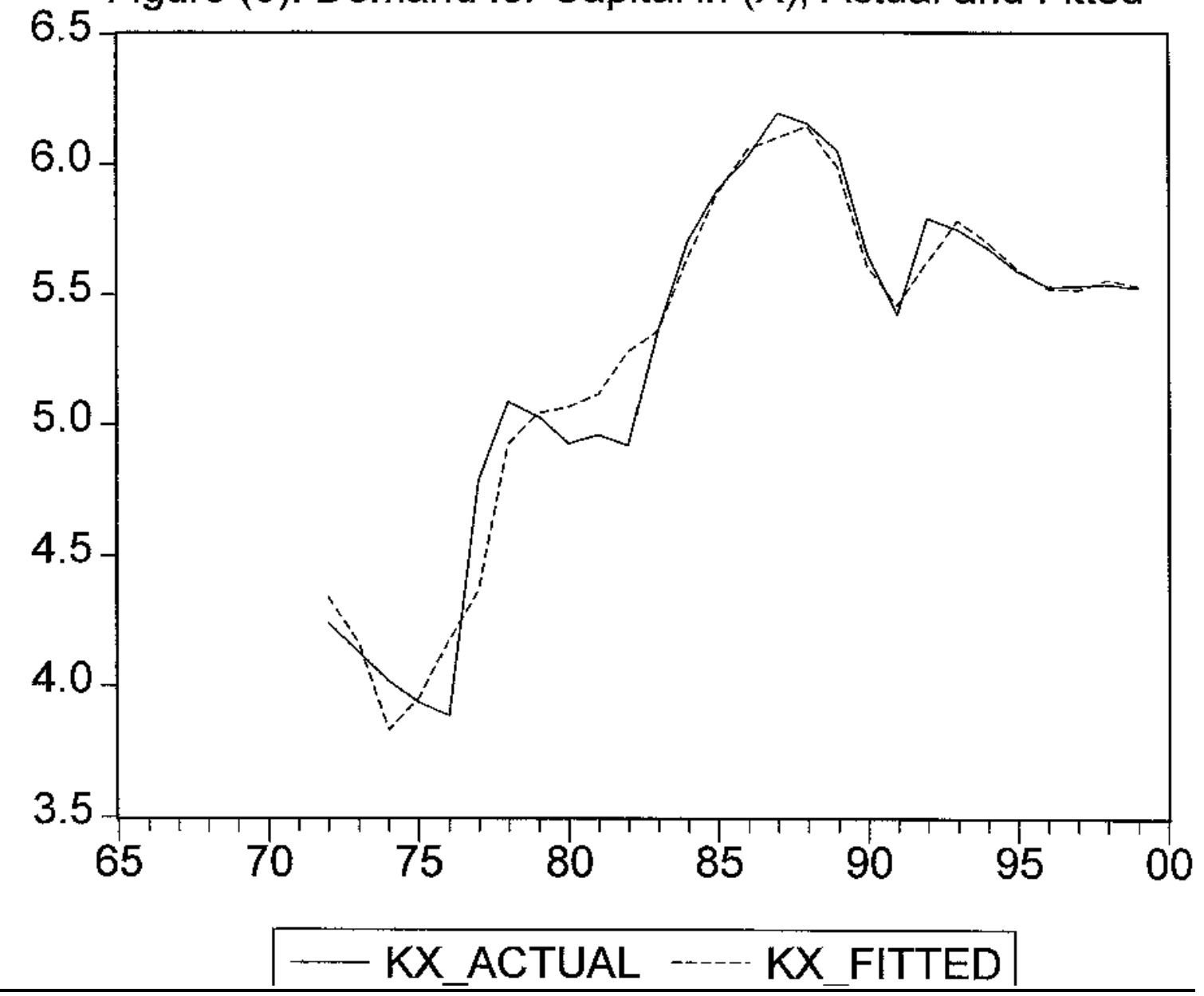


Figure (6): Demand for Capital in (Y); Actual and Fitted

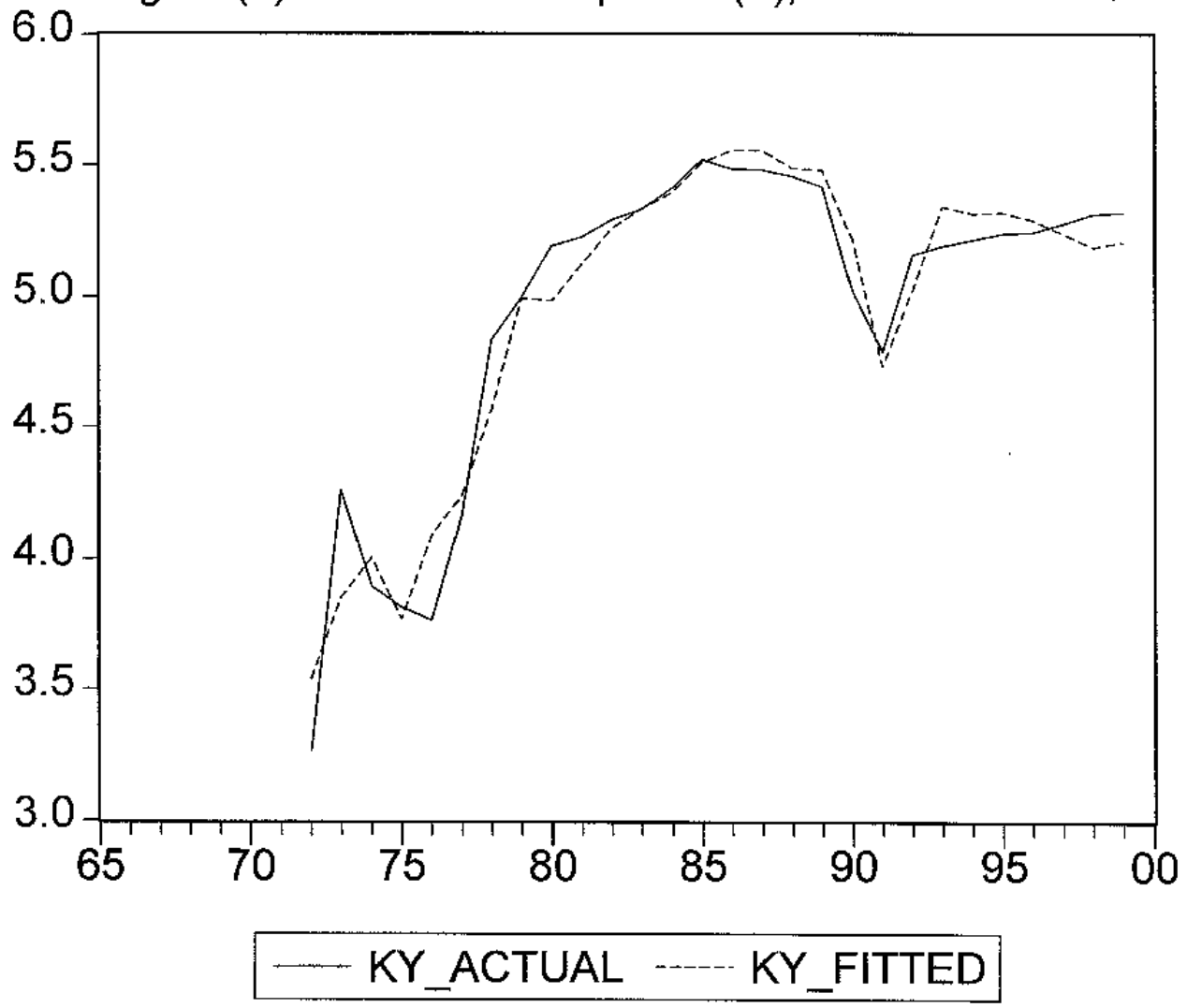


Figure (7): Demand for Labor in (X); Actual and Fitted

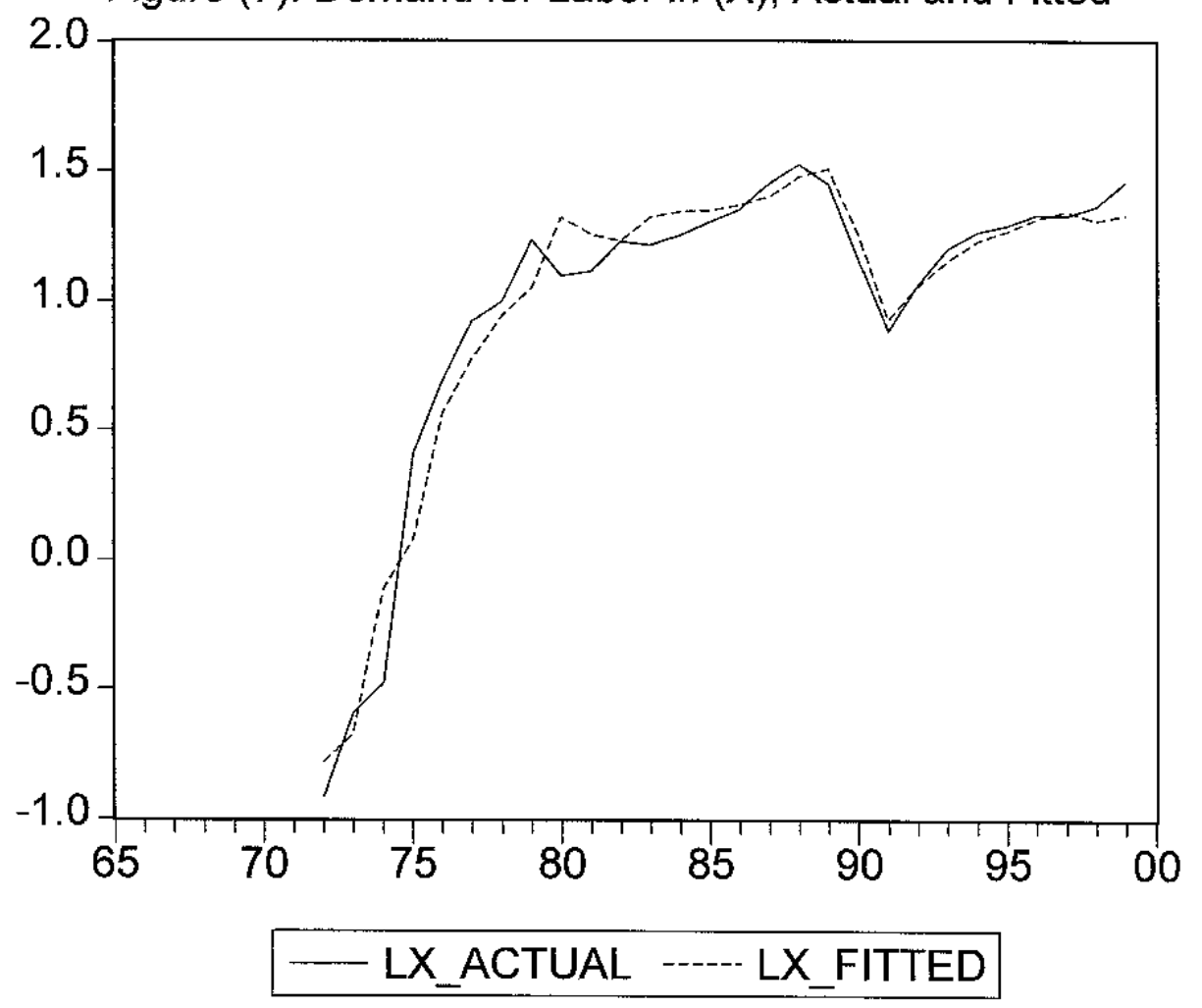


Figure (8): Demand for Labor in (Y); Actual and Fitted

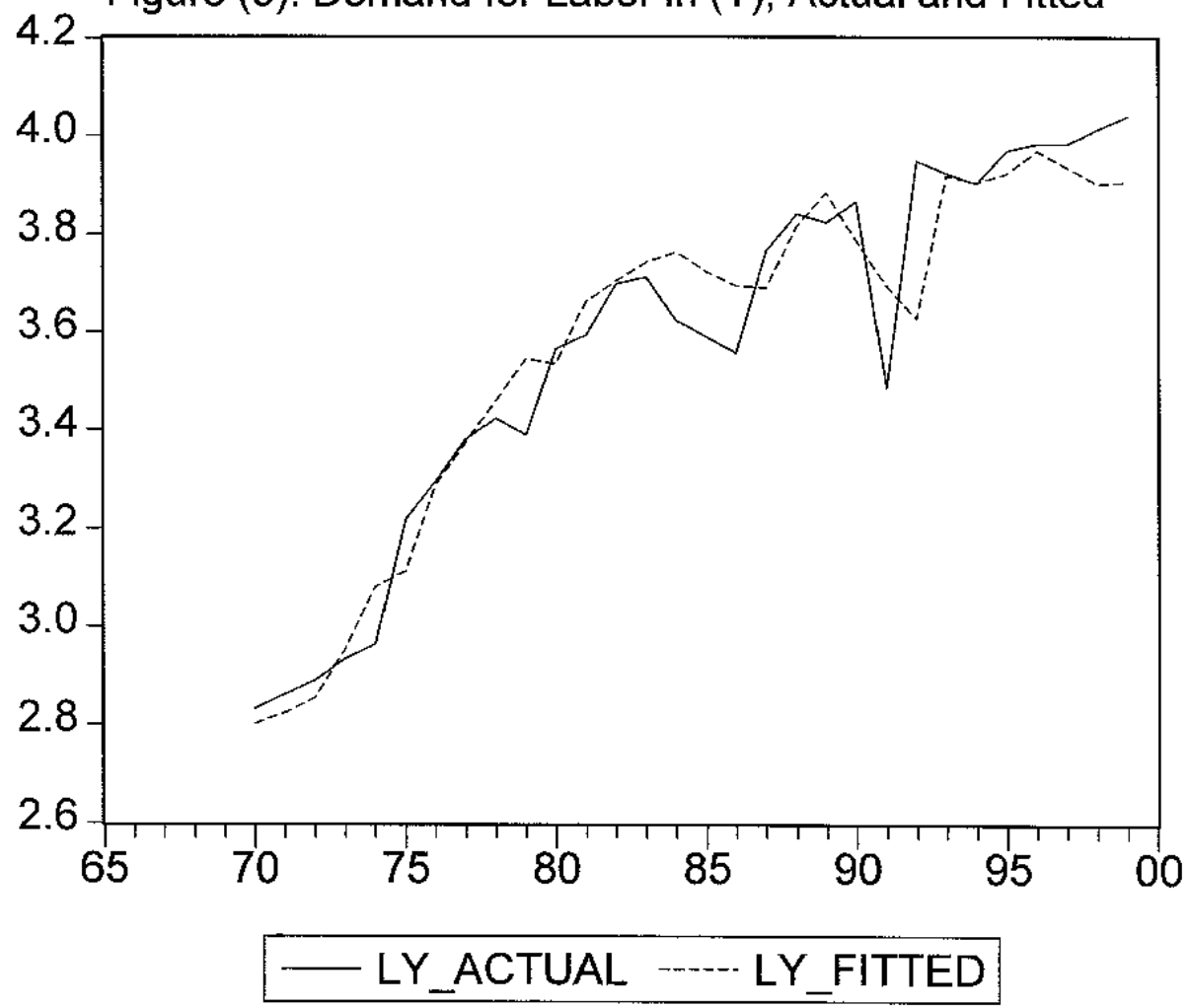


Figure (9): Output of (X); Baseline and With WTO

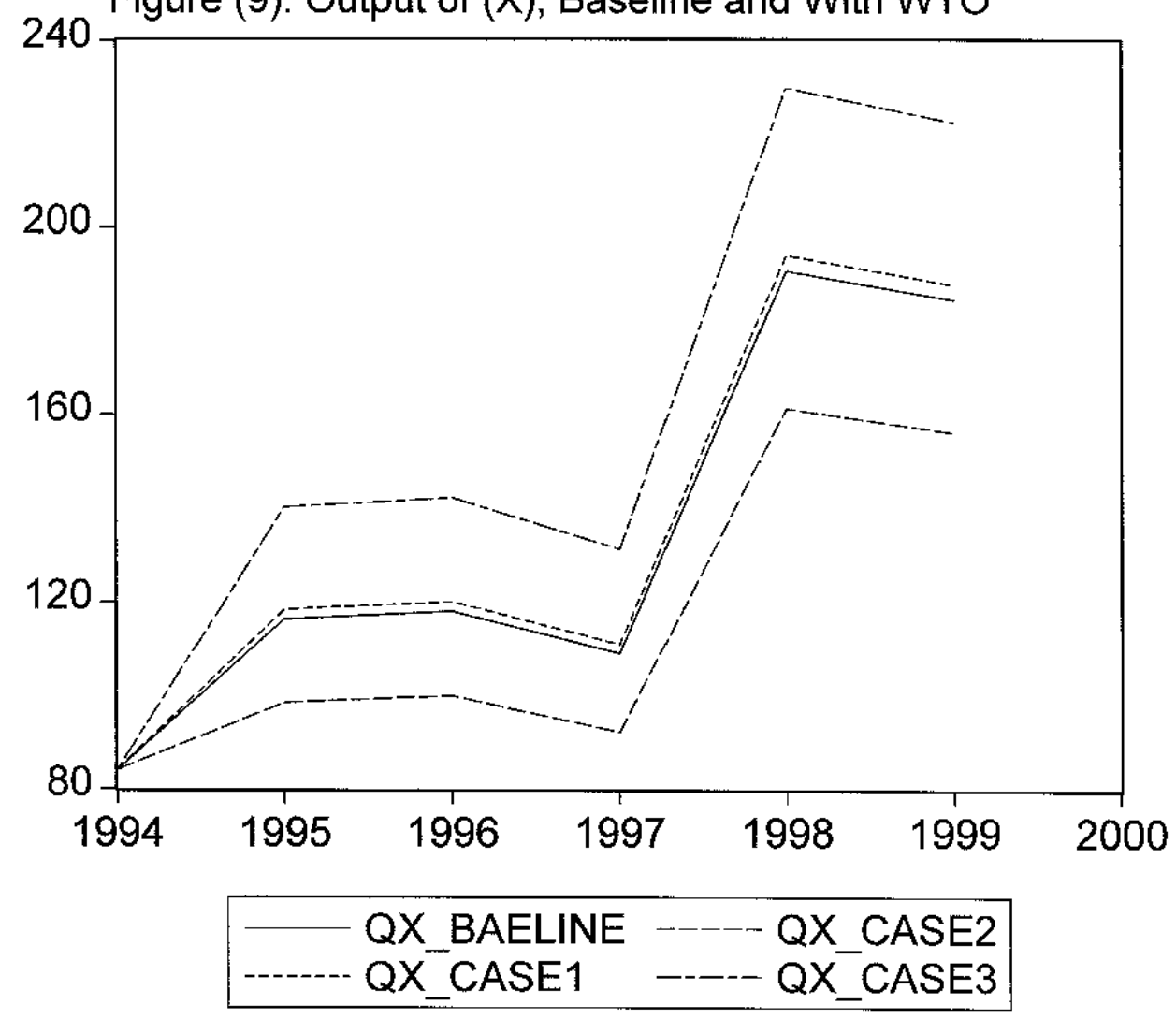




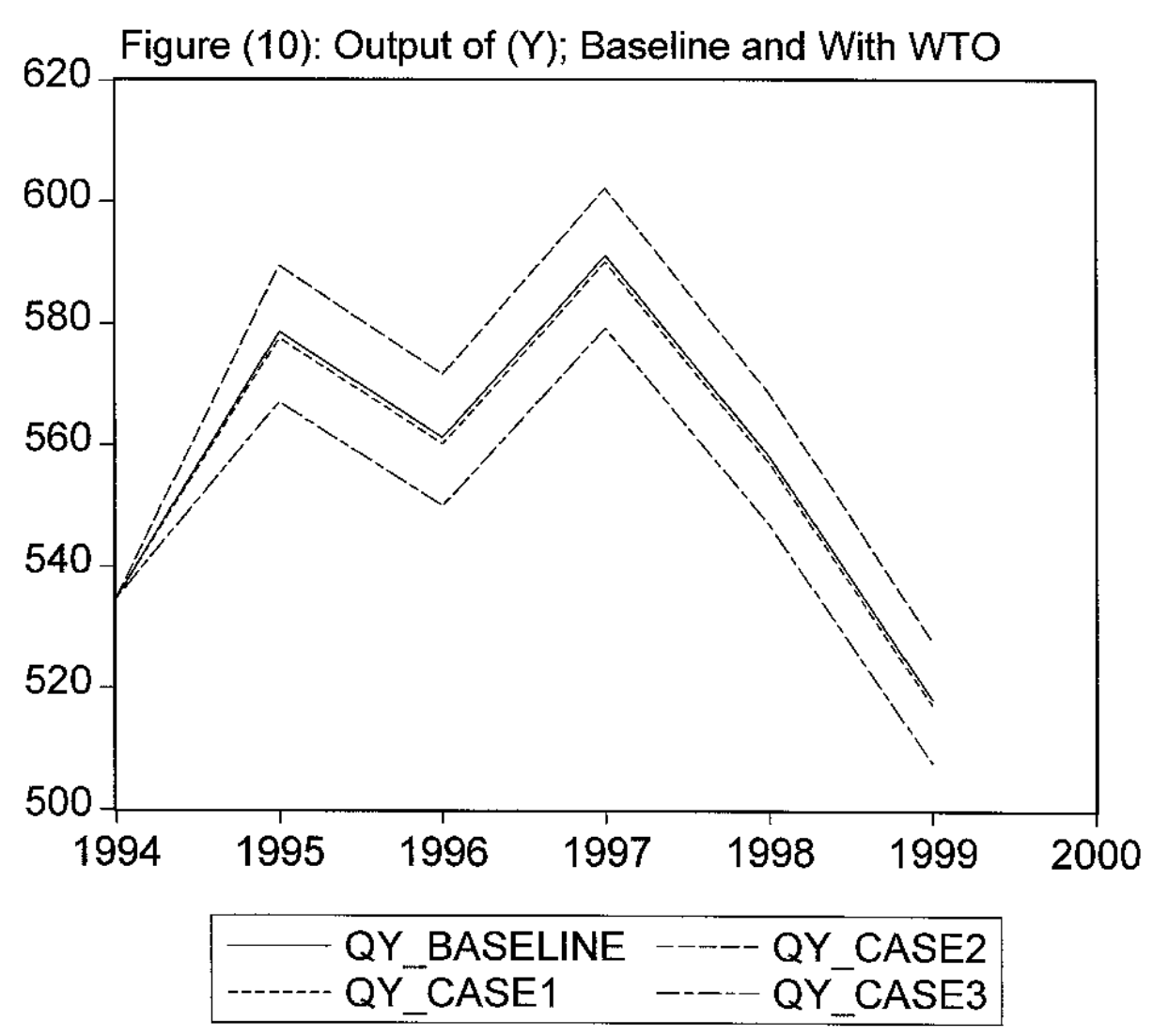




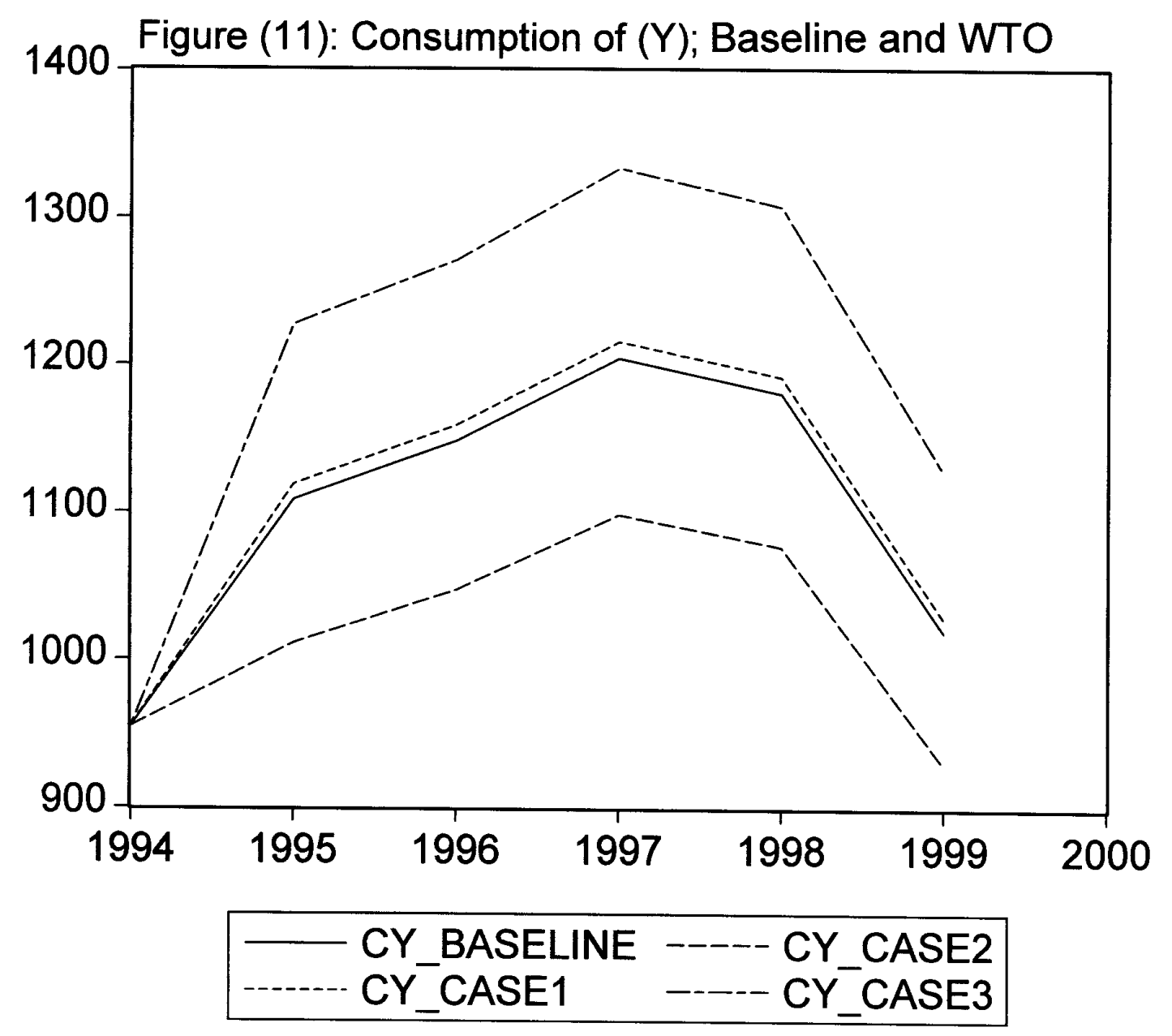




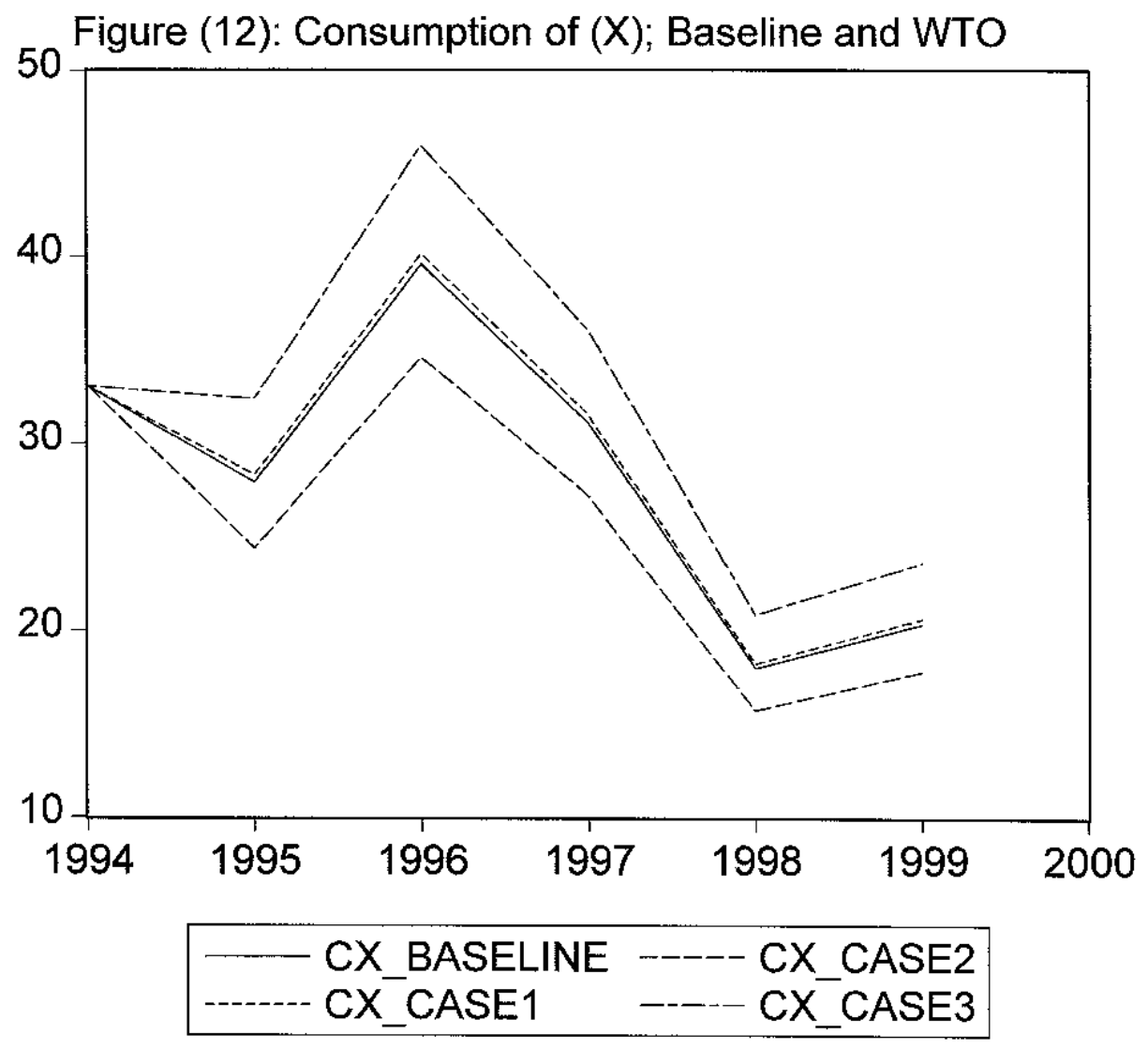




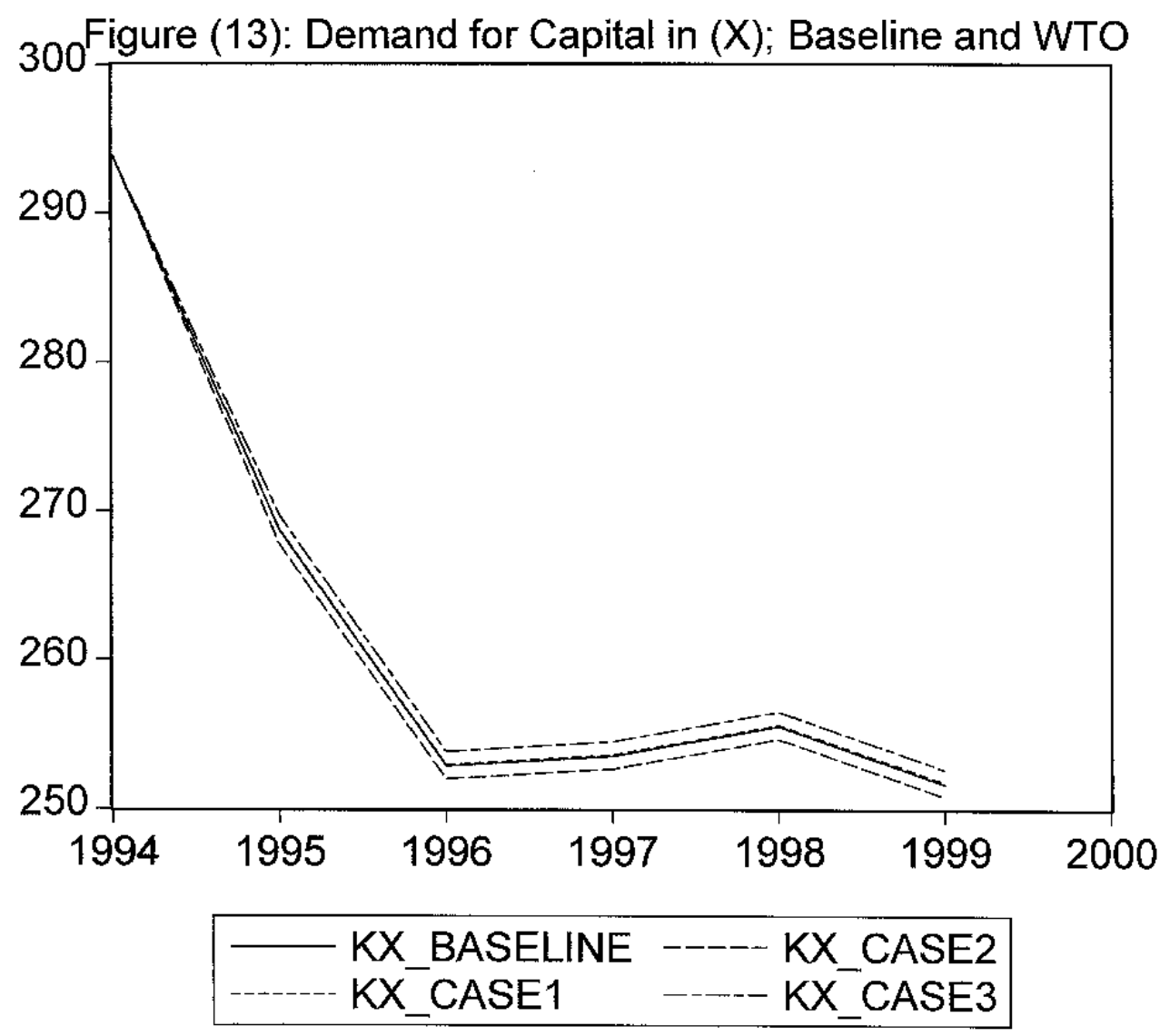




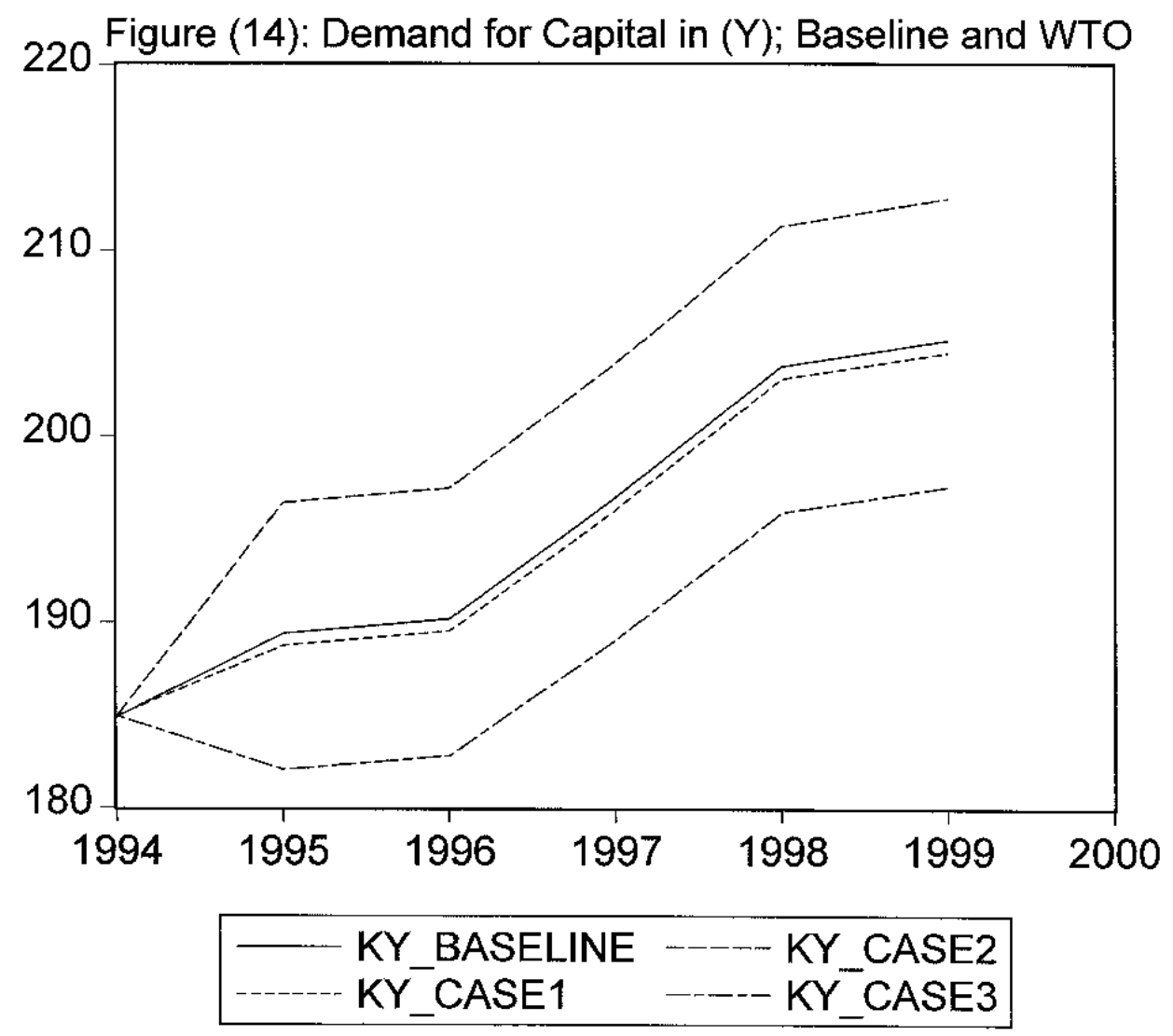




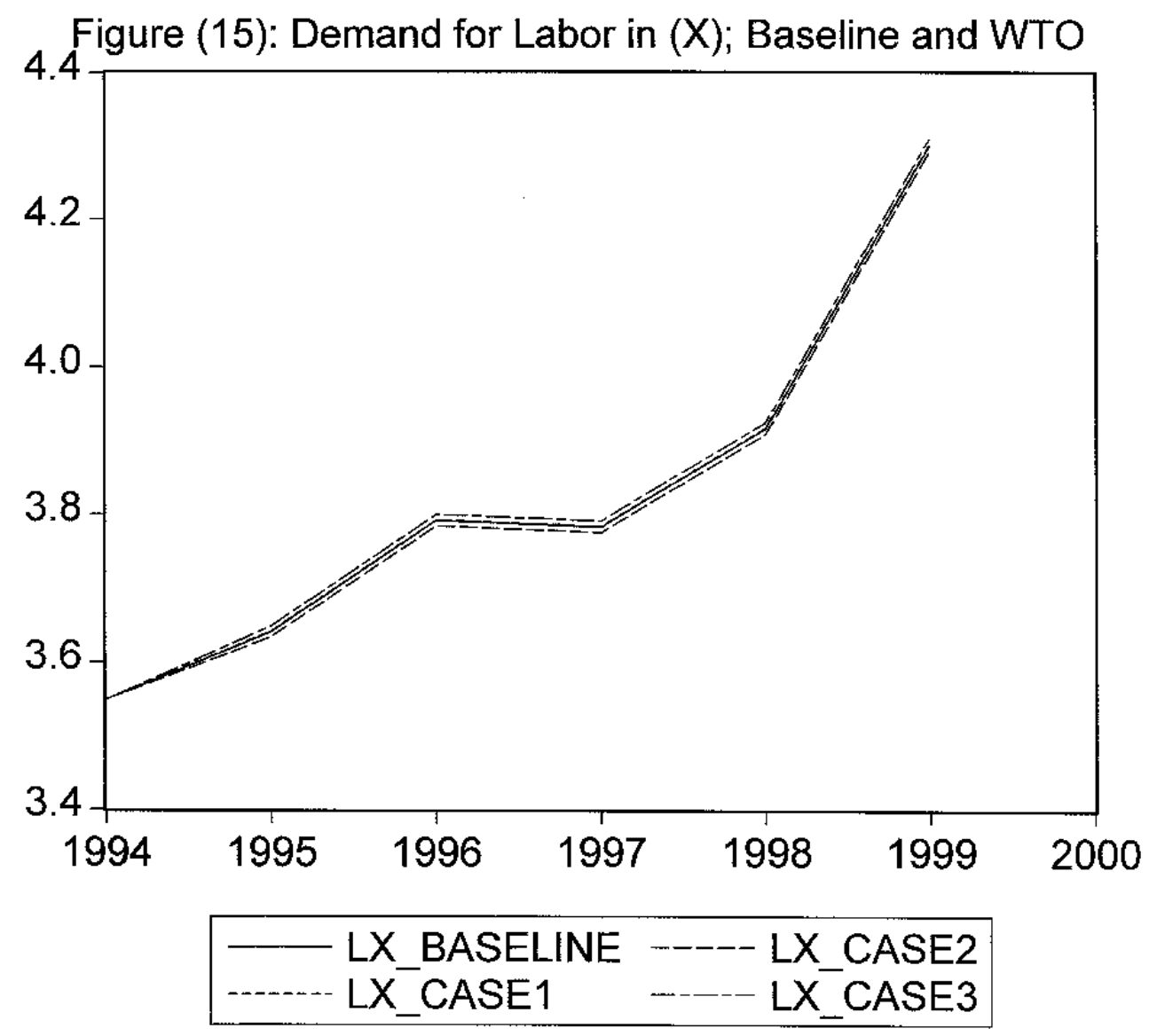




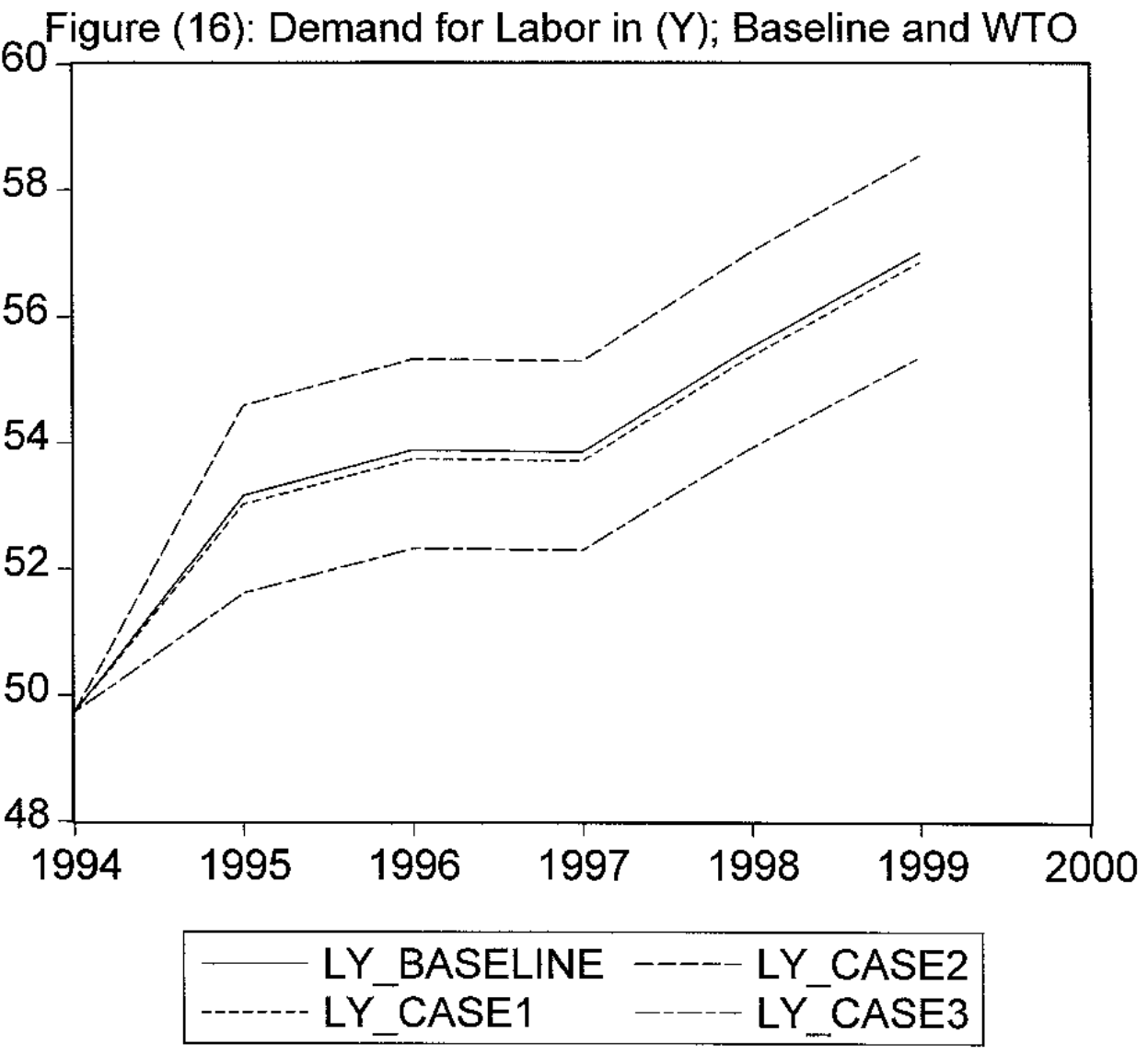


Figure (17): Imports of $(Y)$; Baseline and WTO

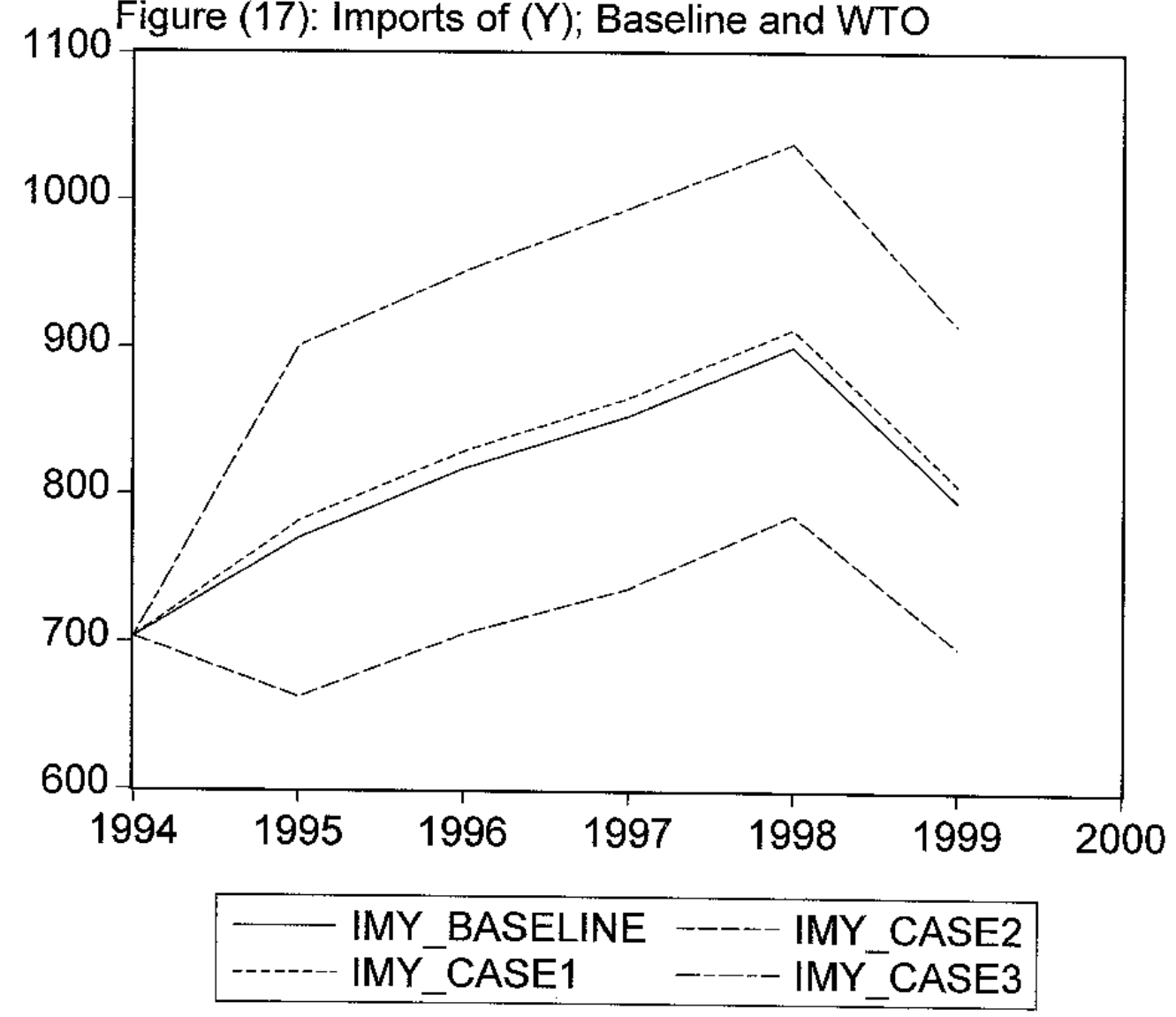


Figure (18): Exports of (X); Baseline and WTO

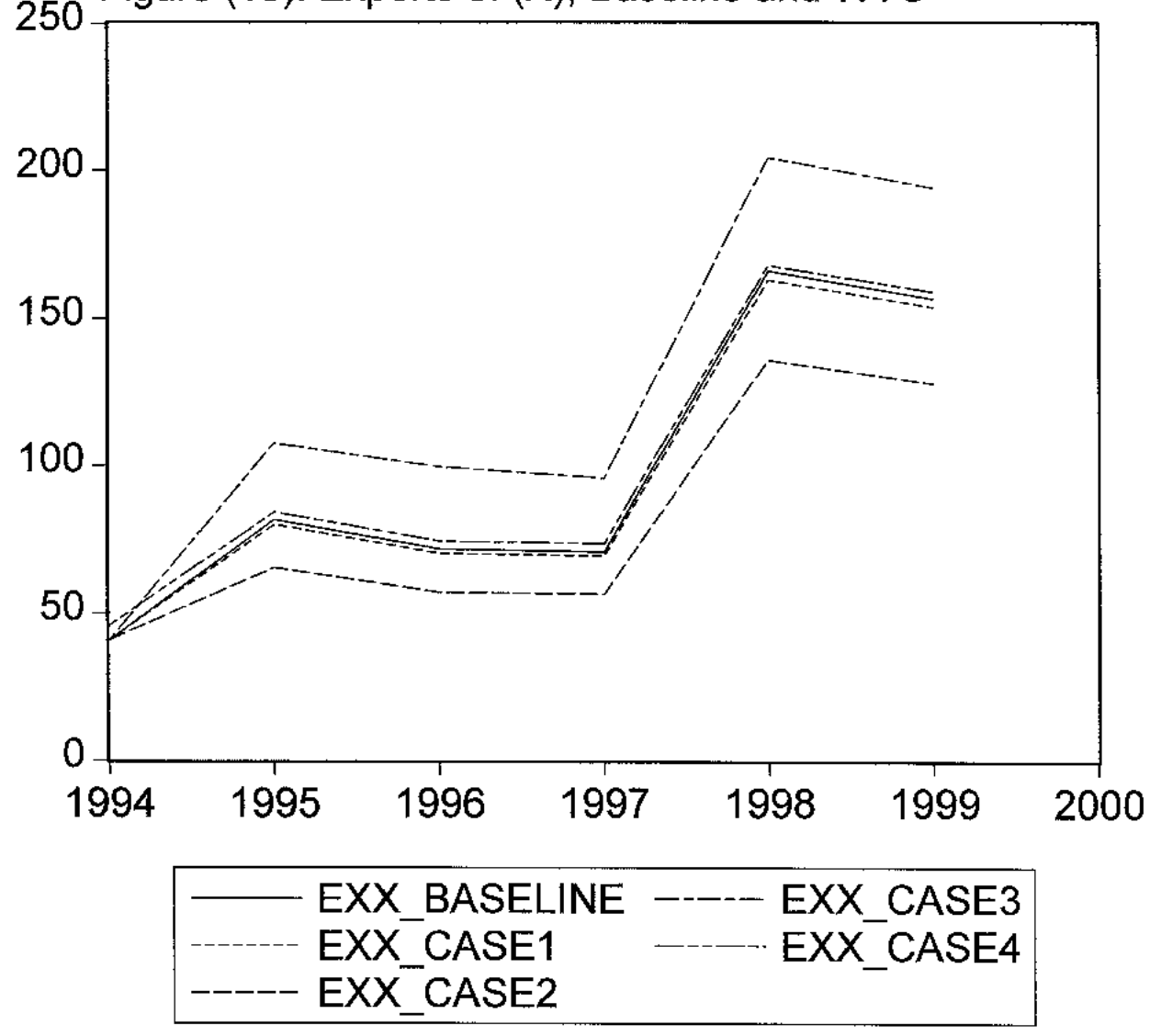

